UNIVERSIDADE DE COIMBRA

FACULDADE DE DIREITO

2ํㅡㄴ CICLO DE ESTUDOS EM DIREITO

\title{
IMUNIDADE DE JURISDIÇÃO DOS ESTADOS E DIREITOS HUMANOS \\ Uma crítica ao Caso Ferrini
}

Eliane Romeiro Fernandes Golin

Coimbra 
UNIVERSIDADE DE COIMBRA

FACULDADE DE DIREITO

2 ํ CICLO DE ESTUDOS EM DIREITO

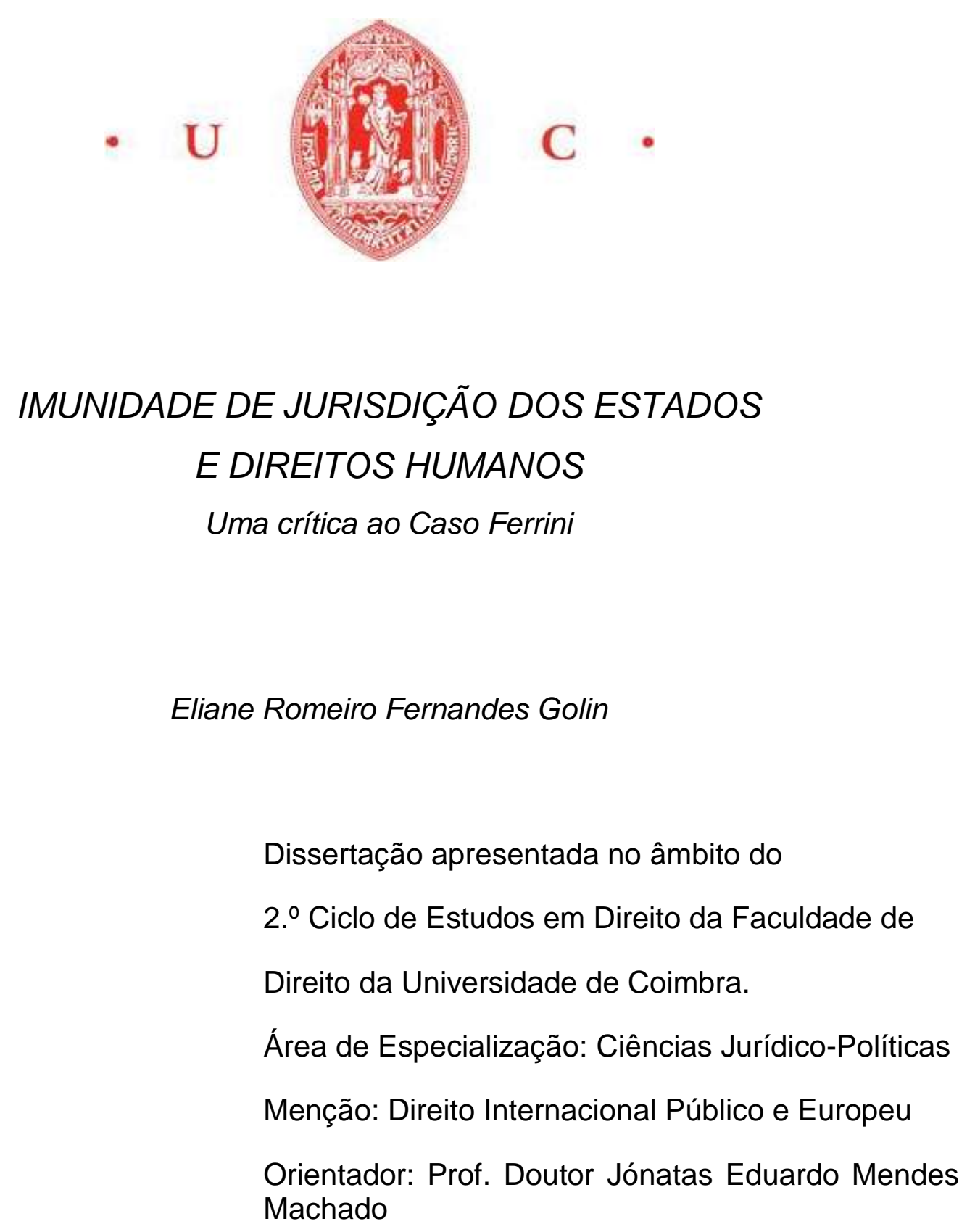

Machado

Coimbra 
ELIANE ROMEIRO FERNANDES GOLIN

\section{IMUNIDADE DE JURISDIÇÃO DOS ESTADOS E DIREITOS HUMANOS}

Uma crítica ao Caso Ferrini

Aprovado em:

BANCA EXAMINADORA 
A obra encontra-se redigida segundo as regras ortográficas e gramaticais vigentes no Brasil e de acordo com as normas técnicas da Associação Brasileira de Normas Técnicas (ABNT). 
Dedico este trabalho a você Raphael, companheiro no amor, na vida e nos sonhos, que sempre me apoiou nas horas difíceis e compartilhou comigo as alegrias. 


\section{AGRADECIMENTOS}

Agradeço primeiramente a DEUS, que foi meu maior porto seguro. Com a ajuda Dele eu tive forças para chegar ao final dessa jornada. Foi Ele quem me deu toda coragem que eu precisava para ir além dos meus limites nesta etapa da minha vida e não me deixou faltar forças para ir até o final e quebrar as barreiras.

A minha mãe Elva, responsável por cada sucesso obtido e cada degrau avançado pelo resto da minha vida. Durante todos esses anos você foi para mim um grande exemplo de força, de coragem, perseverança e energia infinita para nunca desistir diante do primeiro obstáculo encontrado, você é e sempre será meu maior porto seguro, meu maior exemplo de vitória, minha heroína e simplesmente aquela que mais amo. Obrigada por estar sempre comigo. Obrigada simplesmente por participar comigo durante essa caminhada, me ajudando a construir os alicerces de um futuro que começa agora, após anos dedicados a uma paixão que surgiu na infância. Você me ensinou direta e indiretamente lições pra toda uma vida.

A minha sogra lone e ao meu sogro Milton, pelo carinho, apoio e incentivo, por sempre terem torcido por mim, almejando pelo meu sucesso.

Ao Raphael agradeço pela paciência, pelo incentivo, pela força e principalmente pelo carinho. Valeu a pena toda distância, todo sofrimento, todas as renúncias. Valeu a pena esperar. Hoje estamos colhendo, juntos, os frutos do nosso empenho!

Aos meus queridos amigos Patrícia e Allan que sempre estiveram presente nos momentos em que precisei de uma mão amiga, me dando força e alegrando a minha caminhada.

Ao Senhor Professor Doutor Jónatas Eduardo Mendes Machado, meu orientador, pelos preciosos ensinamentos e pela inestimável contribuição para a realização deste trabalho e, indubitavelmente, pelo incentivo moral e pela liberdade proporcionada em sua realização. Obrigada por contribuir com tantos ensinamentos, tanto conhecimento, tantas palavras de força e ajuda. Carrego tudo isso comigo juntamente com seu exemplo de profissionalismo. 
"A essência dos Direitos Humanos é o direito a ter direitos"

(Hannah Arendt) 


\section{RESUMO}

O direito internacional passou por profundas alterações no último século. De uma perspectiva centrada na figura do Estado, passou-se a uma concepção que se preocupa cada vez mais com o papel do indivíduo, em um processo que se consolidou por intermédio do reconhecimento da importância dos direitos humanos. Atentar-se-á, precipuamente, sobre a influência de tal transformação na esfera da imunidade jurisdicional do Estado, que tem sido ultimamente contestada, também, quando as demandas que envolvem violações aos direitos humanos. Procurará analisar através da evolução do direito internacional o impacto das normas imperativas de direito internacional na esfera da imunidade jurisdicional do Estado. A principal questão que se descortina é: se a violação de uma norma jus cogens, ou seja, uma norma aceita e reconhecida pela comunidade internacional dos Estados em seu todo, como norma da qual nenhuma derrogação é permitida, não resultaria, mesmo, na perda de imunidade do Estado, como a jurisprudência no caso Ferrini afirma. Ademais, propõe-se demostrar, através de uma crítica ao Caso Ferrini, a necessidade de um novo paradigma no qual os direitos humanos devem prevalecer em detrimento da imunidade jurisdicional do Estado. Além de que, alvitrará que os Estados, que perpetrarem atos contrários às normas imperativas de direito internacional, não devem permanecer incólumes diante de tais atos ilícitos.

Palavras-chave: Imunidade Jurisdicional do Estado, violações de normas jus cogens, responsabilidade do Estado. 


\begin{abstract}
International law has undergone in profound changes over the last century. From the perspective centred in the figure of the State, it moved to a figure that is concerned more with the individual's role in a process which was consolidated through the recognition of the importance of human rights. Considering, mainly, that the influence of such a transformation in the sphere of State immunity, which has lately been challenged, too, as the demands involving human rights violations. Will attempt to examine, through the evolution of international law, the impact of peremptory norms of international law in the sphere of State immunity. The main question that unfolds is: if the violation of jus cogens norm, which means a norm accepted and recognized by the international community as a whole, as a norm from which no derogation is permitted, wouldn't truly result in the loss of the State immunity, as asserted in the Ferrini case law. Furthermore, it is proposed to demonstrate, through a critique of the Ferrini case law, the need for a new paradigm in which human rights must prevail over the rule of State immunity. Moreover, will put forward that that a State who perpetrates acts contrary to peremptory norms of international law, should not remain unscathed before such a wrongful act.
\end{abstract}

Keywords: Jurisdictional Immunity of State, violations of jus cogens norms, state responsibility. 


\section{SUMÁRIO}

INTRODUÇÃO

1 O IMPACTO DOS DIREITOS HUMANOS NA NOÇÃO DE SOBERANIA

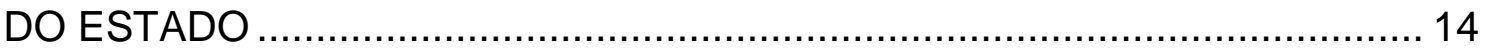

1.1 Constitucionalização do Direito Internacional..................................... 14

1.2 A Primazia do Indivíduo e dos Direitos Humanos .............................. 18

1.3 A Soberania como Responsabilidade ................................................ 24

2 RESPONSABILIDADE INTERNACIONAL DO ESTADO NO DOMÍNIO DO DIREITO INTERNACIONAL DOS DIREITOS HUMANOS ….......................... 29

2.1 A questão da Imputabilidade dos Estados ………............................. 35

2.2 Responsabilidade por Violações de Obrigações Internacionais........... 39

2.3 Direito à Reparação dos Indivíduos Vítimas de Violações Graves aos Direitos Humanos e de Direito Internacional Humanitário.............................. 44

2.3.1 O Dever do Estado de Prover Reparação aos Indivíduos Vítimas 44

3 IMUNIDADE DE JURISDIÇÃO DO ESTADO ……................................. 48

3.1 Conceituando Imunidade de Jurisdição ........................................... 48

3.2 Desenvolvimento Histórico da imunidade de Jurisdição do Estado

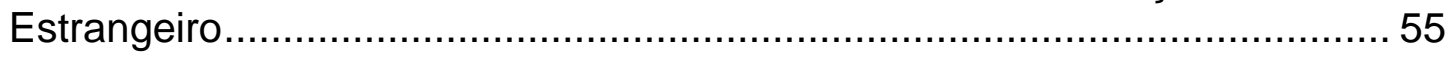

3.2.1 O advento da Imunidade de Jurisdição: a transposição do rei para

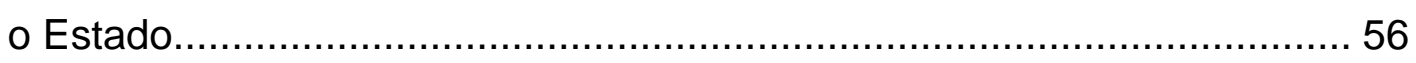

3.2.2 A Teoria Absoluta da Imunidade.............................................. 58

3.2.3 A Teoria Relativa da Imunidade ............................................... 61

3.3 A Convenção das Nações Unidas sobre Imunidade de Jurisdição dos Estados Estrangeiros e seus Bens ............................................................ 72

4 A IMUNIDADE DE JURISDIÇÃO DO ESTADO ESTRANGEIRO E AS VIOLAÇÕES AOS DIREITOS HUMANOS ................................................... 80 
4.1 Jurisdição Territorial

4.2 As normas peremptórias do Direito Internacional (jus cogens) podem afastar a aplicação da regra internacional consuetudinária relativa à imunidade de jurisdição? 84

4.3 A violação da imunidade como fato gerador de responsabilidade internacional...... 93

4.4 Caso Ferrini: Imunidades de Jurisdição do Estado (Alemanha v. Itália; Grécia intervindo) 96

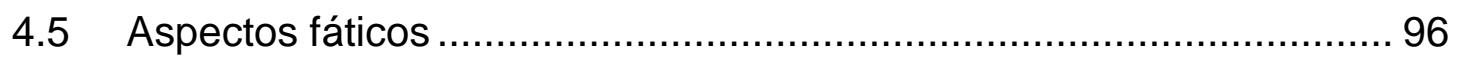

4.6 O caso no Tribunal Internacional de Justiça .................................... 100

4.6.1 Questão jurídica: Normas jus cogens v. imunidade de jurisdição101

4.6.2 A posição alemã .................................................................. 101

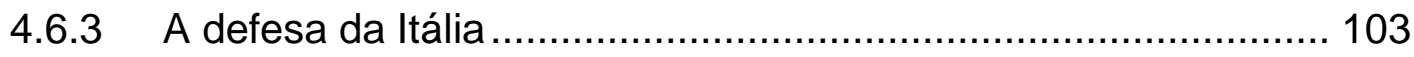

4.6.4 A intervenção da Grécia ....................................................... 105

4.7 Decisão e seus fundamentos .................................................... 108

4.8 Declarações de voto e votos de vencido .......................................... 111

4.9 Análise: o posicionamento doutrinal sobre a imunidade do Estado v. jus

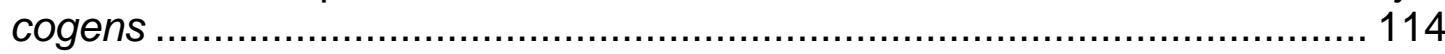

4.9.1 Argumentos Soberanistas ….............................................. 114

4.9.2 Argumentos humanistas .................................................. 118

4.9.2.1 A Teoria da Hierarquia Normativa ...................................... 118

4.9.2.2 A Teoria da "Cumplicidade"............................................... 121

4.9.2.3 A Teoria da "Qualificação"................................................ 122

4.9.2.4 A Teoria da "Renúncia implícita" ........................................ 123

4.9.2.5 A Teoria da "Jurisdição Universal" ...................................... 125

4.10 Discussão e tomada de posição ……………………………...... 127 
CONCLUSÕES

BIBLIOGRAFIA 


\section{INTRODUÇÃO}

O direito internacional passou por profundas alterações no último século. De uma perspectiva centrada na figura do Estado, passou-se a uma concepção que se preocupa cada vez mais com o papel do indivíduo, em um processo que se consolidou por intermédio do reconhecimento da acuidade dos direitos humanos. A primazia atribuída à proteção dos direitos humanos acarretou transformações em diversos institutos do direito internacional, cuja aplicação passou a se pautar também por estes valores.

Este estudo, portanto, irá abordar essencialmente 0 efeito de tais transformações sobre a imunidade jurisdicional do Estado estrangeiro, norma de origem ancestral cuja aplicação passou por um processo de limitação no último século e que, atualmente, tem sido contestada, também, quando as demandas que envolvem violações aos direitos humanos.

Em 23 de dezembro de 2008, a Alemanha recorreu ao Tribunal Internacional de Justiça alegando que a Itália, estaria ferindo a sua imunidade de jurisdição, ao julgar a República alemã em suas cortes civis por violações aos direitos humanos ocorridos na Segunda Guerra Mundial. O Tribunal Internacional de Justiça, em 3 de fevereiro de 2012, decidiu que, mesmo em casos de violações graves aos direitos humanos, um país não pode ser julgado pelo Judiciário de outro. Ainda nestes casos, a imunidade dos Estados prevalece.

O trabalho ora encetado, procura analisar através da evolução do direito internacional o impacto das normas imperativas de direito internacional na esfera da imunidade jurisdicional do Estado. Será que a violação de uma norma jus cogens, ou seja, uma norma aceita e reconhecida pela comunidade internacional dos Estados em seu todo, como norma da qual nenhuma derrogação é permitida não resultaria, mesmo, na perda de imunidade do Estado?

Para os fins deste estudo, a presente dissertação abordará em seu primeiro capítulo, o impacto dos direitos humanos na noção de soberania do Estado. 
Num segundo momento, tratar-se-á sobre a responsabilidade Internacional do Estado no domínio do Direito Internacional dos Direitos Humanos.

$\mathrm{Na}$ terceira parte, será elucidada a questão da imunidade de jurisdição, especificamente, e sua flexibilização no decorrer dos anos.

Por fim, o quarto e último capítulo desdobrar-se-á, especificamente, sobre imunidade de jurisdição do Estado estrangeiro em casos envolvendo violações aos direitos humanos. 


\section{O IMPACTO DOS DIREITOS HUMANOS NA NOÇÃO DE SOBERANIA DO ESTADO}

\subsection{Constitucionalização do Direito Internacional}

A Constitucionalização do Direito Internacional não é uma temática nova no Direito Internacional. 1 Tampouco é assunto suscetível de uma só interpretação, podendo receber inúmeros significados devido à polissemia do termo "constituição".

No presente trabalho ao tratarmos da constitucionalização do direito internacional, estaremos nos referindo ao "processo de desenvolvimento de um direito internacional objetivo, que vincula as relações entre os sujeitos do direito internacional". ${ }^{2}$

Tradicionalmente, o uso do termo constituição limitava-se as constituições domésticas. Como é cediço, as constituições nacionais que conhecemos hoje são frutos da filosofia jurídica dos séculos XVIII e XIX, criados com o escopo de facilitar a transição do feudalismo para o liberalismo. As constituições escritas foram empregadas como meio de limitar a interferência do Estado sobre os direitos e as liberdades privadas e de garantir a participação política dos cidadãos. ${ }^{3}$ Atualmente, as constituições nacionais apresentam um conjunto de preceitos fundamentais que regem a organização e o desempenho das atribuições governamentais em um determinado Estado, além de regularem as relações entre as autoridades dos Estados e seus cidadãos.

\footnotetext{
1 Para mais detalhes vide QUEIROZ, C. Direito Constitucional Internacional. Lisboa: Coimbra Editora, 2011. p. 17 et seq.

2 TRINDADE, O. C. A constitucionalização do Direito internacional: mito ou realidade? Revista de Informação Legislativa, Brasília, abr.jun. 2008. p. 271-272.

${ }^{3}$ Cf. WET, E. D. The international constitutional order. International \& COmparative Law Quarterly, v. 55, n. 1, p. 51-76, 2006; WALTER, C. Constituzionalizing (Inter)national Governance - Possibilities for and Limits to the development of an Intenational Constitutional Law. German Yearbook of International Law, v. 44, p. 170-201, 2001; FASSBENDER, B. The meaning of international constitutional law. In: TSAGOURIAS, N. Transnational constitutionalism: international and european models. Cambridge: Cambridge University Press, 2007. p. 307-328.
} 
Contudo, não há motivo para utilizar o termo "constituição" exclusivamente para designar a lei fundamental e suprema de um Estado soberano constituído por um único poder constituinte, uma vez que os Estados Federais, como a Alemanha, o Brasil e os Estados Unidos reconhecem as constituições subnacionais das suas unidades federativas. Mais importante ainda, no entanto, é o processo de constitucionalização no âmbito da União Europeia (UE), que resultou no Tratado que estabelece uma Constituição para a Europa. ${ }^{4}$ De acordo com Wet a elaboração da Constituição da União Europeia tem desafiado a noção de que uma ordem constitucional necessariamente implica na existência do demos constitucional tradicional. A arquitetura constitucional da Europa não foi validada mediante um processo de demos constitucional e vem de encontro a um dos requisitos clássicos de uma constituição, nomeadamente, a ligação intrínseca de uma Constituição e da Lei constitucional com o Estado e o povo. ${ }^{5}$ Diferentemente das constituições tradicionais, a constituição da União Europeia prevê a concorrência de politicas nacionais com uma ordem política maior, na forma de valores compartilhados e de organização política. ${ }^{6}$ Assim, prevê a coexistência de ordens constitucionais nacionais dentro de uma ordem constitucional supranacional, na figura da UE. De tal modo, "a Constituição europeia marca um momento inteiramente novo do constitucionalismo, no qual o homem tem a primazia sobre as teorias e as práticas até aqui adotadas". ${ }^{7}$

A discussão concernente à constitucionalização da Europa traz à baila a questão da transposição da noção de constitucionalismo abstrato à esfera pósnacional, com o intuito de adquirir controle sobre a tomada de decisões realizada

\footnotetext{
4 JORNAL OFICIAL DA UNIÃO EUROPEIA. Tratado que estabelece uma Constituição para a Europa. Comunicações e Informações. 2004/C 310/01.

${ }^{5}$ WET, E. D. The international constitutional order. International \& COmparative Law Quarterly, v. 55, n. 1, p. 52, 2006; KLABBERS, J.; PETERS, A.; ULFSTEIN, G. The constitutionalization of international law. New York: Oxford University Press, 2009. p. 19-25.
}

${ }^{6}$ MADURO, M. P. Europe and the constitution: what if this is a good as it gets? In: WEILER, J. H. H.; WIND, M. European constitutionalism: beyond the state. Cambridge: Cambridge University Press, 2003. p. 81-86.

${ }^{7}$ GOMES, P. P. J. Direito Constitucional em evolução: perspectivas. Curitiba: Juruá, 2005. p. 97. 
fora das fronteiras nacionais. ${ }^{8}$ Esta questão diz respeito à transposição das noções que vão desde valores humanistas neokantianos da democracia, responsabilidade, igualdade, a separação de poderes, o Estado de Direito e os direitos fundamentais. Em essência, os constitucionalistas europeus demonstraram como o constitucionalismo pode servir de referencial para um sistema normativo viável e legítimo para qualquer comunidade política, inclusive, em um cenário pós-nacional, ou seja, ordens constitucionais que são formadas além do Estado, que podem ser de natureza regional, internacional ou supranacional. ${ }^{9}$

De acordo com uma importante linha doutrinal, o desenvolvimento do direito internacional nas últimas décadas possibilita que este seja compreendido através da sintaxe, da semântica e da pragmática do direito constitucional. ${ }^{10} \mathrm{Um}$ dos advogados dessa teoria é Jürgen Habermas. Ao reexaminar a visão Kantiana de uma república mundial, este doutrinador delineou a estrutura de uma politica constitucional de uma sociedade mundial descentralizada como um sistema de governo multinível. Baseada em uma análise imparcial da situação mundial atual, o mesmo vislumbra um possível conceito de um sistema político multinível que, como um todo, não é um Estado, mas, no entanto, capaz de salvaguardar, sem um governo mundial, em um nível supranacional, a paz e os direitos humanos. e para solucionar a nível transnacional os problemas da "política doméstica global" (Welttinnenpolitik). ${ }^{11}$

\footnotetext{
8 WALKER, N. Postnational constitutionalism and the problem o translation. In: WEILER, J. H. H.; WIND, M. European constitutionalism: beyond the state. Cambridge: Cambridge University Press, 2003. p. 27-54.

9 WET, E. D. The international constitutional order. International \& COmparative Law Quarterly, v. 55 , n. 1, p. 52-53, 2006; WALKER, N. Postnational constitutionalism and the problem o translation. In: WEILER, J. H. H.; WIND, M. European constitutionalism: beyond the state. Cambridge: Cambridge University Press, 2003. p. 27-54. Cambridge: Cambridge University Press, 2003. p.34 et seq; MADURO, M. P. Europe and the constitution: what if this is a good as it gets? In: WEILER, J. H. H.; WIND, M. European constitutionalism: beyond the state. Cambridge: Cambridge University Press, 2003. p. 84 et seq.

10 WALTER, C. Constituzionalizing (Inter)national Governance - Possibilities for and Limits to the development of an Intenational Constitutional Law. German Yearbook of International Law, v. 44, p. 170-201, 2001; MACHADO, J. Direito internacional: do paradigma clássico ao pós-11 de Setembro. Coimbra: Coimbra Editora, 2006. p. 51.
}

11 HABERMAS, JÜRGEN. Der gaspaltene Westen. Apud FASSBENDER, B. The meaning of international constitutional law. In: TSAGOURIAS, N. Transnational constitutionalism: international and european models. Cambridge: Cambridge University Press, 2007. p. 314. 
Nas palavras de Gomes ${ }^{12}$ :

[...] o novo constitucionalismo é o da ética democrática justa e social, fundada nos princípios da participação pluralista, solidária e ativa, organizada para absorver e não para excluir pessoas, grupos e povos. É o constitucionalismo da ética da solidariedade de uma sociedade pluralista, poder-se-ia afirmar, a dizer, aquele que é libertador e organizador, promovendo uma arquitetura jurídica que propicie a união das pessoas e dos povos para resguardar a individualidade sem o individualismo e a identidade sem a segregação e isolacionismo de grupos. $O$ constitucionalismo contemporâneo expõe-se à abertura e ao intercambio e complementaridade com os outros ramos do conhecimento, como sejam, a política, a bioética, dentre outros. Não faz, assim, uma interseção do Direito, como antes pretendeu, mas a sua integração com os ramos do conhecimento humano que sejam pertinentes aos tema de seus cuidados.

Nesse diapasão, a teoria da constitucionalização do direito internacional parte da premissa de que a consolidação de uma comunidade internacional detentora de valores fundamentais, que originam normas jurídicas consagradoras de obrigações erga omnes ${ }^{13}$, assim como, a sua codificação em termos quase constitucionais, são necessárias e urgentes. Jónatas Machado, sabiamente ensina que "a comunidade internacional apresenta-se, cada vez mais, como comunidade constitucional, ao passo que o direito internacional assume uma função constitucional, em contraponto à dimensão parcial assumida com intensidade crescente pelo constitucionalismo nacional". ${ }^{14}$ Num tal contexto, retoma-se o ideal Kantiano de uma ordem constitucional cosmopolita interestadual. ${ }^{15}$

Apesar da inexistência de um poder constituinte formal à escala global, ele é incutido a partir de valores compartilhados por um número significativo de constituições estaduais ao redor do mundo. A partir do momento em que um conjunto crescente de povos aderem, em sede constituinte, os preceitos dos direitos humanos, da democracia, do Estado de direito, da resolução pacífica dos conflitos, do desenvolvimento social, etc., para conduzirem a vida dentro de suas fronteiras,

12 GOMES, P. P. J. Direito Constitucional em evolução: perspectivas. Curitiba: Juruá, 2005. p. 96

13 FASSBENDER, B. The meaning of international constitutional law. In: TSAGOURIAS, N. Transnational constitutionalism: international and european models. Cambridge: Cambridge University Press, 2007. p.315-321

${ }^{14}$ MACHADO, J. Direito internacional: do paradigma clássico ao pós-11 de Setembro. Coimbra: Coimbra Editora, 2006. p. 51

${ }^{15} \mathrm{KANT}$, I. A paz perpértua e outros opúsculos. Lisboa: Edições 70, 2009. 
pode-se concluir que os mesmos povos objetivam que as suas relações internacionais se subordinem àqueles valores, conferindo-lhes uma função materialmente constituinte de direito internacional. ${ }^{16}$

Os valores supracitados são a representação dos interesses gerais da comunidade internacional, da crescente dependência mútua dos Estados e da busca do bem comum internacional, impondo uma significativa transformação e mudança de conceitos jurídico-internacionais tradicionais, nomeadamente, de Estado, soberania, tratado internacional, dentre outros, e edificando uma ordem constitucional internacional, "conformada por uma noção de estadualidade aberta e interdependente, acompanhada da estruturação hierárquico-normativo do ordenamento jurídico internacional e do primado do respectivo direito constitucional." 17 Os âmbitos em que este fenômeno se dá com maior intensidade são os dos direitos humanos, a paz e a segurança internacionais, a organização da economia e do comércio internacional e a proteção dos espaços interacionais e do meio ambiente.

A constitucionalização do direito internacional é considerada como a mudança estrutural do direito internacional mais significativa das últimas décadas. Entretanto, é imperioso enaltecer que a sua negação por parte de muitos Estados perdurará, rejeitando a sobre interpretação dos tratados internacionais vigentes. ${ }^{18}$

\subsection{A Primazia do Indivíduo e dos Direitos Humanos}

Antes da criação da Organização das Nações Unidas, em 1945, a proteção dos direitos humanos e liberdades fundamentais era assunto essencialmente do direito interno dos Estados ${ }^{19}$.

\footnotetext{
${ }^{16}$ MACHADO, J. Direito internacional: do paradigma clássico ao pós-11 de Setembro. Coimbra: Coimbra Editora, 2006. p. 51-52

17 Ibidem, p. 52

18 Ibidem, p. 52

${ }^{19} \mathrm{O}$ termo essencialmente é utilizado nessa frase porque já naquela época o direito internacional se preocupou em proibir a prática tão odiosa e degradante como a escravidão (Congresso de Viena 1815), e admitiu, em contrapartida, as chamadas intervenções em razão da humanidade.
} 
Neste sentido, Henkin elucida que "historicamente, a forma pela qual um Estado trata o indivíduo em seu território era assunto de seu interesse exclusivo, decorrente de sua soberania relativamente ao seu território e da liberdade de agir". ${ }^{20} \mathrm{E}$, o fundamento para tal costume se dava pelo uso indiscriminado do discurso da manutenção de suas sob eranias, que no conceito clássico é a tradução do poder absoluto e perpétuo do Estado, podendo ser compreendida como a prerrogativa que possui o Estado de conduzir em suas fronteiras, definindo, assim, o próprio destino de seus nacionais, seja ditando comportamentos, infligindo sanções; em fim, desempenhando a sua jurisdição doméstica, refletindo a imagem de uma fortificação medieval praticamente inexpugnável. Desse modo, a soberania atribuía aos Estados um domínio reservado, que era invocado em detrimento de qualquer ato de ingerência, mesmo que em sede de proteção de seus nacionais.

Não obstante, há que se assinalar certa modificação no quadro acima elucidado avistando ainda na era moderna, o advento dos direitos humanos no pensamento filosófico ocidental do século XVII, operando como uma teoria abstrata, cuja força se sintetiza nas exigências formuladas ao poder público, que se encontrava constituído, buscando estabelecer limites aos atos dos governantes, reagindo contra o Estado absolutista que não reconhecia a separação entre o poder público e o privado, e, contestando os atos do soberano que ao instituir as leis não se sente sujeito a observá-las. ${ }^{21}$

Acerca da percepção no momento histórico, onde ocorreram as maiores progressões no sentido de se ter ações efetivas na esfera da proteção dos direitos humanos, Hélio Bicudo ensina que "[...] ainda que a proteção dos direitos humanos conhecesse desde a cidade antiga antecedentes notáveis; sua história não se desenvolve verdadeiramente senão com o Estado moderno, que reflete fundamentalmente as novas compreensões das relações entre o indivíduo e o poder". ${ }^{22}$

\footnotetext{
20 HENKIN apud PIOVESAN, F. Direitos Humanos e o Direito Constitucional Internacional. São Paulo: Saraiva, 2010. p. 120.

${ }^{21}$ AMARAL JÚNIOR, A. D. Curso de Direito Internacional Público. 2. ed. São Paulo: Atlas, 2011. p. 476.

22 BICUDO, H. Direitos Humanos e sua proteção. São Paulo: FDT, 1997. p. 32.
} 
Nesse mesmo sentido, Jónatas Machado entende que "embora os fundamentos remotos dos direitos fundamentais, de natureza civil política e econômica, social e cultural, possam ser encontrados em boa medida, nas tradições greco-romana e judaico-cristã, a atual consideração do indivíduo como sujeito de direito internacional é o resultado de um longo processo histórico que vai buscar os seus antecedentes à tradição de direito natural, à Reforma e à Paz de Vestefália". ${ }^{23}$

A corroborar o exposto, o reconhecimento dos direitos humanos, semelhante ao que se tem atualmente, tornou-se possível unicamente após um longo trabalho preparatório, centrado em torno da limitação do poder político e no reconhecimento de que os governados têm prevalência em detrimento dos governantes. ${ }^{24}$

Contudo, somente a partir do século XVIII surgem textos declarativos de direitos no sentido moderno, com especial mérito para a Declaração de Independência dos Estados Unidos da América (1776) e a Declaração dos Direitos do Homem e do Cidadão adotada pela Assembleia Constituinte francesa de 1789. ${ }^{25}$

Nas palavras de Fábio Konder Comparato: "As declarações de direito norteamericanas, juntamente com a Declaração francesa de 1789, representaram a emancipação histórica do indivíduo perante os grupos sociais aos quais ele sempre se submeteu: a família, o clã, o estamento, as organizações religiosas".

A passagem histórica ocorrida em 26 de agosto de 1789 assinala o momento a partir do qual surge a mais importante e famosa declaração de direitos fundamentais, a Declaração dos Direitos do Homem e do Cidadão, marcada em sua essência pela universalidade dos direitos inaugurados, e que firma solenemente que "a sociedade em que não esteja assegurada a garantia dos direitos fundamentais nem estabelecia a separação dos poderes não tem Constituição". ${ }^{26}$

\footnotetext{
${ }^{23}$ MACHADO, J. Direito internacional: do paradigma clássico ao pós-11 de Setembro. Coimbra: Coimbra Editora, 2006. p. 361-362.

${ }^{24}$ COMPARATO, F. K. A afirmação histórica dos direitos humanos. 6. ed. São Paulo: Saraiva, 2008. p. 41.

${ }^{25}$ Para mais detalhes vide LUÑO PÉREZ, A. E. Temas clave de la Constitucion Espanõla: Los derechos fundamentales. 5. ed. Madrid: Tecnos, 1993. p. 35-38.
}

26 ASSEMBLEIA NACIONAL DA FRANÇA. Declaração de Direitos do Homem e do Cidadão. França, 26 de agosto de 1789. Artigo 16. 
Esse evento histórico é marcante, pois não apenas utopicamente, como também legalmente, o homem passa a ser visto como detentor de direitos, e não unicamente de deveres. A partir desse momento, o Estado absolutista deixa de ser o sujeito exclusivo de direitos na seara internacional. Podendo-se arrazoar, inclusive, que com tal marco dá-se o primeiro passo para a legitimação dos anseios populares, e para uma limitação do poder soberano do Estado.

De acordo com José Afonso Silva: "o texto da declaração de 1789 é de estilo lapidar, elegante, sintético, preciso e escorreito, que, em dezessete artigos, proclama os princípios da liberdade, da igualdade, da propriedade e as garantias individuais liberais que ainda se encontram nas Declarações contemporâneas, salva as liberdades de reunião e de associação que ela desconhecia, firmando que estava em uma rigorosa concepção individualista". ${ }^{27}$

Ao analisar a teoria individualista, Norberto Bobbio chega à conclusão de que esta teoria desempenhou função de grande relevância ao colocar o indivíduo singular, com valor em si mesmo, em primeiro plano, ajeitando o Estado em uma posição secundária. Deste modo, o Estado seria feita pelo indivíduo, e não feita pelo Estado. ${ }^{28}$

Com base nessa inovação, Luigi Ferrajoli afirma que "com a Declaração dos Direitos do Homem e do Cidadão, de 1789, e depois coma as sucessivas cartas constitucionais, muda a forma do Estado, e, com ela muda, até se esvaziar, o próprio princípio da soberania interna". ${ }^{29}$

O doutrinador italiano complementa seu entendimento afiançando que: "De fato, divisão dos poderes, princípio da legalidade e direitos fundamentais correspondem a outras tantas limitações e, em última análise, as noções de soberania interna. Graças a esse princípio, a relação entre Estado e cidadãos já não é uma relação entre soberanos e súditos, mas sim entre sujeitos, ambos de

${ }^{27}$ SILVA, J. A. D. Curso de Direito Constitucional Positivo. 22. ed. São Paulo: Malheiros Editores, 2003. p. 158.

${ }^{28}$ BOBBIO, N. A Era dos Direitos. Nova. ed. Rio de Janeiro: Elsevier, 2004. p. 56.

29 FERRAJOLI, L. A soberania no mundo moderno: nasccimento e crise do Estado nacional. São Paulo : Martins Fontes, 2002. p. 28. 
soberania limitada [...] Sob esse aspecto, o modelo do estado de direito por força do qual todos os poderes ficam subordinados à lei, equivalente à negação da soberania". ${ }^{30}$

E, acrescenta: "Com a subordinação do próprio poder legislativo de maioria à lei constitucional e aos direitos fundamentais nela estabelecidos, o modelo do estado de direito aperfeiçoa-se e completa-se no modelo do estado constitucional de direito, e a soberania interna como potestas absoluta (poder absoluto), já não existindo nenhum poder absoluto, mas sendo todos os poderes subordinados ao direito, se dissolve definitivamente". ${ }^{31}$

Destarte, para Ferrajoli, soluciona-se a questão da limitação da soberania interna dos Estados, que, frente ao Estado democrático de direito, não teve outra sorte, a não ser de dissolver.

Já a soberania externa tomou um rumo diametralmente oposto. No período que compreende as duas guerras mundiais, de 1914 a 1945, tal fenômeno teve o seu apogeu. Não obstante, com a criação da ONU (organização das Nações Unidas) em 1945 e via da Declaração Universal dos Direitos do Homem, em 1948, ocorre o seu declínio, acarretando a limitação da soberania externa, em outras palavras, a soberania deixa de ser livre e absoluta; passando a se subordinar a dois preceitos fundamentais: o imperativo da paz e a tutela dos direitos humanos. Com essa mudança fulcral o próprio conceito de soberania internacional absoluta ou ilimitada, seguindo os passos trilhados pela soberania interna, torna-se incongruente. ${ }^{32}$

Ante o exposto, pode-se arrazoar que com a queda do poder soberano tradicional, o indivíduo passa a ocupar o posto de sujeito de direito internacional, posição a qual, até então, era de domínio exclusivo do Estado, dando início, assim, a um processo de internacionalização dos direitos humanos.

A corroborar o exposto, a consolidação do Direito Internacional dos Direitos Humanos só se deu em meados do século XX, com a percepção dos males

\footnotetext{
30 lbidem, p. 28.

31 Ibidem, p. 33.

32 Ibidem, p. 39-40.
} 
advindos do segundo conflito bélico mundial, precisamente em 1945, com o seu termo. 33

Sobre este episódio da história, Flávia Piovesan ensina que: "A barbárie do totalitarismo significou a ruptura do paradigma dos direitos humanos, por meio da negação do valor da pessoa humana como valor fonte do direito. Diante dessa ruptura, emerge a necessidade de reconstruir os direitos humanos, como referencial e paradigma ético que aproxime o direito da moral. Nesse cenário, o maior direito passa a ser, adotando a terminologia de Hannah Arendt, o direito a ter direitos". 34

Nesse diapasão impende destacar que, a Declaração Universal dos Direitos Humanos, adotada e proclamada pela Resolução 217 da Assembleia Geral das Nações Unidas, de 10 de dezembro de 1948, é sopesada como o marco da criação do chamado "Direito Internacional dos Direitos Humanos".

Sobre o assunto em tela, Fábio Comparato sabiamente sublinha que:

Inegavelmente, a Declaração Universal de 1948 representa a culminância de um processo ético que, iniciado com a Declaração de Independência dos Estados Unidos e a Declaração dos Direitos do Homem e do Cidadão, da Revolução Francesa, levou ao reconhecimento da igualdade essencial de todo ser humano em sua dignidade de pessoa, isto é, como fonte de todos os valores, independentemente das diferenças de raça, cor, sexo, língua, religião, opinião, origem nacional ou social, riqueza, nascimento, ou qualquer outra condição, como se diz em seu artigo II.

Ainda sobre o tema, é relevante o pensamento de Norberto Bobbio, afiançando que:

Com a Declaração de 1948, tem início uma terceira e última fase, na qual a afirmação dos direitos é, ao mesmo tempo, universal e positiva: universal no sentido de que os destinatários dos princípios nela contidos não são

33 COMPARATO, F. K. A afirmação histórica dos direitos humanos. 6. ed. São Paulo: Saraiva, 2008. p. 55 et seq; BOBBIO, N. A Era dos Direitos. Nova. ed. Rio de Janeiro: Elsevier, 2004. p. 62 et seq.; PASTOR RIDRUEJO, J. A. El proceso de internacionalización de los derechos humanos. El fin del mito de la soberanía nacional (I). Plano Universal: La obra de las Naciones Unidas. In: Consolidación de derechos y garantías: los grandes retos de los derechos humanos en el siglo XXI: seminario conmemorativo del 50 aniversario de la Declaración universal de los derechos humanos. Madrid: 1999. p. 35-46.

${ }^{34}$ PIOVESAN, F. Direitos Humanos e o Direito Constitucional Internacional. São Paulo: Saraiva, 2010. p. 122. 
mais apenas os cidadãos deste ou daquele Estado, mas todos os homens; positiva no sentido de que põe em movimento um processo em cujo final os direitos do homem deverão ser não mais apenas proclamados ou apenas idealmente reconhecidos, porém efetivamente protegidos até mesmo contra o próprio Estado que os tenha violado. ${ }^{35}$

Assim, pode-se, finalmente, arrazoar que o nível de abstração das teorias iniciais do século XII, foi transcendido, desaguando em um senário onde são construídas garantias jurídicas do cumprimento dos direitos humanos, até mesmo contra o próprio Estado que os violar.

Nessa perspectiva, pode-se dizer que o significado da institucionalização dos direitos humanos na ordem interna dos Estados, assim como no âmbito internacional, ganha relevo, ocasionando com que esses direitos sejam acautelados e tutelados numa esfera erga omnes, sendo algumas normas neste domínio reconhecidas como jus cogens. ${ }^{36}$

Muito embora a proteção dos direitos humanos na esfera internacional tenha evoluído, ainda podem ser observadas, em boa medida, dificuldades em sua propagação, uma vez que os desafios não são poucos quando se encontram em pauta questões tão controversas aos Estados. Motivo esse que acarreta com que o sistema de proteção internacional dos direitos humanos esteja longe de condizer com o que se espera quando se afirma a primazia dos indivíduos na ordem internacional.

\subsection{A Soberania como Responsabilidade}

Desde o seu nascedouro no século XVII, com os Tratados de Vestefália, que deram termo à guerra dos 30 anos, o Direito internacional clássico tem por elemento

${ }^{35}$ BOBBIO, N. A Era dos Direitos. Nova. ed. Rio de Janeiro: Elsevier, 2004. p. 29-30.

36 INTERNATIONAL COURT OF JUSTICE. Barcelona Traction. ICJ Reports (1970); Cf. MACHADO, J. Direito internacional: do paradigma clássico ao pós-11 de Setembro. Coimbra: Coimbra Editora, 2006. p. 363-364. 
basilar o Estado, 37 componente fundamental da macro política europeia após o fim do feudalismo e a derrocada da Igreja católica e do Santo Império Romano.

Consagrou-se, assim, uma nova fase na história política europeia, alicerçada no reconhecimento da igualdade soberana e na independência mútua dos Estados, concernente às relações internacionais, e na extinção da dependência de todos relativamente à Santa Sé. Mormente, é imperioso enaltecer a rejeição dos Estados perante a subordinação de qualquer autoridade superior. ${ }^{38}$

O princípio da soberania foi o princípio no qual os monarcas encontraram a justificação do seu absolutismo, apoiados e alentados pelos maiores filósofos da época (Jean Bodin, Vettel, Maquievel, Hobbes, Hegel, Jellinek, etc.). Num tal contexto, a vida internacional europeia passou a ser regida pelo princípio do equilíbrio de forças, do equilíbrio político ou da balança de poderes. ${ }^{39}$

A soberania do Estado consiste no direito do Estado de estabelecer de forma independente seus assuntos internos sem intervenção de um Estado terceiro. Resultante da ideia de que todos os Estados são iguais perante a comunidade internacional. O princípio da soberania era um dos pilares sustentadores do modelo de Vestefália do século XVII. ${ }^{40}$

Ainda na teoria tradicional, a soberania definia-se como competência exclusiva do Estado de livremente decidir sua política interna sem qualquer

37 De acordo com a célebre teoria dos três elementos, na doutrina do direito internacional tradicional, - Estado é o representante de uma população, regido por um governo, num determinado território. Uma vez que esses três elementos, o povo, o território e o governo soberano, encontrem-se em consonância, um Estado, na acepção legal, existe. Vide MACHADO, J. Direito internacional: do paradigma clássico ao pós-11 de Setembro. Coimbra: Coimbra Editora, 2006. p. 182-215; NGUYÊN, Q. D.; DAILLIER, P.; PELLET, A. Direito internacional público. Lisboa: Fundação Calouste Gulbenkian, 2003. p. 432-477.

38 Vide NGUYÊN, Q. D.; DAILLIER, P.; PELLET, A. Direito internacional público. Lisboa: Fundação Calouste Gulbenkian, 2003. p. 54 ss, 433-434; CAMILLERI, J. A.; FALK, J. The end of sovereignty?: The politics of a shrinking and fragmenting world. Aldershot: Edward Elgar, 1992. p. 12-15.

39 Sobre este tema Cf. CUNHA, J. D. S.; PEREIRA, M. D. A. D. V. Manual de direito Internacional Público. Coimbra: Almedina, 2004. p. 138; MACHADO, J. Direito internacional: do paradigma clássico ao pós-11 de Setembro. Coimbra: Coimbra Editora, 2006. p. 213-215; ALMEIDA, F. F. D. Direito Internacional Público. Coimbra: Coimbra Editora, 2003. p. 217-221; GOMES, C. A. A evolução do conceito de soberania : tendências recentes. Scientia luridica, p. 185-212, Jul./Dez. 1998. NGUYÊN, Q. D.; DAILLIER, P.; PELLET, A. Direito internacional público. Lisboa: Fundação Calouste Gulbenkian, 2003. p. 383-394.

40 FOX, H. The law of state immunity. Oxford: Oxford University Press, 2002. p. 24. 
interferência externa e, igualdade entre todos os Estados na esfera internacional. ${ }^{41}$ Ademais, trata-se, como bem observa Jonátas Eduardo Mendes Machado, do terceiro elemento constitutivo do Estado, ou seja, concerne ao "governo soberano", "poder supremo", "poder constituinte", "autoridade última", "poder dos poderes", "competência das competências", no núcleo de uma comunidade política territorialmente delimitada. ${ }^{42}$

O conceito de soberania é, atualmente, profundamente questionado. E, mais do que nunca, os avanços do Direito Internacional questionam os limites do princípio da soberania do Estado em relação ao ser humano, atualmente elevado a âmbito global e reconhecido não unicamente como sujeito de Direito Internacional, mas como fim último deste. ${ }^{43}$

No conceito contemporâneo, a soberania, apesar de constituir a fonte das competências estaduais, deixa de ser absoluta. "A soberania de cada Estado é limitada por idêntico atributo de todos os outros que the são iguais juridicamente, sendo, por consequência as necessidades de coexistência entre os sujeitos primários de Direito Internacional, e não propriamente a vontade dos Estados, a determinar a "compreensão" daquela majestosa". ${ }^{44}$

A doutrina voluntarista já admitia a limitação supramencionada: "As limitações da liberdade de um Estado, quer derivem do direito internacional comum quer de

\footnotetext{
${ }^{41}$ Schulz elucida que: "A principle contributor to the idea was Thomas Hobbes; his Leviathan--the sovereign state to which all individuals owed their loyalty--became a central part of the concept of sovereignty. Hugo Grotius argued that the law of nations generated force from the mutual consent of state sovereigns, who divined the sole power to make laws for their subjects from God". HUMESSCHULZ, S. Note: Limiting Sovereign Immunity in the Age of Human Rights. Harvard Human Rights Journal, n. 21, p. 105, Winter 2008.

42 MACHADO, J. Direito internacional: do paradigma clássico ao pós-11 de Setembro. Coimbra: Coimbra Editora, 2006. p. 213-215.

${ }^{43}$ Nesse sentido, Kant já ensinava que: "Admitindo, porém, que haja alguma coisa cuja existência em si mesma tenha um valor absoluto e que, como fim em si mesmo, possa ser a base de leis determinadas, nessa coisa e só nela é que estará a base de um possível imperativo categórico, quer dizer, de uma lei prática. Ora, digo eu: - O homem, e, de uma maneira geral, todo ser racional, existe como fim em si mesmo, não só como meio para o uso arbitrário desta ou daquela vontade. Pelo contrário, em todas as suas ações, tanto nas que se dirigem a ele mesmo como nas que se dirigem a outros seres racionais, ele tem sempre de ser considerado simultaneamente como fim. KANT, I. Fundamentação da metafísica dos costumes: texto integral. Porto : Areal, 2005. p. 76.
}

${ }^{44}$ ALMEIDA, F. F. D. Direito Internacional Público. Coimbra: Coimbra Editora, 2003. p. 217. 
compromissos contraídos, não afetam de modo algum, enquanto tais, a sua independência." 45

Contudo, é imperioso enaltecer que, apesar do modelo de Vestefália ter sido superado, com a limitação da soberania do Estado pelo Direito Internacional, especificamente o direito internacional dos direitos humanos, o Estado continua a desempenhar um papel de extrema relevância no direito internacional. Nesse mesmo diapasão, não há de se falar na superação do Estado, haja vista que o Estado não deixa de existir, mas sim numa evolução, num aperfeiçoamento do conceito de soberania. ${ }^{46}$

Insta salientar que, o principal escopo e fundamento do direito internacional moderno é a limitação da soberania do Estado, o que não significa que o mesmo esteja subordinado a um outro, mas sim no surgimento de um dever do Estado de respeitar regras mínimas que irão garantir igual privilégio a todos os outros Estados. 47 Ademais, como salienta Machado, "afasta-se hoje o entendimento de que os Estados são pessoas morais e realça-se o fato de que os mesmos são apenas recursos institucionais ao serviço dos cidadãos". ${ }^{48}$

O conceito acima aludido revela o entendimento contemporâneo da noção de soberania como responsabilidade. ${ }^{49}$

O então Secretário-Geral da ONU, Boutros-Ghali mencionou, em seu relatório "Un programa para paz", o conceito de soberania com responsabilidade ao afirmar que: "La piedra angular de este labor es y debe seguir siendo el Estado. El respecto

45 Opinião dissidente de Anziotti no caso do Regime aduaneiro austro-alemão, T.P.J.I., série $A / B$, no 41, p. 57. Cf. NGUYÊN, Q. D.; DAILLIER, P.; PELLET, A. Direito internacional público. Lisboa: Fundação Calouste Gulbenkian, 2003. p. 385.

46 MACHADO, J. Direito internacional: do paradigma clássico ao pós-11 de Setembro. Coimbra: Coimbra Editora, 2006. p. 182-216.

47 NGUYÊN, Q. D.; DAILLIER, P.; PELLET, A. Direito internacional público. Lisboa: Fundação Calouste Gulbenkian, 2003. p. 85-86.

48 MACHADO, J. Direito internacional: do paradigma clássico ao pós-11 de Setembro. Coimbra: Coimbra Editora, 2006. p. 214.

49 Nesse sentido, Slaughter afirma que: "A state's ability to control its own territory without external interference is no longer sufficient to allow it to govern its people-to provide security, economic stability and a measure of prosperity, clean air and water, and even minimum health standards". SLAUGHTER, A.-M. Security, Solidarity, And Sovereignty: The Grand Themes Of Un Reform. The American Journal Of International Law, v. 99, p. 619-631, 2005. 
de su soberanía e integridad fundamentales es crítico en todo progreso internacional común. No obstante ha pasado ya el momento de la soberanía absoluta y exclusiva; su teoría nunca tuvo asidero en la realidad. Hoy deben comprender-lo así los gobernantes de los Estados y contrapesar las necesidades de la nueva gestión interna con las exigencias de un mundo cada vez más interdependiente". 500 mesmo, ainda, elucidou a ideia da inevitável relação entre ordem interna e ordem externa.

Soberania como responsabilidade traduz-se, primeiramente, no comportamento do Estado, na esfera internacional, como sujeito de direito. Em segundo lugar, a soberania deve ser interpretada como direito/dever de cada Estado de desempenhar suas funções de Estado com responsabilidade seguindo as diretrizes do direito internacional. Por último, a soberania está intimamente atrelada a responsabilidade de acautelar os direitos fundamentais dos cidadãos e de fomentar o seu bem estar econômico e social, além de cooperar com a comunidade internacional na solução de problemas comuns. Destarte, a soberania encontra-se umbilicalmente atrelada a proteção dos direitos humanos. Em síntese, a soberania do Estado "potencialmente ilimitada no plano interno, encontra-se, na realidade, subordinada ao direito internacional e aos valores transnacionais de respeito pela dignidade da pessoa humana e pelos seus direitos básicos". 51

Immanuel Kant já ensinava que, a soberania deriva dos direitos universais dos indivíduos ao afirmar que, no Estado de Direito Cosmopolita, os Estados reconhecem uma ordem jurídica a eles superior, direito que deve ser seguido, mesmo com a ausência de uma autoridade central. Tal entendimento vem ao encontro da teoria contemporânea do Direito Internacional dos Direitos Humanos que impõe a primazia dos Direitos Humanos, cuja proteção está acima da soberania do Estado. Ademais, para Kant os direitos do homem devem ser considerados como

\footnotetext{
50 BOUTROS, BOUTROS-GHALI. Un programa de paz: Diplomacia preventiva, establecimiento de la paz y mantenimiento de la paz. Memorial del secretario General sobre la labor de la organización. (ONU A/47/277 - S/2411, 17 junio 1992). p. 9.

51 MACHADO, J. Direito internacional: do paradigma clássico ao pós-11 de Setembro. Coimbra: Coimbra Editora, 2006. p. 214.
} 
algo sagrado, por maiores que sejam os sacrifícios que ele custa ao poder dominante. 52

Nessa esteira, a existência do estado está intimamente atrelada à proteção dos direitos e liberdades do seu povo. Deste modo, a soberania pode ser considerada como uma conexão entre o indivíduo e o plano internacional. Diferentemente da teoria tradicional - na qual ela configura o poder soberano sobre o povo- a soberania atualmente é sinônimo da responsabilidade do Estado de representar o seu povo com justiça. ${ }^{53}$

Sublinhe-se que, negligenciar a proteção dos direitos humanos universais e permitir que um Estado atue como uma entidade alheia ao seu povo, seria abandonar a ideia de que os Estados não existem para si, mas para servir, proteger e representar seu povo. Essa omissão pode levar a negação de que o indivíduo possui o direito à proteção dos seus direitos humanos fundamentais. ${ }^{54}$

A corroborar o exposto, soberania como responsabilidade nada mais é do que o dever do Estado de assegurar os direitos e liberdades fundamentais do indivíduo. A sua inobservância pode acarretar na perda da legitimidade do Estado como membro da comunidade internacional.

\section{RESPONSABILIDADE INTERNACIONAL DO ESTADO NO DOMÍNIO DO DIREITO INTERNACIONAL DOS DIREITOS HUMANOS}

52 "O direito dos homens deve considerar-se sagrado, por maiores que sejam os sacrifícios que ele custa ao poder dominante; aqui não se pode realizar uma divisão em duas partes e inventar a coisa intermédia (entre direito e utilidade) de um direito pragmaticamente condicionado, mas toda a política deve dobrar os seus joelhos diante do direito, podendo, no entanto, esperar alcançar, embora lentamente, um estádio em que ela brilhará com firmeza". KANT, I. A paz perpértua e outros opúsculos. Lisboa: Edições 70, 2009. p. 177.

${ }^{53}$ MORIKAWA, M. M. Deslocados internos: entre a soberania do Estado e a protecção internacional dos Direitos do Homem : uma crítica ao sistema internacional de protecção dos refugiados. Coimbra: Coimbra Editora, 2006. p. 282-283.

${ }^{54}$ Cf. TESÓN, F. R. A Philosophy of International Law. Boulder: Westview Press, 1998. 
A responsabilidade internacional do Estado consiste, para a maior parte da doutrina, em uma obrigação internacional de reparação frente a uma violação prévia de norma internacional. É o que expõe lan Brownlie ao afirmar que: "o Direito da responsabilidade diz respeito à incidência e as consequências de atos ilegais e, em particular, ao pagamento de uma indenização pelos danos sofridos." 55 A responsabilidade do Estado é característica precípua de um sistema jurídico alicerçado no princípio da igualdade soberana dos Estados e no princípio da reciprocidade de direitos e deveres entre os Estados. ${ }^{56} \mathrm{De}$ fato, todos os Estados exigem o cumprimento dos acordos $e$ tratados que os beneficiam e, consequentemente, não podem desobrigar-se a cumpri-los, uma vez que todos eles são iguais. Sendo assim, a responsabilidade uma decorrência das relações simétricas de reconhecimento recíprocas. ${ }^{57}$

Por sua vez, a jurisprudência consagrou a responsabilidade internacional do Estado como princípio geral do Direito Internacional. Tal consagração pode ser vislumbrada em algumas decisões judiciais, nomeadamente a do caso do $\mathrm{S}$. $\mathrm{S}$. Wimbledom, na qual, a então existente, Corte Permanente de Justiça Internacional determinou que o descumprimento de uma obrigação internacional acarretaria em uma obrigação de reparar os danos causados; o que caracterizava, para a Corte, em um princípio de Direito Internacional. ${ }^{58}$ Esse princípio foi estabelecido pela Corte Permanente de Justiça no caso envolvendo a fábrica de Chorzów, ao deliberar que "[...] It is a principle of international law that the breach of an engagement involves an obligation to make reparation in an adequate form. Reparation therefore is the indispensable complement of a failure to apply a convention and there is no necessity for this to be stated in the convention itself. ${ }^{59}$ Acrescenta, ainda, em seu julgamento que: "[...] that it is a principle of international law, and even a general

55 BROWNLIE, I. Princípios de direito internacional público. Lisboa: Fundação Calouste Gulbenkian, 1997. p.458.

56 MACHADO, J. Direito internacional: do paradigma clássico ao pós-11 de Setembro. Coimbra: Coimbra Editora, 2006. p. 565-566.

57 RAMOS, A. D. C. Responsabilidade Internacional do Estado por Violação de Direitos Humanos. Revista CEJ, Brasília, n. 29, p. 53-63, abr./jun 2005.

58 PERMANENT COURT OF INTERNATIONAL JUSTICE. Case S.S. Wimbledom, P.C.I.J Series A, no 1, Julgamento de 17 August 1923.

59 PERMANENT COURT OF INTERNATIONAL JUSTICE. Case concerning the factory at Chorzów (Jurisdiction), Sentença de 26 de jul. de 1927, P.C.I.J. Series A. p. 21. 
conception of law, that any breach of an engagement involves an obligation to make reparation." 60

De acordo com o exposto, é verossímil a existência de um consenso quanto à existência do princípio da responsabilidade do Estado por atos ilícitos internacionais.

Com a análise das definições dadas pela doutrina e pela jurisprudência, a responsabilidade internacional do Estado pode ser entendida como, em essência, uma relação jurídica apreciada como instituto jurídico, princípio de direito, obrigação jurídica ou ainda como uma situação jurídica, pela qual o Direito Internacional confronta as violações perpetradas contra suas normas, ordenando imperiosamente a reparação dos danos causados, com o intuito primordial de preservar a ordem jurídica vigente. ${ }^{61}$

As questões concernentes à responsabilidade internacional do Estado começaram a ser consideradas desde 1956 pela Comissão de Direito Internacional da ONU (CDI), que a partir de então passou a basear os seus trabalhos em matéria de responsabilidade estadual nessa premissa fundamental. Inicialmente estava em causa a responsabilidade internacional dos Estados frente os cidadãos e sociedades comerciais estrangeiras no quadro das nacionalizações e da afirmação da soberania dos Estados sobre os recursos naturais. ${ }^{62}$ Com o avanço da matéria a aplicação da lógica da responsabilização internacional dos Estados frente à violação de normas internacionais alcançou toda a extensão do direito internacional.

Contudo, a CDI desenvolveu seus trabalhos relativos à responsabilidade internacional a partir de uma visão centrada nas relações entre Estados, ${ }^{63}$ deixando de lado a situação em que os Estados incorrem em responsabilidade por

60 PERMANENT COURT OF INTERNATIONAL JUSTICE. case concerning the factory at Chorzów Merits, julgamento de 13 de Set. de 1928, P.C.I.J. Series A, n. 17, p. 29.

61 RAMOS, A. D. C. Responsabilidade Internacional do Estado por Violação de Direitos Humanos. Revista CEJ, Brasília, n. 29, p. 53-63, abr./jun 2005. p. 53-63.

62 ROSENTOCK, R. The ILC and State Responsability. American Journal of International Law, v. 96, n. 4, p. 792-856, 2002. p. 792-856; CRAWFORD, J. The international law commission's articles on state responsibility: introduction, text and commentaries. Cambridge: Cambridge University Press, 2002. p. 1 e ss.

63 Cf. MCCORQUODALE, R. Impact on State Responsability. In: KAMMINGA, M. T.; SCHEININ, M. The impact of human rights law on general international law. Oxford; New York: Oxford University Press, 2009. p. 235-254. 
desrespeitar normas internacionais em detrimento de indivíduos e grupos. E é precisamente sobre isso que a seção do Direito Internacional Público denominado Proteção Internacional dos Direitos Humanos versa.

A proteção internacional aos Direitos Humanos teve seu nascedouro nas cartas de represália, - que representam os primórdios da proteção diplomática sistema pelo qual o indivíduo que sofresse algum dano em território estrangeiro possuía a prerrogativas de apelar para o Estado de sua nacionalidade com 0 objetivo que este exigisse a reparação do Estado responsável pelo dano. 64

Apesar de ter como seu antecedente histórico a proteção diplomática, a responsabilidade internacional do Estado por violações dos Direitos Humanos não pode ser considerada como fundamento da mesma, principalmente pelo fato da proteção diplomática considerar a lesão aos direitos de um indivíduo como uma lesão indireta ao Estado, ou seja, a proteção diplomática embasa-se na teoria de que o dano ao indivíduo estrangeiro configura dano indireto ao Estado de sua nacionalidade. Deste modo, o Estado ao conceder proteção diplomática a seu nacional, estaria exercendo direito próprio à reparação por dano indireto perpetrado por outro Estado. De fato, em 1924, a Corte Permanente de Justiça Internacional estabeleceu a primeira referência jurisprudencial nessa área, com o paradigmático caso Mavrommatis Palestine Concessions, Grécia vs. Reino Unido, no qual concluiu que o Estado ao conceder a proteção diplomática a seu nacional, está, na realidade, reafirmando seu direito de ver respeitadas as normas de Direito Internacional. 65

A responsabilidade internacional do Estado por violações dos Direitos Humanos encontra-se balizada no Direito Internacional dos Direitos Humanos, no qual o dano causado a um indivíduo passa a ser essencialmente do mesmo, sem a necessidade de mediação estatal, ante a natureza objetiva da obrigação de proteção

\footnotetext{
${ }^{64}$ No medievo, os suseranos que residiam no continente europeu emitiam cartas de represália a seus súditos no exterior, quando eram lesados em seus países de domicilio. Cf. TRINDADE, A. A. C. 0 direito internacional em um mundo em transformação: ensaios, 1976-2001. Rio de Janeiro; São Paulo: Renovar, 2002. p. 499-527

65 PERMANENT COURT OF INTERNATIONAL JUSTICE. Judgment of 30 August 1924. Case Mavrommatis Palestine concessions. PCIJ Series A, n. 2.
} 
aos Direitos Humanos. Ademais, esse ramo do Direito confere a todo indivíduo um rol de direitos internacionalmente consagrados. 66

A corroborar o exposto, originalmente, o regime da responsabilidade internacional do Estado tratava unicamente das disputas entre Estados. Todavia, a evolução das relações internacionais irrompeu uma nova vertente de disputas no Direito Internacional, na qual os danos deixavam de ser diretamente do Estado, passando a ser, também, dos seus nacionais. Desse modo, apesar da responsabilidade internacional do Estado por violação de direitos humanos ter sua raiz na responsabilidade internacional do Estado por danos causados a estrangeiros, o seu prisma sofreu alterações fulcrais, antes, direcionado ao Estado, agora, no indivíduo.

O regime acima elucidado foi expandido com 0 intuito de proteger os indivíduos de um Estado contra os arbítrios de um Estado estrangeiro. Como bem acentua Ferreira:

Com a criação e a ratificação dos tratados internacionais de direitos humanos a partir do fim da Segunda Guerra Mundial, os Estados provocaram uma transformação radical no regime da responsabilidade internacional. A partir de então, a responsabilidade internacional deixou de proteger apenas os interesses e reparar os danos e prejuízos causados por disputas internacionais. Estado X Estado ou por um Estado contra o nacional de outro. Agora, pela primeira vez, incorre em responsabilidade internacional o Estado que viola um dispositivo internacional que protege 0 direito de seus próprios nacionais. ${ }^{67}$

Nesse diapasão, sublinhe-se que, no que tange a proteção dos direitos humanos não há mais que se discutir, no estágio hodierno da sociedade internacional, sobre sua força vinculante, mas sim mecanismos que os proteja com efetividade. Nesse sentido, Bobbio ensina que: "não se trata de saber quais e quantos são esses direitos, qual é sua natureza e seu fundamento, se são direitos naturais ou históricos, absolutos ou relativos, mas sim qual é o modo mais seguro

66 Este entendimento pode ser vislumbrado no caso Ahmadou Sadio Diallo. INTERNATIONAL COURT OF JUSTICE. Ahmadou Sadio Diallo (Republic of Guinea v. Democratic Republic of the Congo), Merits, Judgment, I.C.J. Reports 2010. p. 639.

${ }^{67}$ FERREIRA, P. G. Responsabilidade Internacional do Estado. In: LIMA JR., J. B. Direitos Humanos Internacionais: avanços e desafios no início do século XXI. Recife: Movimento Nacional de Direitos Humanos, Regional Nordeste (MNDH - NE), 2001. p. 24 
para garanti-los, para impedir que, apesar das solenes declarações, eles sejam continuamente violados." 68

Nessa esteira, é imperioso enaltecer que, o Estado está incumbido de respeitar e garantir os direitos elencados nas normas internacionais, dentre eles os Direitos Humanos. ${ }^{69}$ Tal obrigação pode ser observado na Declaração Programa de Ação da Conferência Mundial de Direitos Humanos de Viena de 1993, 70 que afirma o dever dos Estados de implementar os direitos previstos nos tratados e convenções internacionais. Ademais, o programa assinala diversas recomendações para ampliar o grau de aplicação das normas internacionais de proteção dos Direitos Humanos. Desse modo, faz-se necessário observar, como a aplicação dos preceitos gerais que regem a responsabilidade internacional do Estado, a sua adequação ao contexto do direito internacional dos direitos humanos, evitando assim que se desenvolvam práticas internacionais estanques sobre a matéria. ${ }^{71}$

A adequação acima elucidada verifica-se, ainda, mais premente nos casos de violações dos valores fundamentas que afetam não unicamente um grupo de indivíduos, mas a comunidade internacional como um todo. Esse tipo de violação desafia a consciência jurídica universal, motor da evolução de todo Direito, sintomaticamente ameaçando a integridade dos pilares sustentadores do direito internacional. 72

Desta feita, a partir da ótica dos direitos humanos, a responsabilidade internacional do Estado deve abarcar, de maneira certeira, conjunturas em que

\footnotetext{
${ }^{68}$ BOBBIO, N. A Era dos Direitos. Nova. ed. Rio de Janeiro: Elsevier, 2004. p. 25.

${ }^{69}$ MCCORQUODALE, R. Impact on State Responsability. In: KAMMINGA, M. T.; SCHEININ, M. The impact of human rights law on general international law. Oxford ; New York: Oxford University Press, 2009. p. 246-247.

70 O § 13 reza que: "Existe a necessidade dos Estados e organizações internacionais, em cooperação com as organizações não-governamentais, criarem condições favoráveis, aos níveis nacional, regional e internacional, para garantir o gozo pleno e efetivo dos Direitos Humanos. Os Estados deverão eliminar todas as violações dos Direitos Humanos e respectivas causas, bem como os obstáculos ao gozo desses direitos".
}

71 RAMOS, A. D. C. Responsabilidade internacional por violações de Direitos Humanos: seus elementos, a reparação devida e sanções possíveis: teoria e prática do direito internacional. Rio de Janeiro: Renovar, 2004.p. 15.

72 TRINDADE, A. A. C. Os rumos do direito internacional contemporâneo: de um jus inter gentes a um novo jus gentium no século XXI. In: TRINDADE, A. A. C. 0 direito internacional em um mundo em transformação: ensaios, 1976-2001. São Paulo: Renovar, 2002. p. 1088. 
violações de certos preceitos de direito internacional, perpetradas por determinado Estado, atentem contra a comunidade internacional e não somente situações em que tem-se um Estado vis-à-vis outro Estado. Não obstante, a responsabilidade internacional do Estado por tais violações, consideradas graves, não deve perder seu caráter objetivo, cuja natureza está no dever de reparar os danos causados aos indivíduos lesionados. ${ }^{73}$

\subsection{A questão da Imputabilidade dos Estados}

A atribuição ou imputação de uma conduta a um Estado é um dos problemas com que a doutrina da responsabilidade internacional se depara. A principal questão que abrolha nessa matéria é quais são os atos ilícitos ou omissões, que somente podem ser praticados por um indivíduo, que poderão ser atribuídos a um Estado (pessoa abstrata), uma vez que o Estado só será responsabilizado por tais atos se os mesmos forem a ele atribuídos. ${ }^{74}$

A imputação é largamente admitida desde que 0 ato denunciado emane de pessoa ou de órgão sob a efetiva autoridade do Estado. ${ }^{75}$

Nas palavras de Shaw a imputabilidade seria "the legal fiction which assimilates the actions or omissions of state officials to the state itself and which renders the state liable for damages resulting to the property or person of an alien," 76 ou seja, é o elemento que vincula a conduta do agente ao Estado responsável. Desse modo, o Estado enquanto ente público comete atos ilícitos através de seus agentes. Avaliaremos a seguir quais desses atos podem vincular o Estado.

\footnotetext{
73 RAMOS, A. D. C. Responsabilidade internacional por violações de Direitos Humanos: seus elementos, a reparação devida e sanções possíveis: teoria e prática do direito internacional. Rio de Janeiro: Renovar, 2004. p. 410.

${ }^{74}$ O'BRIEN, J. International law. London [etc.]: Cavendish Publishing, 2002. p. 367 ss.

75 NGUYÊN, Q. D.; DAILLIER, P.; PELLET, A. Direito internacional público. Lisboa: Fundação Calouste Gulbenkian, 2003. p. 788.

${ }^{76}$ SHAW, M. N. International law. 5th. ed. Cambridge: Cambridge University Press, 2003. p. 701.
} 
Nos termos do projeto da CDI, a imputabilidade de um ato ilícito a um Estado verifica-se quando tal ato é perpetrado por um dos órgãos do Estado, dos poderes constituinte, legislativo, administrativo e jurisdicional, das forças armadas 77 , a qualquer nível de autoridade, de acordo o disposto no direito constitucional do Estado, ou por qualquer entidade a quem tenham sido legalmente atribuídas garantias de direito público, na hipótese de estarem no exercício das mesmas. ${ }^{78} \mathrm{~A}$ imputação de uma conduta a um Estado também pode ocorrer quando tal conduta é praticada por órgão de outro Estado, mas que esteja colocado ao serviço do primeiro. 79

A imputação de um ato ilícito verifica-se, mesmo, quando determinado órgão do Estado atua excedendo os limites de sua competência fixados pelo Estado, em outras palavras, a conduta será imputada ao Estado mesmo se o agente tenha agido ultra vires. ${ }^{80}$ De acordo com o Relatório da 53ํㅗㄹ Sessão da CDI, o Estado não pode refugiar-se por trás da noção de que, de acordo com as disposições de seu direito interno ou com as instruções que podem ter sido dadas a seus órgãos ou agentes, suas ações ou omissões não deveriam ter ocorrido ou tenha tomado uma forma diferente. Isso se dá ainda que o órgão ou entidade em questão tenha manifestamente cometido atos ilícitos ao abrigo de seu status oficial ou excedido suas competências. 81 Dessa maneira, no caso Caire ${ }^{82}$, o México foi responsabilizado pelos atos ilícitos praticados por suas forças armadas, pelo fato dos mesmos estarem no exercício de suas funções. Assim sendo, o presidente da Comissão de Reclamações Franco-Mexicanas, explicou:

\footnotetext{
${ }_{77}$ Nas palavras de O'Brien "in the law of state responsibility, armed forces will be regarded as part of the executive, although in most states subject to the direction of civilian politicians." O'BRIEN, J. International law. London [etc.]: Cavendish Publishing, 2002. p. 367.

78 Essa abordagem reflete o Direito consuetudinário. SHAW, M. N. International law. 5th. ed. Cambridge: Cambridge University Press, 2003. p. 70-702; p. 239

79 UNITED NATIONS. Draft Articles on Responsibility of States for Internationally Wrongful Acts. Resolution 56/83 of 12 December 2001, and corrected by document A/56/49. Artigos 4 ao 6으.

80 Ibidem, art. 7ㅇ․

81 INTERNATIONAL LAW COMMISSION. Draft Articles on Responsibility of States for Internationally Wrongful Acts. Suplement №. 10 (A/56/10), chp.IV.E.1November 2001. p. 45.
}

82 UNITED NATIONS. Estate of Jean-Baptiste Caire (France) v. United Mexican States. Reports of International Arbitral Awards, volume 7, June 1929. p. 516-534. 
[...] O Estado assume também a responsabilidade internacional por todos os atos cometidos pelos seus funcionários ou órgãos que constituam um delito de acordo com o Direito Internacional, independentemente de saber se o funcionário ou órgão atuou dentro dos limites da sua competência ou o excedeu [...]. Contudo, a fim de justificar a admissão desta responsabilidade objetiva do Estado por atos cometidos pelos seus funcionários ou órgão fora da sua competência, é necessário que estes tenham agido, pelo menos aparentemente, como funcionário ou órgão autorizado, ou que, ao agirem, tenham recorrido a poderes ou medidas apropriadas ao seu caráter oficial $[\ldots]$.

Ao Estado podem ser igualmente imputados os atos praticados por indivíduos ou grupos por ele trainados, equipados, armados, financiados ou apoiados para a realização de atividades militares e paramilitares contra outro Estado. ${ }^{83} \mathrm{O}$ mesmo preceito se se aplica as ações realizadas no exercício de poderes públicos em substituição ou na ausência do Estado. ${ }^{84}$

Já no caso das condutas de um movimento insurreto que deem origem a um novo governo de um Estado ou a um novo governo, ao Estado em causa serão imputados os atos ilícitos praticados pelas autoridades constituídas, pelos seus agentes, assim como aqueles perpetrados pelos insurretos. ${ }^{85}$

Existe, ainda, a possibilidade de um Estado ser imputado por ato a ele não atribuível quando o mesmo reconhece e adota a conduta em causa como sua. ${ }^{86}$ Também pode ser verificado, em alguns casos, a corresponsabilização de outro Estado, que ciente das circunstâncias, preste assistência ou auxílio, ou que adote

83 UNITED NATIONS. Draft Articles on Responsibility of States for Internationally Wrongful Acts. Resolution 56/83 of 12 December 2001, and corrected by document A/56/49. Artigo 8o; Cf. MACHADO, J. Direito internacional: do paradigma clássico ao pós-11 de Setembro. Coimbra: Coimbra Editora, 2006. p. 574-575; MIRANDA, J. Curso de direito internacional público. $4^{\mathrm{a}}$ ed. rev. e actualiz. ed. Parede: Princípia, 2009. p. 330-331.

84 UNITED NATIONS, op.cit., art. 9o; Cf. SHAW, M. N. International law. 5th. ed. Cambridge: Cambridge University Press, 2003. p. 705-706.

85 UNITED NATIONS, op.cit., art. 10; Cf. O'BRIEN, J. International law. London [etc.]: Cavendish Publishing, 2002. p. 370-371.

86 UNITED NATIONS, op.cit., art. 11; Cf. INTERNATIONAL LAW COMMISSION. Draft Articles on Responsibility of States for Internationally Wrongful Acts. Suplement №. 10 (A/56/10), chp.IV.E.1November 2001. p. 52-54; SHAW, M. N. International law. 5th. ed. Cambridge: Cambridge University Press, 2003. p. 707; MACHADO, J. Direito internacional: do paradigma clássico ao pós11 de Setembro. Coimbra: Coimbra Editora, 2006. p. 575. 
uma posição de direção e controle, na prática de uma conduta ilícita, como tal qualificável, se o mesmo tivesse sido perpetrado apenas por ele. ${ }^{87}$

Sublinhe-se que, mesmo quando um Estado coagir outro a perpetrar ato ilícito internacional, tanto o Estado coagido quanto o que coagiu, responderão pelo ilícito cometido, já que não fica prejudicada a responsabilidade do Estado que efetivamente cometeu $\mathrm{o}$ ato. ${ }^{88}$

Comumente, o nexo de imputação é dado pela culpa do agente, abarcando situações de dolo direto, dolo necessário e dolo eventual, assim como a negligência. Quando a determinação dos elementos subjetivos relevantes não for diáfana, a imputação poderá depender da existência de uma conduta internacionalmente imputável a um determinado órgão do Estado ou de uma falha no serviço. "No Direito Internacional, torna-se particularmente difícil fazer a prova dos elementos subjetivos e funcionais da negligência, pelo que o acento tônico reside na imputação a um Estado de uma conduta internacional ou perigosa, violadora de uma obrigação internacional". ${ }^{89}$ Uma violação de obrigação internacional também pode ser objetivamente imputável a um Estado, nesse caso não há a necessidade de se verificar qualquer culpa subjetiva ou falha de serviço. Essa é a chamada responsabilidade objetiva, que apesar de não constituir o objeto central e imediato da CDI, emerge com frequência no Direito Internacional especial.

Como já observado, a responsabilidade internacional é determinada pela secundarização dos elementos subjetivos atinentes à culpa do agente.

Foi observada pela doutrina uma recente evolução nesse campo, evidenciada por jurisprudências do Tribunal Europeu dos Direitos do Homem e do Tribunal Interamericano dos Direitos do Homem, no sentido de ampliar a imputação dos atos privados aos Estados, desde que tais condutas sejam perpetradas com a

87 UNITED NATIONS. Draft Articles on Responsibility of States for Internationally Wrongful Acts. Resolution 56/83 of 12 December 2001, and corrected by document A/56/49. Art. 16 e 17; MACHADO, J. Direito internacional: do paradigma clássico ao pós-11 de Setembro. Coimbra: Coimbra Editora, 2006. p. 576.

88 UNITED NATIONS, op.cit., art. 18; Cf. INTERNATIONAL LAW COMMISSION. Draft Articles on Responsibility of States for Internationally Wrongful Acts. Suplement №. 10 (A/56/10), chp.IV.E.1November 2001. p. 69-70.

89 MACHADO, J. op.cit., p. 576. 
cumplicidade regulatória do Estado. ${ }^{90}$ Assim, atualmente, pode ser vislumbrado um novo aspecto das funções tradicionalmente desempenhadas pelos Estados.

\subsection{Responsabilidade por Violações de Obrigações Internacionais}

A violação de uma obrigação internacional consiste num fato internacionalmente ilícito, podendo constituir em uma ação ou omissão; sendo suficiente o fato de que o comportamento não esteja em consonância com uma regra internacional de caráter consuetudinário ou convencional. ${ }^{91}$

Para um melhor entendimento sobre a violação de uma obrigação internacional, acima definida, é imperioso tecermos algumas considerações sobre a obrigação internacional em si, haja vista que, a inobservância da segunda resulta na primeira.

De acordo com a diferenciação das obrigações internacionais elaborada por Fitzmaurice, James Crawford em seu Terceiro Relatório sobre a responsabilidade internacional para o Tribunal Internacional de Justiça, delineou a distinção entre as obrigações internacionais bilaterais e as obrigações internacionais multilaterais. Segundo Crawford as obrigações bilaterais podem resultar de uma variedade de fontes, incluindo o direito internacional geral, tratados bilaterais ou multilaterais ou atos unilaterais. ${ }^{92}$ Tais obrigações podem ser divididas em: obrigações inter partes e erga omnes partes, sendo que a primeira resulta de um tratado bilateral ou multilateral restrito e a segunda diz respeito à proteção de um interesse coletivo

\footnotetext{
${ }^{90}$ CHARLESWORTH, H.; CHINKIN, C. The boundaries of international law: a feminist analysis. Manchester: Manchester University Press, 2000. p.148-151.

91 NGUYÊN, Q. D.; DAILLIER, P.; PELLET, A. Direito internacional público. Lisboa: Fundação Calouste Gulbenkian, 2003. p. 782; UNITED NATIONS. Draft Articles on Responsibility of States for Internationally Wrongful Acts. Resolution 56/83 of 12 December 2001, and corrected by document A/56/49. Artigos $2^{\circ}$ e $3^{\circ}$.

92 UNITED NATIONS. Document A/CN.4/507. Third report on State responsibility. International Law Commission Fifty-second session. 15 March 2000. § 100.
} 
definido por Estados partes num tratado multilateral aberto. ${ }^{93}$ Já as obrigações multilaterais tratam-se das obrigações integrais erga omnes, que são aquelas devidas à comunidade internacional na sua totalidade.

As obrigações erga omnes, como acima exposto, são um tipo de obrigação multilateral devida a comunidade internacional como um todo, sintomaticamente, todos os Estados possuem o interesse legal em seu cumprimento. ${ }^{94}$

A importância central em categorizar certas obrigações como de natureza erga omnes é tornar possível o entendimento de que em certos casos a responsabilidade internacional pode revestir-se de caráter multilateral. Esta categoria de obrigações foi consagrada no direito internacional pelo Tribunal Internacional de Justiça, no conhecido caso Barcelona Traction, ao afirmar que "[...] the responsibility engaged by the breach of these obligations is engaged not only in regard to the state which was the direct victim of the breach: it is also engaged in regard to all the other members of the international community [...]". ${ }^{95}$

Ademais, nesse mesmo caso, a Corte elaborou a distinção entre as obrigações erga omnes e as outras obrigações do Direito Internacional:

[...] "In particular, an essential distinction should be drawn between the obligations of a State towards the international community as a whole, and those arising vis-à-vis another State in the field of diplomatic protection. By their very nature the former are the concern of all States. In view of the importance of the rights involved, all States can be held to have a legal interest in their protection; they are obligations erga omnes." 96

Da sentença do Caso Barcelona Traction podem ser extraídas duas características das obrigações erga omnes. A primeira é a universalidade, uma vez

93 MACHADO, J. Direito internacional: do paradigma clássico ao pós-11 de Setembro. Coimbra: Coimbra Editora, 2006. p. 577; UNITED NATIONS. Document A/CN.4/507. Third report on State responsibility. International Law Commission Fifty-second session. 15 March 2000. §§ 103 e 104.

94 Cf. JORGENSEN, N. H. B. The responsibility of states for international crimes. Oxford: Oxford University Press, 2000. p. 93-96.

95 UNITED NATIONS. A/CN.4/SER.4/1976/Add. 1 (Part 2). Yearbook of the International Law Commission. Vol. II, Part Two, 1976. Report of the Commission to the General Assembly on the work of its twenty-eighth session. p. 99.

96 INTERNATIONAL COURT OF JUSTICE. Barcelona Traction, Light and Power Company, Limited (Belgium v. Spain) (New Application: 1962). Idem, § 33. 
que tais obrigações vinculam todos os Estados sem exceção. A segunda é a solidariedade, no sentido de que todos os Estados - e não unicamente o Estado lesado com a prática do ilícito - estariam habilitados a reagir, nomeadamente exigindo a reparação dos danos causados ou lançando mão de contramedidas. ${ }^{97}$

Um exemplo claro de obrigação erga omnes são as obrigações decorrentes dos direitos humanos, isso porque, essas obrigações não constituem unicamente uma promessa a um ou mais Estados individualmente, mas sim uma promessa perante a comunidade internacional, abrangendo muitos outros sujeitos e atores para além deles. O objetivo da obrigatoriedade dos direitos humanos é essencialmente o de prevenir o Estado de violar os direitos dos seus próprios nacionais. Para salvaguardar este objetivo os Estados curvam-se não a um outro Estado em particular, mas a todos os Estados. Do mesmo modo que a violação de um Direito Internacional no qual um Estado viola os direitos dos seus próprios cidadãos, não afeta, em princípio, um Estado mais que o outro. Tal violação lesa a coletividade de todos os Estados no seu conjunto. ${ }^{98}$

Por derradeiro, insta salientar que, atualmente, assiste-se uma clara superação do relativismo tradicional no plano normativo. A superação da regra segundo a qual as obrigações internacionais só vinculam os Estados mediante o seu consentimento deu passo a um mecanismo de proteção das obrigações erga omnes ao dispor de todos os Estados semelhantes a uma espécie de actio popularis umbilicalmente atrelada à ideia, acima elucidada, de universalização da responsabilidade internacional do Estado. ${ }^{99}$

\footnotetext{
97 RAGAZZI, M. The concept of international obligations Erga Ommes. Oxford: Clarendon Press, 1997. p. 12 ss; ALMEIDA, F. F. D. Direito Internacional Público. Coimbra: Coimbra Editora, 2003. p. 229-231.

98 PAUWELYN, J. Conflict of norms in public international law: how WTO law relates to other rules of international law. Cambridge : Cambridge University Press, 2003. p. 65.

99 NGUYÊN, Q. D.; DAILLIER, P.; PELLET, A. Direito internacional público. Lisboa: Fundação Calouste Gulbenkian, 2003. p. 206-207; GONZALEZ CAMPOS, J. D.; RODRIGUEZ, L. I. S.; MARIA, P. A. S. D. S. Curso de derecho internacional publico. Madrid: Editorial Civitas, 1998. De acordo com Almeida "No âmbito da proteção pela via jurisdicional, tal ato popularis parece, todavia não passar, por ora, de um exagero otimista, esbarrando no princípio da consensualidade subjacente ao funcionamento da justiça internacional; o que o próprio TIJ não deixou de reconhecer no caso de Timor-Leste, que, em 1995, opôs Portugal à Austrália." ALMEIDA, F. F. D. Direito Internacional Público. Coimbra: Coimbra Editora, 2003. p. 230.
} 
Chegou o momento de analisar qual a função do jus cogens na esfera da responsabilidade do Estado. Se as violações de obrigações erga omnes implicam um regime especial de responsabilidade, é de se esperar que um regime ainda mais particular seja reservado às violações do jus cogens, devido a sua importância máxima para a ordem jurídica internacional.

Nessa esteira é mister tecermos acerca da distinção entre o jus cogense e as obrigações erga omnes. Primeiramente, sublinhe-se que 0 direito cogente compreende normas que se diferenciam das demais pela sua imperatividade. Já as obrigações erga omnes são obrigações determinadas por normas que podem ter a natureza cogente ou não. Por conseguinte, pode-se dizer que, em regra, as normas de jus cogens dão origem às obrigações erga omnes, haja vista, destinam-se à comunidade internacional como um todo. 100 A recíproca, entretanto, não é verdadeira, uma vez que nem todas as obrigações erga omnes derivam de normas imperativas. Representadas pela doutrina como dois círculos concêntricos, as obrigações erga omens constituem um círculo maior que contém o círculo das normas imperativas, sem se limitar a estas. ${ }^{101}$

O direito cogente não é mencionado nominalmente pela Comissão em seu Projeto, entretanto a expressão empregada - "imperativa de direito internacional geral", análoga à da Convenção de Viena sobre o Direito dos Tratados - é uma menção incontestável a tais normas.

O jus cogens é tratado pela CDI no Capítulo III da $2^{\text {a }}$ Parte do Projeto, composto por apenas dois artigos reproduzidos a seguir:

Article 40. Application of this chapter

1. This chapter applies to the international responsibility which is entailed by a serious breach by a State of an obligation arising under a peremptory norm of general international law.

\footnotetext{
100 GONZALEZ CAMPOS, J. D.; RODRIGUEZ, L. I. S.; MARIA, P. A. S. D. S. Curso de derecho internacional publico. Madrid: Editorial Civitas, 1998. p. 344 ss.

101 Para mais informações acerca essa matéria vide BAPTISTA, E. C. lus cogens em direito internacional. Lisboa: LEX, 1995. p. 267 ss; TOUFAYAN, M. A Return to Communitarianism? Reacting to "Serious Breaches of Obligations Arising under Peremptory Norms of General International Law under the Law of State Responsibility and United Nations Law. The Canadian Yearbook of International Law, p. 209, 2004; JORGENSEN, N. H. B. The responsibility of states for international crimes. Oxford: Oxford University Press, 2000. p. 97.
} 
2. A breach of such an obligation is serious if it involves a gross or systematic failure by the responsible State to fulfill the obligation.

Article 41. Particular consequences of a serious breach of an obligation under this chapter

1. States shall cooperate to bring to an end through lawful means any serious breach within the meaning of

article 40.

2. No State shall recognize as lawful a situation created by a serious breach within the meaning of article 40, nor render aid or assistance in maintaining that situation.

3. This article is without prejudice to the other consequences referred to in this Part and to such further consequences that a breach to which this chapter applies may entail under international law.

Assim, segundo o artigo 40 do projeto, consideram-se como graves as violações das normas peremptórias ou imperativas de Direito Internacional (jus cogens), sistematicamente ou de forma grosseira. É o que ocorre, nomeadamente, em casos de agressão, de genocídio, tortura, destruição massiva de propriedade, etc. ${ }^{102}$ Contudo, sublinhe-se que, um único caso de tortura, por exemplo, não é suficiente para enquadrar o Estado neste capítulo, é mister, para tanto, que a tortura seja organizada e deliberada. ${ }^{103}$

Ressalte-se que, ao verificar-se esse tipo de violações do Direito Internacional, os Estados violadores enfrentam consequências diferenciadas, sendo elas de duas ordens. Primeiramente, em consonância com o primeiro parágrafo do artigo 41, os Estados devem cooperar entre si para fazerem cessar a violação, através de meios legais. ${ }^{104}$ Como pode ser vislumbrado, o preceito é vago e não fornece grandes detalhes de como tal cooperação entre Estados deve se dar.

O principal objetivo do parágrafo acima mencionado parece ser o de promover uma resposta multilateral e combater o unilateralismo, mormente pelo fato dos interesses em questão serem coletivos. Apesar de na prática a execução dessa disposição apresentar dificuldades, a mesma é um passo importante em favor da cooperação entre Estados.

102 MACHADO, J. Direito internacional: do paradigma clássico ao pós-11 de Setembro. Coimbra: Coimbra Editora, 2006. p. 580; Vide, por exemplo, o Processo instaurado junto ao TIJ em 28 de maio de 2002 pela República Democrática do Congo contra Ruanda.

103 CRAWFORD, J. The international law commission's articles on state responsibility: introduction, text and commentaries. Cambridge: Cambridge University Press, 2002. p. 247.

104 MACHADO, J. op. Cit., p. 580. 
Ainda, a obrigação exige que todos os Estados se interessem pelo ato ilícito, diferentemente do princípio clássico de não ingerência. $O$ que demonstra o aperfeiçoamento do anseio da existência de uma comunidade de Estados.

Além da obrigação de cooperar, o art. 41 prevê dois deveres negativos: a de não reconhecimento da situação ilegal, e a de não ajuda ou apoiar a sua manutenção, ou seja, é vetado aos Estados reconhecerem qualquer efeito jurídico a uma situação criada por violações de Direito Internacional e de prestarem qualquer auxílio ou assistência na manutenção dessa situação. ${ }^{105}$

Entretanto, para além dessas obrigações específicas, o fato de se estar diante de uma violação de direito cogente tem implicações no regime jurídico internacional.

\subsection{Direito à Reparação dos Indivíduos Vítimas de Violações Graves aos Direitos Humanos e de Direito Internacional Humanitário}

\subsubsection{O Dever do Estado de Prover Reparação aos Indivíduos Vítimas}

Já em 1927-1928, o Tribunal Permanente de Justiça Internacional deu reconhecimento judicial expresso a um preceito do direito internacional consuetudinário, o que reflete um princípio fundamental do direito internacional, no sentido que:

It is a principle of international law that the breach of an engagement involves an obligation to make reparation in an adequate form. Reparation

\footnotetext{
105 Vide por exemplo a Resolução 662 (1990) do Conselho de Segurança sobre a invasão do Kwait pelo Iraque, o Parecer Consultivo da CIJ no caso Consequências Legais para os Estados da Presença Continuada da África do Sul na Namíbia, 1970 e as Resoluções do Conselho de Segurança 418 (1977) e 569 (1985) proibindo ajuda ou assistência ao regime do apartheid na África do Sul. Cf. MACHADO, J. Direito internacional: do paradigma clássico ao pós-11 de Setembro. Coimbra: Coimbra Editora, 2006. p. 580; CRAWFORD, J. The international law commission's articles on state responsibility: introduction, text and commentaries. Cambridge: Cambridge University Press, 2002. p. 249.
} 
therefore is the indispensable complement of a failure to apply a convention and there is no necessity for this to be stated in the convention itself. 106

O Tribunal Permanente de Justiça Internacional acrescentou que:

The essential principle contained in the actual notion of an illegal act - a principle which seems to be established by international practice and in particular by the decisions of arbitral tribunals - is that reparation must, as far as possible, wipe out all the consequences of the illegal act and re-establish the situation which would, in. all probability, have existed if that act had not been committed. ${ }^{107}$

Os indivíduos que tiveram os seus direitos humanos violados são titulares (detentores de direitos) do correspondente direito à reparação. As vítimas são os verdadeiros portadores de direitos, incluindo o direito à reparação, como geralmente reconhecido atualmente. $\mathrm{O}$ mesmo cenário também pode ser vislumbrado hoje em dia, no domínio do Direito Internacional Humanitário. ${ }^{108} \mathrm{Um}$ estudo do Comitê Internacional da Cruz Vermelha (CICV) sobre as regras direito internacional humanitário consuetudinário pode ser trazido à baila neste contexto. $O$ artigo 150 reza que: "A State responsible for violations of international humanitarian law is required to make full reparation for the loss or injury caused." 109

Quanto à questão, específica, da reparação requerida diretamente por indivíduos, artigo 150 refere-se a uma tendência crescente a favor de conceder permissão a indivíduos vítimas de violações do direito humanitário internacional buscarem reparação diretamente do Estado responsável. 110

Nesse mesmo sentido, o artigo 33 (2) do Projeto de artigos sobre a Responsabilidade Internacional dos Estados prevê que o: "conteúdo da obrigação

106 PERMANENT COURT OF INTERNATIONAL JUSTICE. Case concerning the factory at Chorzów (Jurisdiction), sentença de 26 de jul. de 1927, P.C.I.J. Series A. p. 21.

107 PERMANENT COURT OF INTERNATIONAL JUSTICE. case concerning the factory at Chorzów Merits, julgamento de 13 de Set. de 1928, P.C.I.J. Series A. p. 47.

108 INTERNATIONAL COURT OF JUSTICE. Jurisdictional Immunities of the State (Germany v. Italy: Greece intervening). Dissenting opinion of Judge Cançado Trindade. Judgment of 3 February 2012. p. 69-70.

109 INTERNATIONAL COMMITTEE OF THE RED CROSS. Customary International Humanitarian Law- Volume I: Rules. Editado por Jean-Marie Henckaerts e Louise Doswald-Beck. Cambridge: Cambridge University Press, 2005. p. 537.

110 INTERNATIONAL COMMITTEE OF THE RED CROSS. Customary International Humanitarian Law- Volume I: Rules. Editado por Jean-Marie Henckaerts e Louise Doswald-Beck. Cambridge: Cambridge University Press, 2005. p. 541. 
internacional [...] não prejudica qualquer direito que a responsabilidade internacional de um Estado possa gerar diretamente em benefício de qualquer pessoa ou entidade distinta de um Estado." 111

Ademais, o Relatório da Comissão Internacional de Inquérito sobre a Situação em Darfur ao Secretário-Geral das Nações Unidas depois de afirmar que as graves violações dos direitos humanos e de direito internacional humanitário pode implicar não só a responsabilidade penal individual do agressor, mas também a responsabilidade internacional do Estado (ou entidade Estatal) em cujo nome o autor estava agindo, acrescentou que essa responsabilidade internacional implica que o Estado (ou a entidade Estatal) deve pagar uma indemnização à vítima. ${ }^{112}$

Após destacar o impacto do Direito Internacional dos Direitos Humanos no domínio da responsabilidade do Estado, o Relatório supra citado afirmou que atualmente há uma forte tendência no sentido de proporcionar compensação não só a Estados, mas também a indivíduos com base na responsabilidade do Estado. ${ }^{113}$ Por fim, o Relatório conclui que:

[...] based on [...] the body of law on human rights, the proposition is warranted that at present, whenever a gross breach of human rights is committed which also amounts to an international crime, customary international law not only provides for the criminal liability of the individuals who have committed that breach, but also imposes an obligation on States of which the perpetrators are nationals, or for which they acted as de jure or de facto organs, to make reparation (including compensation) for the damage made. ${ }^{114}$

Além disso, o Projeto de Declaração dos Princípios Internacionais de Direito de Reparação às Vítimas de Conflitos Armados, de 2010, do Comitê Internacional sobre Reparação para Vítimas de Conflitos defende, em seu artigo 6, a posição eminente dos indivíduos no Direito Internacional dos Direitos Humanos, e não vê

111 UNITED NATIONS. Draft Articles on Responsibility of States for Internationally Wrongful Acts. Resolution 56/83 of 12 December 2001, and corrected by document A/56/49. art. 33 (2).

112 UNITED NATIONS. Report of the International Commission of Inquiry on Darfur to the United Nations Secretary-General. Geneva, 25 January 2005. para. 593.

113 Ibidem, p. 151 n. 217.

114 Ibidem. para. 598. 
razão pela qual os indivíduos deveriam ter uma posição mais fraca de acordo com as regras do direito internacional aplicável nos conflitos armados. ${ }^{115}$

Nesse mesmo diapasao, os Princípios e Directrizes Básicas sobre o Direito a Recurso e Reparação para Vítimas de Violações Flagrantes das Normas Internacionais de Direitos Humanos e de Violações Graves do Direito Internacional Humanitário, em seu artigo 15, reza que:

Em conformidade com a sua legislação interna e as suas obrigações jurídicas internacionais, um Estado deverá assegurar a reparação das vítimas por actos ou omissões que possam ser imputáveis ao Estado e constituam violações flagrantes de normas internacionais de direitos humanos ou violações graves do direito internacional humanitário. ${ }^{116}$

Todos estes desenvolvimentos recentes vão além da dimensão interestatal estrita e tradicional, ao estabelecerem o direito dos indivíduos à reparação como vítimas de graves violações dos direitos humanos e do direito internacional humanitário. ${ }^{117}$

Ad argumentandum, uma vez que um Estado cometer violações aos direitos humanos (pertencente ao rol de normas cogentes), no qual o indivíduo é o titular do direito a reparação referente a tais infrações, o Estado não pode renunciar os direitos que não Ihes pertencem. Não se pode, de forma alguma, menosprezar uma evolução tão significativa nas áreas de direito internacional, tais como as do Direito Internacional dos Direitos Humanos e Direito Internacional Humanitário, de modo a privar a pessoa humana do seu direito à reparação. Isto conduziria a uma notória injustiça.

\footnotetext{
115 INTERNATIONAL LAW ASSOCIATION. The Hague Conference (2010). Draft Declaration of International Law Principles on Reparation for Victims of Armed Conflict (Substantive Issues).

116 UNITED NATIONS. Basic Principles and Guidelines on the Right to a Remedy and Reparation for Victims of Gross Violations of International Human Rights Law and Serious Violations of International Humanitarian Law. Resolution adopted by the General Assembly, 21 March 2006, A/RES/60/147.

117 Cf. INTERNATIONAL COURT OF JUSTICE. Jurisdictional Immunities of the State (Germany v. Italy: Greece intervening). Dissenting opinion of Judge Cançado Trindade. Judgment of 3 February 2012. p. 71 et seq.
} 


\section{IMUNIDADE DE JURISDIÇÃO DO ESTADO}

Primeiramente, é imperioso determinar o instituto da imunidade de jurisdição do Estado estrangeiro para, ulteriormente, estabelecer a sua relação com as demandas atinentes às violações aos direitos humanos, como se fará a seguir.

\subsection{Conceituando Imunidade de Jurisdição}

A imunidade de jurisdição corresponde a um conjunto de preceitos negativos que estabelecem quando uma corte não tem o condão de julgar um caso. ${ }^{118}$

A compreensão do instituto da imunidade do Estado parte inicialmente do entendimento de alguns aspectos elementares da jurisdição do Estado. Inicialmente, é mister desmembrarmos a expressão "imunidade de jurisdição". O termo jurisdição deriva do latim jurisdictio ${ }^{119}$ e possui duas definições: uma mais ampla, associada à autoridade de um poder soberano para governar, legislar, interpretar e aplicar a direito, e outra mais específica, ligada à ideia da capacidade do Estado determinar o direito no âmbito das ordens jurídicas internas e internacionais emitindo decisões judiciais.

Pode-se asseverar que a jurisdição, no seu sentido mais amplo, é o poder público competente, amplo e limitado do Estado, de exercer sua autoridade e administrar sua justiça, dentro de determinada circunscrição territorial ou até mesmo no âmbito internacional, concernentes à determinado assunto do seu interesse. ${ }^{120}$ Assim, pode-se dizer que essa acepção de jurisdição é uma das formas que o poder soberano estatal se manifesta, agindo através de seus órgãos internos, por intermédio da criação, alteração e extinção de normas; aplicando-as aos fatos sociais concretos; pelo desempenho legal da coerção e do poder de polícia que

\footnotetext{
118 Cf. BRÖHMER, J. State Immunity and the Violations of Human Rights. Amsterdã: Martinus Nijhoff, 1997. p. 37.

119 NUNES, P. Dicionário de tecnologia jurídica. 13ª ed. Rio de Janeiro: Renovar, 1999. p. 665.

120 Ibidem, p. 665.
} 
possui dentro do suas fronteiras, ou até mesmo fora dela, de acordo com os limites impostos pelo direito internacional, observado o direito dos demais Estados. ${ }^{121}$

Contudo é a definição de jurisdição específica que será utilizada no trabalho ora encetado. Quer isto dizer que, será empregada a acepção stricto sensu da jurisdição, segundo a qual dentre as três principais competências do Estado, a que tem precípua relevância na presente investigação é a judiciária ou jurisdicional.

Ponderando que a jurisdição ${ }^{122}$ de um Estado a princípio é ilimitada, consistindo, nas palavras de Humberto Theodoro Júnior, no "poder que toca ao Estado, entre as suas atividades soberanas, de formular e fazer atuar praticamente a regra jurídica concreta que, por força do direito vigente, disciplina determinada situação jurídica" ${ }^{123}$, que se aplica a tudo e a todos em seu território, e que a competência ${ }^{124}$ é a mensuração, a limitação e a distribuição deste poder, a

${ }^{121}$ BRIERLY, J. L. Direito internacional. 4a. ed. Lisboa: Fundação Calouste Gulbenkian, 1979. p.219 ss; REZEK, J. F. Direito internacional público: curso elementar. 7ª . ed. São Paulo: Saraiva, 1998. p. 226.

122 De acordo com Cândido Rangel Dinamarco, a jurisdição é a "função do Estado, destinada à solução imperativa de conflitos e exercida mediante a atuação da vontade do direito em casos concretos". DINAMARCO, C. R. Instituições de direito processual civil. 4. ed. São Paulo: Malheiros, v. 1, 2004. p. 309.

123 THEODORO JÚNIOR, H. Curso de Direito Processual Civil. 41. ed. Rio de Janeiro: Forense, v. 1, 2005. p. 32.

124 O Código de Processo Civil Brasileiro regula a matéria nos seguintes termos:

Art. 88 - É competente a autoridade judiciária brasileira quando:

I - o réu, qualquer que seja a sua nacionalidade, estiver domiciliado no Brasil;

II - no Brasil tiver de ser cumprida a obrigação;

III - a ação se originar de fato ocorrido ou de fato praticado no Brasil.

Parágrafo único - Para o fim do disposto no $\mathrm{n}$ 일, reputa-se domiciliada no Brasil a pessoa

jurídica estrangeira que aqui tiver agência, filial ou sucursal.

Art. 89 - Compete à autoridade judiciária brasileira, com exclusão de qualquer outra:

I - conhecer de ações relativas a imóveis situados no Brasil;

II - proceder a inventário e partilha de bens, situados no Brasil, ainda que o autor da

herança seja estrangeiro e tenha residido fora do território nacional.

Não obstante a clareza dos artigos em estabelecer a competência da justiça brasileira, é frequente a confusão entre os instituto de competência e jurisdição. Segundo Theodoro Júnior, quando o Código se refere à "competência internacional", não está tratando unicamente de competência, mas sim da jurisdição em si, em outas palavras, está definindo as possibilidades de atuação do própio poder jurisdicional do Estado. A conclusão do ilustre doutrinador, corroborada por Dinamarco, mostra de forma diáfana a ambiguidade e incerteza que permeiam os dois conceitos, precipuamente no que tange á competência internacional. Contudo, é mister considerar a jurisdição como um poder ilimitado, tornando-se, desse modo, possível distingui-la da competência internacional, que seria uma limitação, auto imposta pelo Estado, do poder de julgar quaisquer lides que estejam perante seus magistrados. Cf. THEODORO JÚNIOR, H. Curso de Direito Processual Civil. 41. ed. Rio de Janeiro: Forense, v. 1, 2005; DINAMARCO, C. R. Instituições de direito processual civil. 4. ed. São Paulo: Malheiros, v. 1, 2004; MADRUGA FILHO, A. A Renúncia À Imunidade de Jurisdição 
imunidade teria a capacidade de afastar a jurisdição, atuando como uma exceção a esta.

Assim, uma corte nacional, depois de definir se é detentora ou não da jurisdição para o caso, ira verificar se as normas atinentes à imunidade são aplicáveis a este denunciado específico e, se demonstrado que ele é imune a essa ação, a corte deverá privar-se de julgar o litígio que, se não fosse por essa conjuntura sui generis da qual emana a imunidade, sujeitar-se-ia normalmente à jurisdição da corte. ${ }^{125}$ É nessa mesma esteira de pensamento, Accioly e Silva consideram a imunidade como uma restrição a um dos atributos da soberania interna de um Estado, especificamente a jurisdição, direito fundamental que é anterior e inerente à condição do Estado, e que será demarcado pela imunidade. ${ }^{126}$

Destarte, a imunidade de jurisdição é a isenção, privilégio ou prerrogativa legal que um Estado possui, por não poder ser submetido às jurisdições dos tribunais de um outro Estado, ${ }^{127}$ salvo em algumas determinadas situações que serão analisadas mais adiante. Por outra perspectiva, a imunidade consiste numa exceção ou limite imposto aos Estados pelo direito internacional, ao regular o exercício das suas jurisdições nacionais, quando um dos seus pares forem partes em procedimentos judiciais. ${ }^{128} 129$

Pelo Estado Brasileiro e o Novo Direito da Imunidade de Jurisdição. Rio de Janeiro: Renovar, 2003; BRÖHMER, J. State Immunity and the Violations of Human Rights. Amsterdã: Martinus Nijhoff, 1997.

${ }^{125}$ BRÖHMER, J. State Immunity and the Violations of Human Rights. Amsterdã: Martinus Nijhoff, 1997. p. 37 ss.

126 ACCIOLY, H.; SILVA, G. E. D. N.; CASELLA, P. B. Manual de Direito Internacional Público. São Paulo: Saraiva, 2010. p. 116-117.

127 SINCLAIR, S. I. The Law of Sovereign Immunity: Recent Developments. Recueil des Cours de l'Académie de Droit International de La Haye, v. 167, p. 121-217, 1980.

128 Cf. NGUYÊN, Q. D.; DAILLIER, P.; PELLET, A. Direito internacional público. Lisboa: Fundação Calouste Gulbenkian, 2003. p.461463.

129 O princípio da imunidade é formulado pelo artigo 5ำ do convenção sobre imunidade do Estado e seus bens: "Um Estado goza de imunidade, respectivamente a si próprio e à sua propriedade, perante a jurisdição dos tribunais de outro Estado, ressalvadas as disposições da presente Convenção". Cf. UNITED NATIONS. Supplement No. 49 (A/59/49), United Nations Convention on Jurisdictional Immunities of States and Their Property. Adopted by the General Assembly of the United Nations on 2 December 2004. Official Records of the General Assembly, Fifty-ninth Session 
A imunidade de jurisdição pode ser bem ilustrado no caso de uma corte nacional ter plena jurisdição para decidir sobre um determinado litígio, ${ }^{130}$ mas é impedida de exercê-la neste caso particular, porque uma das partes processuais é um Estado soberano ou ainda um dos seus órgãos. Em princípio, a imunidade é baseada na identidade do litigante, ou seja, trata-se de uma questão ratio personae. Entretanto, uma vez que reste diáfana que a identidade de uma das partes origina a imunidade (a ratio materiae), o fato de a pessoa (i.e. o Estado) ser realmente detentora da imunidade poderá depender na substância do ocorrido (uma questão ratione materiae). ${ }^{131}$

Assim sendo, qual é o fundamento da imunidade? Por que deve ser concedida, em primeiro lugar? O que um Estado estrangeiro tem de tão importante, ao ponto de ser imune de um processo judicial de um outro Estado, especialmente quando isso pode causar uma severa adversidade a um nacional que é, de tal modo, privado de uma reparação legal normal? Inúmeras teorias foram apresentadas, como será elucidado a seguir.

(a) Perante o Direito Internacional todos os Estados são iguais, ou seja, inexiste qualquer hierarquia entre eles (princípio da igualdade). A máxima par in parem non habet judicium expressa a ideia de que nenhum Estado soberano pode ser submetido, contra sua vontade, à condição de parte perante foro doméstico de um outro Estado. ${ }^{132} 133$ Sintomaticamente, o Estado A deve ser imune a jurisdição

130 É mister delinearmos a distinção entre o princípio da imunidade de jurisdição do princípio da "não justiciabilidade". Quando uma demanda é não justiciável, quer isso dizer que a corte nacional não tem competência de exercer jurisdição, ou seja, a matéria da questão é de tal natureza que não pode ser objeto de um processo judicial perante uma corte nacional. Em outras palavras, a não justiciabilidade é embasada na matéria da disputa - é uma questão ratio materiae. Por outro lado, o princípio da imunidade de jurisdição é competente para julgar o caso, contudo, não é lhe permitido o exercício dessa prerrogativa em um caso especifico, pelo fato de uma das partes ser um Estado estrangeiro. A imunidade tem como base, em primeiro lugar, a identidade do litigante - é uma questão ratio personae. Cf. DIXON, M. Textbook on international law. 5a . ed. Oxford: Oxford University Press, 2005. p. $164-165$

131 Ibidem, p.165; SINCLAIR, S. I. The Law of Sovereign Immunity: Recent Developments. Recueil des Cours de l'Académie de Droit International de La Haye, v. 167, p. 199, 1980.

132 Cf. REZEK, J. F. Direito internacional público: curso elementar. 7a. ed. São Paulo: Saraiva, 1998. p. 173; BAPTISTA, E. C. Direito internacional público: Sujeitos e responsabilidade. Coimbra: Almedina, v. II, 2004; SINCLAIR, S. I. The Law of Sovereign Immunity: Recent Developments. Recueil des Cours de l'Académie de Droit International de La Haye, v. 167, p. 198-199, 1980.

133 Tal como asseverou o Tribunal Europeu de Direitos Humanos: "sovereign immunity is a concept of international law, developed out of the principle par in parem non habet imperium, by virtue of which 
do Estado B, haja vista que, o primeiro não possui autoridade sobre o último, sendo que os dois têm o mesmo status. A passagem geralmente mais citada sobre o tema é o acórdão do Supremo Tribunal dos Estados Unidos no caso Schooner Exchange v. Mcfaddon, ${ }^{134}$ o qual reza que:

Sendo esta jurisdição territorial total ou absoluta um atributo de todos os
soberanos e sendo incapaz de conferir um poder extraterritorial, não parece
contemplar como seus objetos nem os soberanos estrangeiros nem os seus
direitos soberanos. Não estando um soberano, em nenhum caso, sujeito a
autoridade de outro e estando vinculado, por obrigações do mais elevado
caráter, a não denegrir a dignidade da sua nação (colocando-se a si próprio
ou aos seus direitos soberanos no âmbito da jurisdição de um outro
Estado), presume-se que só entra num território estrangeiro ao abrigo de
uma autorização expressa ou confiando que as imunidades inerentes à sua
categoria de soberano independente, ainda que não estipuladas
expressamente, lhe estão reservados por natureza e lhe serão concedidas.

Esta igualdade perfeita e independência absoluta dos soberanos, este interesse comum que os complete a uma relação mútua e a um intercâmbio de bons ofícios, deram origem a um conjunto de casos em que se considera que cada soberano renunciou ao exercício de uma parte dessa jurisdição territorial completa e exclusiva, que se declarou ser atributo de cada nação.

A corroborar o exposto, o fundamento da imunidade de jurisdição tem como alicerce os princípios da soberania, igualdade e independência dos Estados, expressados pela máxima par in parem non habet judicium, como foi asseverado sobre o assunto no caso caso Schooner Exchange, "na igualdade perfeita e independência absoluta dos soberanos", se traduz na autolimitação do poder jurisdicional estatal vinculada ao princípio da reciprocidade com outros Estados. ${ }^{135}$

(b) A imunidade do Estado tem como base sustentadora a renúncia da jurisdição feita pelo Estado territorial soberano, através do qual abre mão do seu direito absoluto (jurisdição territorial). A motivação por traz dessa autorização é que

one State shall not be subject to the jurisdiction of another State" Cf. EUROPEAN COURT OF HUMAN RIGHTS. Case of Fogarty v. the United Kingdom (Application no. 37112/97). Judgment, 21 November 2001. parágrafo 34; EUROPEAN COURT OF HUMAN RIGHTS. Case of Al-adsani v. the United kingdom (Application no. 35763/97). Judgment, 21 November 2001. parágrafo 54.

134 U.S. SUPREME COURT. The Exchange v. McFaddon. In: Volume 11, 1812. Para mais detalhes vide BROWNLIE, I. Princípios de direito internacional público. Lisboa: Fundação Calouste Gulbenkian, 1997. p. 346-348; DIXON, M. Textbook on international law. 5a . ed. Oxford: Oxford University Press, 2005. p.166.

135 GONZALEZ CAMPOS, J. D.; RODRIGUEZ, L. I. S.; MARIA, P. A. S. D. S. Curso de derecho internacional publico. Madrid: Editorial Civitas, 1998. p. 426. 
sem ela, nenhum Estado estaria disposto a realizar transações comerciais com os nacionais de nenhum outro Estado. A imunidade, portanto, repousa sobre a renúncia voluntária da jurisdição pelo Estado territorial soberano, uma vez que esse é o único termo em que um Estado encontra-se apto para atuar no território de outro. ${ }^{136}$

(c) De acordo com Lord Denning MR no caso Rahimtoola v. Nizam of Hyderabad 137 e, reiterado pelo mesmo, no caso Thai-Europe Tapioca Service v. Government of Pakistan, ${ }^{138}$ uma corte nacional não deve considerar os méritos de uma disputa judicial - na qual um Estado soberano estrangeiro é uma das partes que envolva questões políticas. No seu ponto de vista, assas questões não devem ser objetos de decisão em uma corte nacional. Embora, essa possa ser um motivo prático para que os juízes locais hesitem em julgar casos em que um Estado estrangeiro esteja envolvido, essa não é uma explanação convincente da imunidade. Como Dixon ensina, imunidade é a perda de jurisdição devido à complexidade ou delicadeza da questão. ${ }^{139}$

(d) A regra geral aplicada à imunidade do Estado no direito do Reino Unido é a de que uma decisão proferida por uma corte nacional não pode ser imposta a um Estado estrangeiro. Isso se dá mesmo em casos nos quais o Estado estrangeiro demandado não for detentor da imunidade de jurisdição, contradizendo a execução da decisão judicial dada pela corte nacional. Por esse motivo, há uma chance real de que as decisões proferidas por cortes nacionais não sejam respeitadas por Estados estrangeiros, além de não haver muitos meios para que tais decisões sejam asseguradas. Nesses casos, tem-se defendido de que a melhor de solucionar a situação poderia ser a de conceder total imunidade perante o processo judicial no seu todo. Assim, consequentemente, a imunidade, nessa conjuntura, não passa de um reflexo das dificuldades práticas envolvidas na aplicação das decisões judiciais contra Estados estrangeiros. Quer isso dizer que, a imunidade seria concedida em todos os casos nos quais um Estado estrangeiro for parte em um processo,

${ }^{136}$ DIXON, M. Textbook on international law. 5a . ed. Oxford: Oxford University Press, 2005. p.166. 137 HOUSE OF LORD. Rahimtoola, appellant v. Nizam of Hyderabad and Another, respondents. Paquistão, 1957.

138 Thai-Europe Tapioca Service $v$ Government of Pakistan, The Harmattan (1975) 1 Weekly Law Report 1485, 1491F

139 DIXON, M. op. cit., p.166. 
simplesmente pelo fato desses casos abrolharem problemas de aplicação. Não obstante, resta diáfana que a imunidade de jurisdição não é concedida em todos as casos e, de fato, as circunstâncias nas quais é atribuída têm diminuído nos últimos anos, apesar dos problemas de aplicação. Assim, pode-se dizer que a imunidade não é simplesmente um fruto da necessidade. ${ }^{140}$

(e) Uma outra teoria sobre a imunidade é a de que ela teria como base a cortesia internacional. De acordo com essa teoria, a imunidade teria sido concedida com o intuito de fomentar cooperação internacional e evitar disputas desnecessárias entre o Estado foro e outros membros da comunidade internacional. Isso não significa que a condição relativa à imunidade estatal é em si baseada na cortesia internacional, ao invés da obrigação legal. Até porque, resta incontestável que, o Estado territorial soberano tem a obrigação legal internacional de conceder a imunidade. O que essa teoria sugere, no entanto, é que, a imunidade foi originalmente criada para fomentar boas relações, ao proteger os Estados estrangeiros das vicissitudes dos sistemas legais nacionais. De acordo com Dixom "if this was a motivating factor of the doctrine, it is ironic that the wheel has now turned full circle". Isso porque, um recente desenvolvimento, que tem restringido as circunstâncias em que a imunidade é concedida, foram projetadas para proteger o indivíduo quando este lidar com um Estado estrangeiro, e não o contrário. Contudo, é verossímil que a imunidade é um conceito flexível e que pode responder às exigências de uma sociedade internacional em movimento. ${ }^{141}$

Apesar de serem inúmeras as teorias sobre a imunidade, o ponto mais importante sobre o tema é que o princípio da imunidade é corroborada pela prática dos Estados. Qualquer que seja a sua base ou fundamento jurídico para a doutrina, é evidente que a imunidade do Estado está vivo e bem na prática do direito nacional e internacional.

Como será elucidado adiante, a imunidade de jurisdição do Estado estrangeiro sofreu profundas transformações nos últimos anos, sendo seu âmbito de aplicação paulatinamente restringido, não havendo conformidade, entretanto, a

\footnotetext{
140 Ibidem, 2005, p. 166.

141 Ibidem, 2005, p. 167.
} 
respeito da medida exata em que tal concessão deve ser realizada, o que acarreta acalorados debates na esfera acadêmica. A discussão acerca da extensão e natureza da imunidade torna-se ainda mais controvérsia quando os delitos perpetrados pelo Estado incluem violações aos direitos humanos, ${ }^{142}$ tema que será objeto de estudo no decorrer deste trabalho. Nessas conjunturas, a concessão de imunidade do Estado violador vem de encontro com a proteção e valorização conferida aos direitos humanos atualmente, e "como resultado, um Estado pode evitar em grande parte a responsabilidade por seus atos ou omissões quando a defesa da imunidade estiver disponível". ${ }^{143}$

Considerado o preceito da imunidade de jurisdição do Estado, cumpre analisar a sua evolução histórica, ou seja, a transição do paradigma absoluto para a teoria relativa.

\subsection{Desenvolvimento Histórico da imunidade de Jurisdição do Estado Estrangeiro}

A evolução histórica do direito da imunidade é uma história de vitória da teoria restritiva sobre a teoria absoluta. A consumação desse triunfo, na esfera do direito internacional, foi lento, paulatino e um processo gradual que perdurou por mais de um século. Esta trajetória também foi de aperfeiçoamento e particularização.

Pode-se dizer que a doutrina da imunidade atual desenvolveu-se, precipuamente, em consequência das decisões proferidas pelos tribunais nacionais em casos nos quais um Estado era uma das partes. Tribunais ao redor do mundo iniciaram o seu contributo para tal evolução lentamente, mas com o decorrer dos

\footnotetext{
142 Nas palavras de Antonio Boggiano, e.g. "Consideramos a jurisdição internacional como o poder de regular causas, casos, assuntos ou conflitos não exclusivamente internos de um ordenamento jurídico. Inclusive, um assunto exclusivamente interno pode eventualmente internacionalizar-se pela possível responsabilidade internacional, v.g., as obrigações assumidas em um tratado sobre direitos humanos". BOGGIANO, A. Derecho internacional: derecho de las relaciones entre los ordenamientos jurídicos y derechos humanos. Buenos Aires: La Ley, 2001. p.13.
}

143 BRÖHMER, J. State Immunity and the Violations of Human Rights. Amsterdã: Martinus Nijhoff, 1997. p. 4 
anos desenvolveram um ramo do direito plenamente desenvolvido, frequentemente com normas e princípios elaborados e detalhados, embora efetuado de forma heterogênea, sobre várias restrições a serem impostas à imunidade jurisdicional dos Estados estrangeiros; e em torno deste vasto conjunto de jurisprudência desenvolveu-se um discurso acadêmico cada vez mais sofisticados.

Nesse diapasão, imunidade de jurisdição do Estado estrangeiro sofreu notável transformação com o passar dos últimos séculos, alterações estas originadas, em sua maioria, pela própria modificação da função exercida pelo Estado no âmbito internacional. O papel característico assumido pelo Estado em cada período histórico estabeleceu, destarte, a sintomática alteração na aplicação do instituto ora perscrutado, em uma que originou o entendimento contemporâneo da imunidade soberana.

\subsubsection{O advento da Imunidade de Jurisdição: a transposição do rei para o Estado}

Para melhor analisar o instituto da imunidade de jurisdição, que inicialmente era entendido de forma absoluta, quer isso dizer que, até o século $\mathrm{XX}$ os Estados em geral gozavam de imunidade absoluta perante os tribunais de outro Estado, é mister tecermos uma contextualização histórica desse instituto para melhor visualizarmos sua evolução e transformação na doutrina internacional, que passou a adotar a tese da imunidade relativa ou limitada de jurisdição do Estado estrangeiro.

A primeira formulação da imunidade deu-se através do costume internacional, que consagrou a regra par in parem non habet judicium, "[...] nenhum Estado soberano pode ser submetido contra sua vontade à condição de parte perante o foro 
doméstico de outro Estado" 144 regra essa que teria sua reformulação nos séculos posteriores, nas formas das imunidades absolutas e das imunidades relativas. ${ }^{145}$

O advento de teorias de fenômenos subtraídos à jurisdição de uma autoridade local, imunidades, atribuem-se a alguns lugares em particular que, consagrados ao culto divino, não assentiriam a prática de atividades que não fossem exclusivamente conexas aos serviços religiosos. Na Grécia Clássica e em todos os períodos da Civilização romana, no interior de templos, cemitérios e locais onde se realizavam atividades religiosas, entendia-se que os poderes das autoridades locais cessavam, em respeito à superioridade dos seres e dos lugares que eram a eles dedicados. ${ }^{146}$

Com advento e o desenvolvimento do Cristianismo a sacralidade de determinados locais estendeu-se a outros, como os mosteiros e conventos, mas sempre subordinada à teoria de que tais lugares deveriam estar fora dos poderes das autoridades leigas, por serem consagrados ao culto de um único Deus, além das pessoas a seu serviço. Consequentemente, a sacralidade de sítios, logo se estenderia à sacralidade das funções neles exercidas e, do mesmo modo, às pessoas que as exercem, que não estariam dentro do poder das autoridades leigas. O preceito das imunidades passou, desse modo, a incorporar-se ao status do indivíduo, sem que houvesse qualquer diferenciação entre as qualidades da pessoa e os atos por ele perpetrados. ${ }^{147}$

Nesse mesmo diapasão, não é de estranhar que a doutrina atribui o advento da imunidade de jurisdição a uma passagem da imunidade historicamente concedida aos próprios soberanos - os reis e príncipes de outrora- ao Estado-nação - então personagem emergente do panorama mundial.

Nessa mesma esteira de pensamento, Antenor Pereira Madruga Filho entende que: "Não houve a criação de uma nova imunidade, apenas a transferência da titularidade da imunidade, que deixa de ser atributo pessoal do governante, tido

\footnotetext{
${ }^{144}$ REZEK, J. F. Direito internacional público: curso elementar. 9ª ed. São Paulo: Saraiva, 2002. 145 SOARES, G. F. D. S. Origens e justificativas da imunidade de jurisdição. In: MADRUGA, A. P. F.; GARCIA, M. Imunidade de jurisdição e o judiciário brasileiro. Brasília: CEDI, 2002. p. 25.

146 Ibidem, p. 25-26.

147 Ibidem, p. 26.
} 
como soberano, passando a ser atributo da pessoa jurídica do Estado. Nesse caso, a mutação estaria não no instituto da imunidade, mas na feição externa do soberano." 148 Do mesmo modo, Arroyo ensina que: "A imunidade de jurisdição foi estabelecida na época das monarquias absolutas, quando a pessoa do soberano se confundia e identificava com o Estado mesmo, critério que reinou pacificamente em todo o mundo e foi mantido em virtude do princípio de DIP par in parem non habet imperium, sustentando-se na igualdade e soberania própria dos Estados". ${ }^{149}$

A corroborar o exposto, pode ser observado que, o nascedouro do instituto ora estudado repousa na remota prática de concessão de certas prerrogativas aos soberanos que, sendo representantes dos desígnios de Deus na terra, não poderiam ser jurisdicionáveis. Portanto, pode-se concluir que, a origem da imunidade de jurisdição do estado estrangeiro não é autônoma, isso porque, o seu surgimento não passa da transposição da aplicação da máxima de Bártolo de Saxoferrato "par in parem non habet imperium" 150 para os novos agentes do cenário mundial: os Estados que, por serem detentores de personalidade jurídica própria, desatavam-se cada vez mais das pessoas de seus respectivos monarcas.

\subsubsection{A Teoria Absoluta da Imunidade}

A origem do termo "imunidade" (do Latim immunitas, derivado de immunis) deu-se em meados do século XIII; a palavra foi usada, a partir de então, para referirse à condição de alguém isento de impostos ou de quaisquer encargos ou taxas. No

\footnotetext{
148 MADRUGA FILHO, A. A Renúncia À Imunidade de Jurisdição Pelo Estado Brasileiro e o Novo Direito da Imunidade de Jurisdição. Rio de Janeiro: Renovar, 2003. p. 160.

149 ARROYO, D. F. Derecho internacional privado de los estados del Mercosur: Argentina, Brasil, Paraguay, Uruguay. Buenos Aires: Zavalia, 2003. p. 143.

150 Bartolo de Sassoferrato , em 1554, no seu "Tractatus repraesaliarum", introduziu a idéia de que se um sistema jurídico for igual a outro não poderia ser aplicado a estrangeiro, porque este teria o seu "imperium" atingido. Daí a fórmula "par in parem non habet imperium". O autor assevera que a imunidade dos Estados tem a sua origem nos monarcas do absolutismo, vez que eles se identificam com o Estado. Assim sendo, a imunidade do Estado era um prolongamento dado soberano. Cf. WOOLF, C. N. S. Bartolus of Sassoferrato: his position in the history of medieval political thought. Cambridge: Cambridge University press, 1913.
} 
final do século XIX, o termo "imunidade" foi introduzido no léxico de direito constitucional e direito internacional (em relação aos parlamentares e diplomatas, respectivamente). No direito penal, tornou-se associado a "causa da impunidade". ${ }^{151}$ No direito internacional, o termo passou a ser usado, também, em relação às "prerrogativas" do Estado soberano. ${ }^{152}$

Desse modo, o termo "imunidade" sempre foi destinado a elucidar algo absolutamente excepcional, a isenção de jurisdição ou de execução. Essa expressão nunca foi elaborada para ser um "princípio", nem uma norma de aplicação geral. O vocábulo "imunidade", certamente, nunca teve como escopo, a sua invocação como uma exceção de jurisdição para encobrir crimes internacionais, e muito menos atrocidades ou graves violações dos direitos humanos ou do direito humanitário internacional. Muito menos pretendia-se excluir reparações às vítimas de tais atrocidades e violações graves. ${ }^{153}$

A imunidade de jurisdição possuiu, por um longo período de tempo, caráter plenamente absoluto, pois era aplicada de forma praticamente irrestrita, isso porque era praticada de maneira análoga à imunidade concedida à pessoa do soberano. Quando a imunidade é acertada como absoluta, a mesma "acarreta a exclusão de qualquer intervenção de juiz ou autoridade administrativa de um Estado, em qualquer controvérsia que diga respeito à Estado estrangeiro, diretamente, bem como em relação às emanações deste". ${ }^{154}$

Na esfera da jurisprudência, o conceito absoluto da imunidade foi cristalizado por intermédio da paradigmática decisão, proferida pela Suprema Corte dos Estados Unidos da América em 1812, concernente ao caso da Escuna Exchange, ${ }^{155}$ na qual

${ }^{151}$ CORNU, G. Vocabulaire juridique. 7a . ed. Paris: PUF, 2005. p . 467.

152 Ibidem, p. 468.

153INTERNATIONAL COURT OF JUSTICE. Jurisdictional Immunities of the State (Germany v. Italy: Greece intervening). Dissenting opinion of Judge Cançado Trindade. Judgment of 3 February 2012. p. 49.

${ }^{154}$ ACCIOLY, H.; SILVA, G. E. D. N.; CASELLA, P. B. Manual de Direito Internacional Público. São Paulo: Saraiva, 2010. p. 338; YANG, X. State Immunity in International Law. Cambridge: Cambridge University Press, 2012. p. 7-10.

155 Este caso tratou-se da disputa sobre a propriedade de uma escuna que pertencia a John M'Faddon e Greetham Williamdois, dois americanos, que partiu de Baltimore, Maryland, em 27 de outubro de 1809, para São Sebastians, Espanha, tendo sido apreendido por ordem de Napoleão 
a sentença do Chief Justice Marshall corrobora a tese do caráter absoluto da imunidade, excepcionado, dessa forma, a França da imunidade de jurisdição das cortes norte-americanas. Assim, essa decisão é considerada como o procedente que norteou cortes não unicamente dos Estados Unidos, mas de inúmeros outros Estados, e atribuiu imunidade absoluta e irrestrita, salvo renúncia do Estado, ${ }^{156}$ restando os indivíduos lesados sem praticamente nenhum remédio. ${ }^{157}$

Nesse sentido, no caso Compania Naviera Vascongado v. Steamship "Cristina" [1938] AC 485, o principal caso relativo a imunidade absoluta, Lord Atkin seu início ao seu julgamento com a seguinte definição de imunidade estatal, p. 490:

The foundation for the application to set aside the writ and arrest of the ship is to be found in two propositions of international law engrafted into our domestic law which seem to me to be well established and to be beyond dispute. The first is that the courts of a country will not implead a foreign sovereign, that is, they will not by their process make him against his will a party to legal proceedings whether the proceedings involve process against his person or seek to recover from him specific property or damages.

The second is that they will not by their process, whether the sovereign is a party to the proceedings or not, seize or detain property which is his or of which he is in possession or control. There has been some difference in the practice of nations as to possible limitations of this second principle as to whether it extends to property only used for the commercial purposes of the sovereign or to personal private property. In this country it is in my opinion well settled that it applies to both.

Bonaparte, imperador francês. A escuna foi levada para a França e passaram a usá-lo como navio de guerra da marinha francesa, seno rebatizado com o nome de Balaou. M'Faddon e Greetham alegaram que tinham o direito de propriedade e à posse da Balaou, que atracou no porto americano devido ao mau tempo. Eles acreditavam que a Balaou foi ilegalmente confiscada pelo governo da França. Na época, a França estava envolvida com a Guerra de 1812. A decisão inicial estabeleceu que, sendo a embarcação um navio de guerra de uma potência estrangeira em paz comos Estados Unidos, o caso não se submeteria aos tribunais comuns do país. Esta decisão foi revertidaem sede de apelação, tendo o procurador distrital interposto recurso à Suprema Corte visando à reforma da sentença anterior por razões eminentemente políticas. Cf. U.S. SUPREME COURT. The Exchange v. McFaddon. In: Volume 11, 1812.

156 Segundo Xiaodong Yang: "[...] absolute immunity was never truly absolute: it could be waived by the defendant State, and courts regularly did assume jurisdiction in cases involving local immovable property pursuant to the ancient principle of lex rei sitae." YANG, X. State Immunity in International Law. Cambridge: Cambridge University Press, 2012. p. 8.

157 DIXON, M. Textbook on international law. 5a . ed. Oxford: Oxford University Press, 2005. p. 155166; TROOBOFF, P. Foreign State Immunity: Emerging Consensus on Principles. Recueil des Cours Collected Courses of The Hague Academy of International Law, v. 200, p. 252-274, 1986. 
Já a jurisprudência norte americana, no Caso Berizzi bros. Co. v. The Pesaro, 271 U.S. 562, 174 (1926) "The Pesaro", a Suprema Corte declarou inequivocamente que, p. 145:

The decision in The Exchange therefore cannot be taken as excluding merchant ships held and used by a government from the principles there announced. On the contrary, if such ships come within those principles, they must be held to have the same immunity as war ships.

Se ainda após essa decisão houvese qualquer dúvida a respeito da matéria, a mesma foi dirimida pelo julgamento do caso Compania Espanola v. The Navemar, 303 U.S. 68 (1938), no qual Suprema Corte declarou novamente que, p. 303:

Admittedly a vessel of a friendly government in its possession and service is a public vessel, even though engaged in the carriage of merchandise for hire, and as such is immune from suit.

O paradigma da imunidade absoluta perdurou por um longo período na doutrina e jurisprudência do direito internacional. ${ }^{158}$ Contudo, esse cenário sofreu alterações com as transformações ocorridas no panorama político, social e econômico do século XIX, como será observado a seguir.

\subsubsection{A Teoria Relativa da Imunidade}

A teoria da imunidade do Estado foi constituída em um tempo no qual quase não existia preocupação com o tratamento dispensado pelos Estados aos indivíduos sob suas respectivas jurisdições. Aos poucos, a introdução gradual ocorreria no decurso do século XIX.

158 Segundo Madruga: "Convém relembrar que, apesar de os tribunais belgas e italianos jamais terem aplicado a imunidade absoluta dos Estados estrangeiros e não obstante a resolução do Instituto de Direito Internacional, firmada em 1891, já propor uma imunidade apenas relativa, firmou-se inicialmente um costume internacional próximo à prática norte-americana, conferindo à prerrogativa de imunidade um caráter quase absoluto". MADRUGA FILHO, A. A Renúncia À Imunidade de Jurisdição Pelo Estado Brasileiro e o Novo Direito da Imunidade de Jurisdição. Rio de Janeiro: Renovar, 2003. p. 158. 
Nesse período os Estados assumiram também o papel de empresários comerciais em grande escala, originando grandes monopólios comerciais em áreas específicas, construindo e gerindo ferrovias, companhias de navegação e serviços postais e, consequentemente alterando o papel por ele desempenhado, passando a envolver-se de forma cada vez mais intensa em áreas antes dominados pela ação dos particulares, gerando um aumento de suas relações de caráter privado. ${ }^{159} \mathrm{~A}$ atividade comercial da época foi incrementada pela Primeira Guerra Mundial, acarretando no surgimento dos Estados socialistas e comunistas a uma maior proeminência do setor público nas economias nacionais. Ademais, Estados como a Índia acreditavam que era necessário ser detentor de um setor público como ponto de partida para o desenvolvimento planeado de uma economia moderna. Assim os Estados passam a praticar, além dos tradicionais atos de governo, executados no gozo de suas prerrogativas soberanas, atos de natureza comercial, com maior frequência, executadas com base em sua capacidade privada, na qualidade de pessoa jurídica sujeita a direito privado. 160

O cenário acima ilustrado provocou uma necessidade de se ponderar um tratamento jurídico diverso para os atos dos Estados, não mais limitados às suas atribuições estritamente políticas e administrativas atinentes ao governo do país. Destarte, eclode a diferenciação entre os atos de governo (acta jure imperii) e os atos de Direito privado (acta jure gestionis). ${ }^{161}$

A imunidade restritiva foi consagrada pela jurisprudência dos tribunais da Itália e da Bélgica, que inauguraram uma nova tendência no campo do Direito Internacional ao negarem a concessão da imunidade de jurisdição para os atos perpetrados pelos Estados estrangeiros em sua capacidade privada. ${ }^{162}$

159 BROWNLIE, I. Princípios de direito internacional público. Lisboa: Fundação Calouste Gulbenkian, 1997. p. 348-349

160 CASSESE, A. International law. 2ª. ed. Oxford: Oxford University Press, 2005. p. 98-101.

161 BROWNLIE, I. op. cit., p. 353-356.

162 Quanto a jurisprudencia belga vide COURT OF APEAL. Rau, van den Abeele et Cie v. Duruty, decision confirmed by the Court of Appeal. Ghent, 1879; COUR DE CASSATION. Chemins des fer Liegeois-Luxembourg v. Etat nérderlandais. Bélgica, 1903. Para verificar as decisões dos tribunais Italianos vide NAPLES COURT OF CASSATION. Typaldos v. Manicomio di Aversa, Cass. Napoli, 1886; FIRENZE COURT OF CASSATION. Gutierres ex parte Bey di Tunisi v. Emilik, Cass. 
O caso mais antigo registrado de imunidade restritiva foi o caso Rau v Duruty, decidido em 1879 pelo Tribunal de Recurso de Ghent da Bélgica, concernente à uma ação contra o transporte de guano enviados para Porto Ostend, na Bélgica. O tribunal assumiu a jurisdição sobre o caso pelo fato de que, quando o Estado vendeu guano e perpetrou contratos universalmente considerados como comerciais, de acordo com o Tribunal o caso deve ser submetido à jurisdição dos tribunais comerciais.

A doutrina da imunidade restritiva teve a sua aprovação final na Bélgica em 1903, pela Court of Cassation no case Chemins des Fer Liegeois-limbourgeois C. L'Etat néerlandais. ${ }^{163} \mathrm{~A}$ empresa querelante perpetrou uma ação requerendo o reembolso de pecúnia por ele pago antecipadamente ao governo Holandês, nos termos do contrato assinado pelas partes referente à ampliação de uma estação ferroviária na Holanda. O Tribunal decidiu que, quando um estado não estiver exercendo o poder público (puissance publique) e praticar atos de cunho privado (personne civile ou prive'e) em conformidade com o direito privado (droit privé), assim sendo, o Estado não poderia gozar de imunidade, e a competência do tribunal deriva da da natureza do ato (nature de l'acte) em questão. A distinção entre atos de cunho público e privado foi corroborada no caso Monnoyer, atinente à compra, efetuada por uma agência do governo francês, de matérias-primas e equipamentos da Bélgica. ${ }^{164}$

A prática dos Tribunais italianos teve uma transição no período de 1882 a 1886. Em 1882, com caso de Morellet, que envolveu a sucessão de bens da Dinamarca na Itália, a Corte de Cassação deliberou que o Estado existe não só como "entidade política" (ente político), mas também como "pessoa coletiva no sentido limitado do direito privado" (persona giuridica nel senso ristretto del diritto privato) e deve, se necessário, "exercer os direitos civis do mesmo modo que qualquer outra pessoa jurídica [Corpo morale] ou pessoa física. Assim, quando um

Firenze, 1886. Cf. SCISO, E. Italian Judges' Point of View on Foreign States' Immunity. Vanderbilt Journal of Transnational Law, v. 44, p. 1201-1231, 2011.

163 COUR DE CASSATION. Chemins des fer Liegeois-Luxembourg v. Etat nérderlandais. Bélgica, 1903.

${ }^{164}$ CHARLEROY CIVIL COURT. Sociéteé Monnoyer v. France. Belgium, 1927. 
Estado estrangeiro atuar na esfera do direito privado no território italiano, os tribunais italianos podem fazer valer a sua jurisdição. ${ }^{165}$

A jurisprudência suíça passou a plicar a teoria restritiva desde 1918, quando o Tribunal Federal (Bundesgericht), no caso Dreyfus confirmou a validade de uma ordem de penhora contra o patrimônio da Áustria no que diz respeito a uma reivindicação para o retorno de Notas do Tesouro Nacional Austríaco que circulavam na Suíça. O Tribunal Federal estabeleceu uma distinção entre atos decorrentes do exercício do poder soberano (jure imperii), no qual o Estados gozava de imunidade e os atos praticados pelo Estado como sujeito de direito privado (jure gestionis), no qual o Estado não poderia invocar imunidade. O distinção entre o jure imperii e jure gestionis e a exigência de vínculo territorial, desde então constituem os dois pilares da jurisprudência suíça sobre a imunidade do Estado. ${ }^{166}$

Os tribunais gregos têm praticado a doutrina da imunidade restritiva desde 1928, quando a imunidade foi negada em um caso envolvendo a venda e entrega de bovinos por parte da União Soviética para um cidadão grego. ${ }^{167}$

A França foi, dentre os Estados acima citados, foi o primeiro a aderir a teoria da imunidade restritiva. De fato, a primeira manifestação nesse sentido, pode ser datada no ano de 1849. Somente no início do século $X X$ é que algumas medidas ambivalentes podem ser observadas na jurisprudência francesa. Por vez, declarações antagônicas pode ser encontradas nos casos franceses, até mesmo após a diferenciação entre atos de império e atos de gestão terem sido aceitos pela jurisprudência francesa. O primeiro caso que decidiu claramente com base na imunidade restritiva porque o "ato em questão não possuía caráter de atos do poder público", foi o caso Roumania v. Pascalet de 1924, concernente à aquisição por parte de um Estado estrangeiro de bens de uma empresa francesa. A partir de

\footnotetext{
165 CORTE DI CASSAZIONE. Morellet v. Governo Danese, Italy, 1882. American Journal of International Law. v. 26, Suplement (1932). p. 481-482 e 595-596.

166 SWISS FEDERAL COURT. Dreyfus. Switzerland, 1918. Cf. YANG, X. State Immunity in International Law. Cambridge: Cambridge University Press, 2012. p.14.

167 SUPREME COURT. Soviet Republic Case. Greece, 1928.
} 
então, a imunidade passou a ser negada nos casos em que um Estado pratique atividade comercial. ${ }^{168}$

Os Estados Unidos passaram a adotar a teoria da imunidade restritiva em 1952, com a doção da notória Tate Letter, instrução do Departamento de Estado dos EUA às cortes do país, delineou-se a nova política do país sobre o tema, adotando a teoria restritiva da imunidade soberana em relação aos pedidos dos governos estrangeiros de concessão de imunidade de jurisdição.

É imperioso elucidarmos que, a Tate Letter, a princípio, foi apena uma típica declaração unilateral de caráter diplomático, quer isso dizer que, a Tate Letter não foi concebida com o intuito de fornecer orientação para os tribunais nacionais. No entanto, posteriormente foi, de facto, o Departamento de Estado dos EUA, que passou determinar, acerca dos pedidos de Estados estrangeiros, sobre a concessão ou indeferimento da imunidade. Essa tem sido uma longa prática dos EUA; os tribunais regularmente antes de deliberarem se irã conceder ou não a imunidade, pedem a "opinião" Departamento de Estado sobre o caso; e apenas possuem autonomia para decidirem quando o Departamento do Estado de recusar a agir ou for omisso sobre a matéria. Essa subordinação ao Poder Executivo tem sido considerado um "princípio norteador" pela Suprema Corte dos EUA, em cuja opinião: "It is ... not for the courts to deny an immunity which our government has seen fit to allow, or to allow an immunity on new grounds which the government has not seen fit to recognize". 169

Conforme exposto no Chuidian v. Philippine National Bank:

In practice, however, the determination of whether a suit was barred under the principles of the Restatement was made not by the courts but by the State Department. Typically, a foreign state or instrumentality faced with a suit in a court in our country would apply to the State Department for a finding of immunity. The State Department would make a determination, considering the common law principles expressed in the Restatement, and would convey the finding to the relevant court by filing a "suggestion." In fact,

\footnotetext{
168 COURT OF APPEAL OF POITIERS. Roumania (Sate of Roumania) v. Aricastre, France. Poitiers, 1949; Cf. YANG, X. State Immunity in International Law. Cambridge: Cambridge University Press, 2012. p. 15.

169 UNITED STATES SUPREME COURT. Republic of Mexico v. Hoffman. In: Volume 324, 1945, p. 35.
} 
however, the courts treated such "suggestions" as binding determinations, and would invoke or deny immunity based upon the decision of the State Department. ${ }^{170}$

Nessa esteira, é importante enaltecer que, o caso Victory Transport v. Comisaría, foi o primeiro caso em que que o tribunal tomou a iniciativa de aplicar imunidade restritiva com base na diferenciação entre atos jure imperii e atos jure gestionis. Este caso foi decidido sob o fundamento de que, o Estado estrangeiro ao concordar em ajuizar uma ação no território do Estado do foro, presume-se que o Estado aquiesceu em ser submetido à jurisdição do tribunal em que a ação foi perpetrada, para que o julgamento possa ser executado. ${ }^{171}$

Entretanto, precisamente pelo fato pelo fato do Departamento de Estado dos Estados unidos ser, precipuamente, um órgão político que trata das relações internacionais, a miscelânea de questões políticas e jurídicas, a cada dia dificultava as tomadas de decisões livres de pressão de governos estrangeiros. Esse foi um dos principais motivos para a criação da Foreign Sovereign Immunities Act (FSIA) em 1976, 172 que prevê a transferência da tomada de decisão do executivo (Departamento de Estado) para o legislativo, objetivando a "despolitização" das decisões acerca da imunidade de jurisdição do Estado estrangeiro. A história legislativa do FSIA aponta que:

[...] principal purpose of this bill is to transfer the determination of sovereign immunity from the executive branch to the judicial branch, thereby reducing the foreign policy implications of immunity determinations and assuring litigants that these often crucial decisions are made on purely legal grounds and under procedures that insure due process. The Department of State would be freed from pressures from foreign governments to recognize their immunity from suit and from any adverse consequences resulting from an unwillingness of the Department to support that immunity [...] U.S. immunity practice would

170 UNITED STATES COURT OF APPEALS. Ninth Circuit. Chuidian v. Philippine National Bank. 912 F.2d 1095. Aug. 29, 1990.

171 UNITED STATES COURT OF APPEALS. Victory Transport Inc v. Comisaría General. New York,1964; Cf. SINCLAIR, S. I. The Law of Sovereign Immunity: Recent Developments. Recueil des Cours de l'Académie de Droit International de La Haye, v. 167, p. 165-166, 1980; BISHOP, W. W. J. New United States Policy Limiting Sovereign Immunity. The American Journal of International Law, v. 47, p. 93-106, 1953; YANG, X. State Immunity in International Law. Cambridge: Cambridge University Press, 2012. p. 16.

172 UNITED STATES. 90 STAT. 2891 - Foreign Sovereign Immunities Act. 94th Congress, 2nd Session, 1976. Public Law 94-583. October, 1976. 28 USC Chapter 97. 
conform to the practice in virtually every other country where sovereign immunity decisions are made exclusively by the courts and not by a foreign affairs agency. ${ }^{173}$

Uma das características definidoras da FSIA dos EUA é a exigência de forma taxativa de nexo territorial juntamente com conexões jurisdicionais. ${ }^{174}$

O caso mais notável na história do direito da imunidade do Estado é, sem dúvida, o caso Empire of Iran, 175 julgado pela Corte Constitucional Federal da Alemanha em 1963. Até o ano de 1945, a Alemanha fazia parte dos Estados que concediam imunidade ilimitadamente, até mesmo aos casos que faziam parte da esfera do direito privado. ${ }^{176} \mathrm{O}$ caso Empire of Iran, é concernente a uma reclamação impetrada por uma empresa de Colônia contra o Irã, com o escopo de cobrar pelo serviço por ela prestado (reparação de sistema de aquecimento) à embaixada Iraniana em Colônia, Alemanha. A quastão, a saber, era, se o Irã pederia ser procesado nas Cortes da Alemanha em relação a uma reclamação direito privado resultante de um ato de direito privado submetido à apreciação da Corte Constitucional Federal. Após um cuidadoso levantamento das práticas internacionais e da doutrina sobre à imunidade Estado, a Corte concluiu que:

The [above] examination of the judicial practice shows that the courts of a considerable number of States, in particular of Italy, Belgium, Switzerland, Austria, France, Greece, Egypt and Jordan, clearly grant immunity to foreign Stat3es only for acts of sovereignty. As to the practice in other States, it is doubtful whether the courts follow the doctrine of unrestricted State immunity as hitherto. In Germany a tendency to restrict State immunity can be seen. On the other hand, the courts especially of England, and the United States, but also of Japan and the Philippines as well as those of the East European States, maintain the view that foreign States should be immune for both sovereign and non-sovereign activities ... From the practice of the courts it

173 UNITED STATES HOUSE OF REPRESENTATIVES. Report №. 94-1487. 1976. Re-printed in: USCCAN 6604, 6606. p. 7; SINCLAIR, S. I. The Law of Sovereign Immunity: Recent Developments. Recueil des Cours de I'Académie de Droit International de La Haye, v. 167, p. 244-245, 1980; BISHOP, W. W. J. New United States Policy Limiting Sovereign Immunity. The American Journal of International Law, v. 47, p. 93-106, 1953; YANG, X. State Immunity in International Law. Cambridge: Cambridge University Press, 2012. p. 16-17.

174 YANG, X. op. cit., p. 17.

175 GERMAN CONSTITUTIONAL COURT. Empire of Iran Case. BVerfGE 16, 272 BvM 1/62. Germany, 30 April 1963; Conferir também: FEDERAL HIGH COURT OF GERMANY. Jurisdiction over Yugoslav Military Mission Case. Germany, 1962; Cf. FOX, H. The law of state immunity. Oxford: Oxford University Press, 2002. p. 75-77

176 GERMAN CONSTITUTIONAL COURT. Empire of Iran Case. BVerfGE 16, 272 BvM 1/62. Germany, 30 April 1963. 
can no longer be deduced, in the face of this situation, that the granting of unrestricted immunity can still today be regarded as a usage followed by the great majority of States in the belief that it is legally obligatory. 177

A Corte Constitucional Federal também examinou tratados bilaterais e multilaterais relevantes e concluiu que tais tratados corroboram a teoria da imunidade restritiva. Ademais, inúmeras tentativas de codificação não dão suporte, de acordo com direito internacional geral, a teoria da imunidade absoluta. ${ }^{178}$

Quanto a distinção entre os atos soberanos e não-soberanos ou atos jure imperii e atos jure gestionis, a Corte Constitucional Federal da Alemanha delineou uma clara diferenciação a intenção do ato praticado pelo Estado e a natureza desse ato, argumentando que é a natureza do ato do Estado que determinará a imunidade:

The distinction between sovereign and non-sovereign State activities cannot be drawn according to the purpose of the State transaction and whether it stands in a recognizable relation to the sovereign duties of the State. For ultimately, activities of State, fi not wholly then to the widest degree, serve sovereign purposes and duties, and stand in a still recognizable relationship to them. Neither should the distinction depend on whether the State has acted commercially. Commercial activities of States are not different in their nature from other non-sovereign State activities.

As a means for determining the distinction between acts jure imperii and jure gestionis one should rather refer to the nature of the State transaction or the resulting legal relationships, and not to the motive or purpose of the State activity It thus depends on whether the foreign State has acted in exercise of its sovereign authority, that is in public law, or like a private person, that is in private law. 179

Apesar das mudanças que estavam a correr no mundo sobre a teoria da imunidade, o Reino Unido até 1972 aplicaram a teoria absoluta da imunidade em todos os casos. Tal posição absolutista estava tão profundamente enraizada que, mesmo em 1984, Lord Diplock ainda usou a frase imunidade soberana absoluta para se referir à imunidade ao abrigo da secção 1 do UK State Immunity Act (SAI) de 1978, que adere manifestamente a teoria restritiva da imunidade, estando a

177 GERMAN CONSTITUTIONAL COURT. Empire of Iran Case. BVerfGE 16, 272 BvM 1/62. Germany, 30 April 1963.

178 SINCLAIR, S. I. The Law of Sovereign Immunity: Recent Developments. Recueil des Cours de l'Académie de Droit International de La Haye, v. 167, p. 182, 1980; YANG, X. State Immunity in International Law. Cambridge: Cambridge University Press, 2012. p. 17-18.

179 GERMAN CONSTITUTIONAL COURT. Empire of Iran Case. BVerfGE 16, 272 BvM 1/62. Germany, 30 April 1963. 
imunidade sujeita a uma série de restrições nesse estatuto. Contudo, em 1972, o Reino Unido assinou a Convenção Europeia sobre a Imunidade do Estado. Apesar d, só vindo a ser ratificada em 1979, tal Convenção deu um impulso significativo para o estabelecimento da imunidade restritiva nos Tribunais do Reino Unido, e levou à promulgação do UK State Immunity Act, que substituiu o common law sobre o tema e deu vigor à Convenção Europeia de 1972. ${ }^{180}$

Os dois casos que marcaram a passagem da adoção da doutrina da imunidade absoluta para a da imunidade restritiva no Reino Unido foram os casos: The Philippine Admiral, apreicado em 1975, e o Trendtex, julgado em 1977, ambos utilizaram a Convenção como suporte. ${ }^{181} \mathrm{O}$ caso Philippine Admiral consistiu em uma reclamação de pagamento pelos reparos de um navio e danos por quebra de contrato. No decorrer do processo o navio permaneceu no porto de Hong Kong, então sob domínio do governo britânico. Já no caso Trendtex estava em causa uma carta de crédito irrevogável emitida pelo Banco Central da Nigéria em Londres para a compra de cimento. Lord Denning salientou, especialmente que:

It was suggested that the original contracts for cement were made by the Ministry of Defence of Nigeria and that the cement was for building of barracks for the army. On this account, it was said that the contracts of purchase were acts of governmental natures, jure imperii, and not of commercial nature, jure gestionis. They were like a contract of purchase of boots for the army. But I do not think that should affect the question of immunity. If a government department goes into the market places If a government department goes into the market places of the world and buys boots or cement - as a commercial transaction - that government department should be subject to all the rules of the market place. The seller is not concerned with the purpose to which the purchaser intends to put the goods.

There is another answer. Trendtex here are not suing on the contracts of purchase. They are claiming on the letter of credit which is an entirely separate contract. It was a straightforward commercial transaction. The letter of credit was issued in London through a London bank in the ordinary course of commercial dealings. It is completely within the territorial jurisdiction of our

\footnotetext{
180 Cf. SINCLAIR, S. I. The Law of Sovereign Immunity: Recent Developments. Recueil des Cours de l'Académie de Droit International de La Haye, v. 167, p. 129-183, 1980; FOX, H. The law of state immunity. Oxford: Oxford University Press, 2002.
}

181 PRIVY COUNCIL OF THE UNITED KINGDOM. The Philippine Admiral. England, 1975; COURT OF APPEAL. Trendtex Trading Corporation v. Central Rank Of Nigeria. England, 1977. Cf. SINCLAIR, S. I. op. cit p. 154-157; FOX, H. op. cit. p. 18. 
courts. I do not think it is open to the Government of Nigeria to claim sovereign immunity in respect of it. 182

O primeiro caso em que Câmara dos Lordes britânica abraçou a doutrina da imunidade restritiva no common law em fatos ocorridos totalmente fora do território do Reino Unido, baseado no princípio de "sister ship", estabelecido no direito marítimo internacional, foi no célebre caso I Congreso del Partido, decidido, em 1981. Nesse caso o autor entrou com pedido de arresto de um navio de comércio de Estado cubano em Sunderland, Reino Unido, para estabelecer jurisdição sobre a reclamação de quebra de contrato em relação às cargas de dois outros navios estatais cubanos. ${ }^{183}$

À medida em que tal desenvolvimento ocorreu, os responsáveis pelo mesmo não tinham em mente os crimes internacionais: a preocupação era bastante voltada para as transações comerciais, principalmente, de modo a afastar a incidência da imunidade quando o Estado estava agindo como uma entidade privada. Esta distinção é resultante de esforços legislativos, incluindo a elaboração de convenções sobre imunidades do Estado, tais como a Convenção Europeia de 1972, relativa imunidade do Estado, adoptada em Basileia, 16 de Maio de 1972, com entrada em vigor na ordem jurídica internacional a 11 de Junho de 1976, após as três ratificações necessárias, serviu ao menos para colocar um fim à noção de absolutismo da imunidade. ${ }^{184}$ Igualmente, pode ser vislumbrado no continente americano um esforço da Organização dos Estados Americanos, a OEA, de legislar, no âmbito dos seus Estados membros, a respeito da matéria, que se iniciou em 1980, por uma decisão de seu Conselho Permanente, a pedido da Assembleia Geral

182 COURT OF APPEAL. Trendtex Trading Corporation v. Central Rank Of Nigeria. England, 1977. Cf. FOX, H. The law of state immunity. Oxford: Oxford University Press, 2002. p.116-117.

183 HOUSE OF LORD. I Congreso del Partido. England, 1983; FOX, H. op. cit. p. 36-39; SINCLAIR, S. I. The Law of Sovereign Immunity: Recent Developments. Recueil des Cours de I'Académie de Droit International de La Haye, v. 167, p. 157-161, 1980; FOX, H. The law of state immunity. Oxford: Oxford University Press, 2002; YANG, X. State Immunity in International Law. Cambridge: Cambridge University Press, 2012. p.18.

184 Esta convenção determina os casos nos quais uma Parte não pode invocar imunidade perante tribunais estrangeiros. Esta situação aplica-se aos casos em que a Parte em questão aceita a jurisdição dos tribunais de outra Parte em processos relativos a contratos de trabalhos, participações em empresas ou associações, atividades industriais, comerciais ou financeira, direito de propriedade sobre imóveis, reparação de danos físicos ou materiais. Cf. DIRECÇÃO-GERAL DA POLÍTICA DE JUSTIÇA. Convenção Europeia sobre a Imunidade dos Estados (STE 074). Portugal, 1979. 
daquela organização regional. Em 1983, o Comitê Interamericano de Juristas apresentaria um Projeto de Convenção Interamericana sobre Imunidades Jurisdicionais dos Estados, que levou em consideração a evolução, em curso, para restringir imunidade do Estado. ${ }^{185}$

Precisamente, este mesmo fenômeno poder ser vislumbrado em outros Estados. Quando as Filipinas em 1958, ${ }^{186}$ a Holanda entre $1968{ }^{187}$ e 1973, ${ }^{188}$ a África do Sul 189 e Cingapura em 1979, 190 o Paquistão, em 1981, 191 a Nova Zelândia, em 1981, ${ }^{192}$ o Canadá 193 e a Dinamarca em 1982, 194 o Zimbábue em 1983, ${ }^{195}$ a Austrália em 1985, 196 Índia ${ }^{197}$ e a Spain ${ }^{198}$ em 1986, o Brasil em 1989,

185 Cf. inter alia. SINCLAIR, S. I. The Law of Sovereign Immunity: Recent Developments. Recueil des Cours de l'Académie de Droit International de La Haye, v. 167, p. 121-217 e 243-266, 1980; FOX, $\mathrm{H}$. The law of state immunity. Oxford: Oxford University Press, 2002. p. 272 e ss; TROOBOFF, P. Foreign State Immunity: Emerging Consensus on Principles. Recueil des Cours Collected Courses of The Hague Academy of International Law, v. 200, p. 252-274, 1986; BISHOP, W. W. J. New United States Policy Limiting Sovereign Immunity. The American Journal of International Law, v. 47, p. 93-106, 1953

186 SUPREME COURT OF THE PHILIPPINES. Harry Lyons v. USA. International Law Reports, v. 88 , p. 711 et seq.

187 HAGUE COURT OF APPEAL. Case of N.V. Cabolent v. National Iranian oil. (1968). International Legal Materials, v. 9, № 1, p. 152-163, January 1970

188 SUPREME COURT OF THE NETHERLANDS. Société Européenne v. Yugoslavia, 26 October 1973. International Law Reports, v. 65, p. 356 et seq., January 1984.

189 SOUTH-AFRICA SUPREME COURT. Inter-Science v. Moçambique, 1979. International Law Reports, v. 64, p. 689 et seq., January 1983; SOUTH-AFRICA SUPREME COURT. Kaffraria Property Co. (Pty) Ltd. v. Government of the Republic of Zambia, 1980. South African Law Reports, v. 2, p. 708 et eq.

190 Através da adopção do Singapore State Immunity Act em 1979; SINGAPORE HIGH COURT. The Hai Hsuan. Singapore, 1950. International Law Reports, v. 17, p. 170 et seq.

191 SUPREME COURT OF PAKISTAN. Qureshi v. Union of Soviet Socialist Republics. Pakistan, 1981. International Law Reports, v. 64, p. 585 et seq.

192 HIGH COURT OF NEW ZEALAND. Marine Steel Ltd v. Government of the Marshall Islands. New Zealand, 1981. International Law Reports, v. 64, p. 539 et seq.; HIGH COURT OF NEW ZEALAND. Marine Steel Ltd v. Government of the Marshall Islands. New Zealand, 1982. International Law Reports, v. 64, p. 562 et seq.

193 O Canada adotou o State Immunity Act em 1982 (espelhado no US FSIA: SUPREME COURT JUDGMENTS. Re Canada Labour Code. Canada, 1992.); contudo, a doutrina da imunidade restritiva já era aplicada desde a década de 60, vide QUEBEC COURT OF APPEAL. Venne v. Democratic Republico of Congo. Canada, 1968. International Law Reports, v. 64, p. 1 et seq.

194 SUPREME COURT OF DENMARK. Embassy of the Socialist Republic of Czechoslovakia v. Jens Nielsen Bygge-Entrepriser. Denmark, 1982. International Law Reports, v. 78, p. 81 et seq.

195 SUPREME COURT OF ZIMBABWE. Barker McCormac Ltd v. Government of Kenya, Zimbabwe, 1983. International Law Reports, v. 84, p. 18 et seq.

196 Com o acolhimento do Australia Foreign States Immunities Act em 1985. QUEENSLAND SUPREME COURT. USA v. Republic of China. Australia. International Law Reports, v. 17, p. 168 et 
199 a Malásia, 200 em 1990, o Israel, 201 em 1997, a Lituânia 202 em 1998, e Portugal 203 em 2002, aderiram à teoria da imunidade restritiva ao adotarem a distinção entre os atos de império e os atos de gestão.

Paralelamente ao desenvolvimento ocorrido nos tribunais pode ser observado a limitação da imunidade e empresas estatais, no território da outra parte, por intermédio de tratados bilaterais. ${ }^{204}$

\subsection{A Convenção das Nações Unidas sobre Imunidade de Jurisdição dos Estados Estrangeiros e seus Bens}

A Convenção das Nações Unidas sobre a Imunidade de Jurisdicionais dos Estados estrangeiros e seus bens (doravante "Convenção") é um documento histórico. Ele marca o constituição definitiva da imunidade restritiva como a doutrina dominante no direito internacional. Assim como o desenvolvimento da teoria de imunidade do Estado, em geral, a evolução da Convenção teve seu quinhão de vicissitudes; passando por um período excepcionalmente longo de elaboração, em

seq.; SUPREME COURT NEW SOUTH WALES. Grunfeld v. United States of America. Australia, 1968. International Law Reports, v. 52, p. 332 et seq.

197 SUPREME COURT OF INDIA. Harbhajan Singh Dhalla vs Union Of India. India, 1986.

198 SUPREME COURT OF SPAIN. Emilio BM v. Embassy of Equatorial Guinea. Spain, 1986. International Law Reports, v. 86, p. 508 et seq.

199 SUPREMO TRIBUNAL FEDERAL. Consulado Geral do Japão v. Ribeiro, Brasil, 2002; SUPREMO TRIBUNAL FEDERAL. República Árabe da Síria v. República Federal do Egito. Brasil, 1982; SUPREMO TRIBUNAL FEDERAL. Représentation commerciale da RDA. Brasil, 1989.

200 SUPREME COURT OF MALAYSIA. Commonwealth of Australia v. Midford (Malaysia) Sdn Bhd and Another. Malaysia, 1990. International Law Reports, v. 86, p. 640 et seq.

201 SUPREME COURT OF ISRAEL. Her Majesty the Queen in Right of Canada v. Edelson and ors. Israel, 1997.

202 SUPREME COURT OF LITHUANIA. Stukonis v. United States Embassy, 5 January 1998, Baltic Yearbook of International Law, v. 2, pp. 270 et seq., 2002.

203 SUPREMO TRIBUNAL DE JUSTIÇA. X v. Israel. Portugal, 2002; TRIBUNAL DA RELAÇÃO DE LISBOA. A v. Embaixada da Áustria (R.). Agravo n. 4107/2005-4. Portugal, 21. set. 2005; TRIBUNAL DA RELAÇÃO DE LISBOA. HM, S.A. (A.) v. Embaixada da República de $\mathbf{X}$ (R.). Portugal, 2011. Portugal assinou a Convenção Europeia de 1972, contudo não ratificou a mesma.

204 YANG, X. State Immunity in International Law. Cambridge: Cambridge University Press, 2012. p. 19. 
decorrência do processo lento e gradual, muitas vezes permeada de controvérsias, pelo qual a teoria da imunidade restritiva passou a ser enraizada no direito internacional.

A Convenção incorpora todos os princípios gerais da imunidade restritiva, como discutido no trabalho ora encetado, ao mesmo tempo apresenta orientações clara a respeito de diversas questões jurídicas ainda em discussão.

O culminar de muitos anos de esforços de codificação em diversos níveis, incluindo deliberações da Comissão de Direito Internacional, e consultas no âmbito da Assembleia Geral das Nações Unidas, representa os avanços e compromissos neste âmbito do direito, que podem vir a ter aceitação geral, além de servir como base precípua para harmonizar a prática de diferentes Estados e para alcançar relativa uniformidade nessa área do direito internacional sempre atormentado por conflitos entre os Estados.

Desde o advento da sua criação 205 a Comissão de Direito Internacional das Nações Unidas (CDI) passou a considerar uma possível codificação da doutrina da imunidade Estado. Em 1948, na preparação da Primeira Sessão da Comissão, a Secretaria das Nações Unidas conduziu uma "pesquisa no direito internacional" e publicou um memorando declarando, em seu parágrafo 52, que:

52- There would appear to be little doubt that the question - in all its Aspects - of jurisdictional immunities of foreign States is capable and in need of codification. It is a question which figures, more than any other aspect of international law, in the administration of justice before municipal courts. The increased economic activities of States in the foreign sphere and the assumption by the State in many countries of the responsibility for the management of the principal industries and of transport have added to the urgency of a comprehensive regulation of the subject. While there exists a large measure of agreement on the general principle of immunity, the divergences and uncertainties in its application are conspicuous not only as between various States but also in the internal jurisprudence of States. This

205 UNITED NATIONS. Statute of the International Law Commission. Adopted by the General Assembly in resolution 174 (II) of 21 November 1947, as amended by resolutions 485 (V) of 12 December 1950, 984 (X) of 3 December 1955, 985 (X) of 3 December 1955 and 36/39 of 18 November 1981. 
applies in particular to that aspect of jurisdictional immunities which arises out of the increase in the economic activities of the State. ${ }^{206}$

Após esses passos iniciais, durante 28 anos, apesar de repetidas indicações da Secretaria, que produziu, em especial um outro "estudo do direito internacional", em 1971, nada foi feito em relação ao tema da imunidade do Estado até 1977, quando, a CDI, em sua vigésima-nona Sessão, recomendou que: "Jurisdictional immunities of States and their property is the one that the Commission recommends for selection in the near future for active consideration by the Commission, bearing in mind its day-to-day practical importance and its suitability for codification and progressive development”. ${ }^{207}$

Posteriormente, a Resolução da Assembleia Geral 32/151 (1977), convidou a CDI a incluir no seu programa de trabalho o tema da imunidade de jurisdição dos Estados e sua propriedade, nos seguintes termos: "The General Assembly invites the International Law Commission, at an appropriate time ... to commence work on the topic of ... jurisdictional immunities of States and their property". ${ }^{208}$

Na sua Trigésima Sessão, em 1978, a CDI decidiu, mediante recomendação de um grupo de trabalho criado para o efeito (um outro grupo de trabalho da CDI seria formado novamente em 1999), para incluir no seu programa de trabalho atual o tópico imunidades jurisdicionais dos Estados e os seus bens. Ademais, solicitou ao Secretário Geral convocasse os governos dos Estados-Membros a apresentarem materiais relevantes sobre o tema, incluindo a legislação nacional, as decisões dos tribunais nacionais e correspondência diplomática e oficial. ${ }^{209}$

\footnotetext{
206 UNITED NATIONS. Document: A/CN.4/1/Rev.1. Survey of International Law in Relation to the Work of Codification of the International Law Commission: Preparatory work within the purview of article 18, paragraph 1, of the of the International Law Commission - Memorandum submitted by the Secretary-General. p. 31, para. 52.

207 UNITED NATIONS. Supplement № 10. A/32/10. Report of the International Law Commission on the work of its twenty-ninth session, 9 May - 29 July 1977, Official Records of the General Assembly, Thirty-second session. p. 310, para. 110.

208 UNITED NATIONS. A/RES/32/151, Resolutions adopted by the General Assembly during its Thirtysecond Session, 19 December 1977. para. 7.

209 UNITED NATIONS. A/CN.4/L.283. Yearbook of the International Law Commission: 1978, vol. II(2). Report of the Working Group on review of the multilateral treaty-making process. Report of the Working Group. p. 152-153, paras. 188 e 190, e Anexo do Chapter VIII-D.
} 
A inclusão do tema da imunidade Estado foi consistentemente confirmado pela Assembleia Geral através de suas resoluções com o passar dos anos. Fato esse, demonstra que a codificação do direito da imunidade do Estado tem gozado um apoio considerável ao longo do processo. ${ }^{210}$

Em 1991, em sua quadragésima terceira Sessão, o CDI finalmente concluiu um conjunto de vinte e dois Projetos de Artigos (Draft Articles) e apresentou-as, juntamente com os comentários, à Assembleia Geral, recomendando a realização de uma conferência internacional de plenipotenciários para examinar os Projetos de Artigos sobre as imunidades jurisdicionais dos Estados e dos seus bens e concluir uma convenção sobre o assunto. ${ }^{211} \mathrm{~A}$ Assembleia Geral manifestou devidamente a sua apreciação para a conclusão dos Projetos de Artigos sobre imunidades jurisdicionais dos Estados e dos seus bens. ${ }^{212}$

É imperioso enaltecermos que, a Assembleia Geral decidiu instaurar em sua quadragésima sétima sessão um grupo de trabalho aberto na Sexta Comissão Legal para analisar:

(a) Issues of substance arising out of the draft articles, in order to facilitate a successful conclusion of a convention through the promotion of general agreement;

(b) The question of the convening of an international conference, to be held in 1994 or subsequently, to conclude a convention on jurisdictional immunities of States and their property. ${ }^{213}$

O grupo de trabalho da Sexta Comissão realizou duas sessões: uma em 1992 e outra em 1993. O mesmo considerou as seguintes questões essenciais: (1) a definição dos termos "Estado" e "transação comercial", incluindo a questão do

210 YANG, X. State Immunity in International Law. Cambridge: Cambridge University Press, 2012. p.447

211 UNITED NATIONS. Document. A/46/10. Yearbook of the International Law Commission: 1991, vol. II(2). Report of the International Law Commission on the work of its forty-third session, 29 April-19 July 1991. Official Records of the General Assembly, Forty-sixth session, Suplement No. 10. Chapter II, paras. 23, 25 e 28. Disponível em: <http://legal.un.org/ilc/documentation/english/A_46_10.pdf >

212 UNITED NATIONS. A/RES/46/54. Resolutions adopted by the General Assembly at its 46th session, 2002. para. 2; UNITED NATIONS. A/RES/46/55. Resolutions adopted by the General Assembly at its 46th session. para.1.

213 UNITED NATIONS. A/RES/46/55. Resolutions adopted by the General Assembly at its 46th session. para. 4. 
critério para determinar se um contrato ou transação caracterizam uma "transação comercial", (2) a questão da distinção legal entre um Estado e de algumas das suas entidades, em matéria de imunidade do Estado, (3) contratos de trabalho, (4) a questão da imunidade em matéria de medidas de coerção. Os debates nessas sessões focaram, precipuamente, no critério para determinar uma transação comercial, na situação jurídica das entidades do Estado e nas medidas de coerção. 214

De modo geral, os Estados que participaram da sexta consulta Comissão evidenciaram uma visão altamente favorável aos projetos de artigos da Comissão de Direito Internacional, apreciando-as como um compromisso equilibrado para acomodar várias posições, e capaz de servir como uma base sólida de um instrumento internacional que representará segurança e uniformidade em uma área do direito que é turbulento. ${ }^{215}$

Sublinhe-se que, uma vez que todos os Estados abraçaram os projetos de artigos CDI, ou seja, nenhum Estado defendeu a doutrina da imunidade absoluta. Assim, pode-se concluir que, no momento em que a CDI apresentou o seu projeto à Assembleia Geral da ONU em 1991, o princípio geral da imunidade restritiva havia sido universalmente aceito, pelo menos no plano internacional, como um fato constituído e um direito estabelecido. ${ }^{216}$

Em contrapartida, apesar de haver um consenso geral de que 0 desenvolvimento de um instrumento internacional era urgente, não houve, entanto, nenhum acordo a respeito de quando uma conferência internacional deveria ser realizada. Contudo, a opinião predominante era a favor de uma conferência

\footnotetext{
214 UNITED NATIONS. A/C.6/47/L.10. Report of the Working Group, 1992. paras. 5, 15-20, 21-25, 31-34; UNITED NATIONS. A/C.6/48/L.4. Report of the Working Group, 1993. para. 6; UNITED NATIONS. A/C.6/48/SR.29. General Assembly Official Records. Forty-eighth Session, Summary Record of the 29th meeting, 15 November 1993, para. 15; UNITED NATIONS. A/C.6/49/L.2. Report of the Chairman of the informal consultations held in the Sixth Committee, Part II, 1994. para. 47; UNITED NATIONS. A/C.6/49/SR.32. General Assembly Official Records, Forty-ninth Session, Summary Record of the 32nd meeting, 11 November 1994. para. 15; Para mais detalhes vide YANG, $X$. State Immunity in International Law. Cambridge: Cambridge University Press, 2012. p. 448 ss.

215 Cf. YANG, X. op. cit. p. 449; HAFNER, G.; ULRIKE, K. The United Nations Convention on jurisdictional immunities of states and their property. Netherlands Yearbook of International Law, $v$. XXXV, p. 3-49, December 2004.

216 YANG, X. op. cit. p. 449.
} 
diplomática, todavia, essa conferência só deveria ser convocada quando todas as questões pendentes de princípio tiverem sido dirimidas e um razoável consenso alcançado, deste modo, as consultas deveriam continuar (de preferência na forma de um grupo de trabalho) para um eventual consenso ser obtido, uma vez que uma conferência falha poderia gerar mais danos aos esforços de codificação do que nenhuma conferência. De qualquer forma, a "conferência internacional" não seria realizada até 2004, treze anos após a apresentação dos projetos de artigos da CDI para a Assembleia Geral, em 1991. ${ }^{217}$

A Assembleia Geral adotou a Convenção das Nações Unidas sobre as Imunidades Jurisdicionais dos Estados e seus bens na Resolução A/RES/59/38 de 2 de dezembro de 2004 sem voto, assim sendo, foi alcançado com sucesso um agitado e moroso processo de codificação. ${ }^{218}$

A Convenção da ONU engloba todos os princípios gerais atualmente aceitos sobre a imunidade do Estado. Estes estão amplamente em conformidade com os atuais estatutos nacionais sobre a imunidade. Esses princípios incluem ${ }^{219}$ :

(1) Os Estados gozam de imunidade, como um princípio de direito internacional consuetudinário (preâmbulo, parágrafo $1^{\circ}$ ).

(2) Em princípio os Estados estão imunes a processos perante os tribunais nacionais estrangeiros (artigo $5 \stackrel{\circ}{\text { ) }}$, sujeito a exceções claramente definidos concernentes aos processos judiciais nos quais os Estados não podem invocar imunidade (artigos 7-17).

(3) Para que um tribunal possa negar a imunidade, o mesmo deve, primeiramente, ter competência. Assim, a conexão jurisdicional é estabelecida em todos os artigos que se ocupam dos casos nos quais a imunidade de Estado não

\footnotetext{
217 YANG, X. State Immunity in International Law. Cambridge: Cambridge University Press, 2012. p. 449-550; Cf. HAFNER, G.; ULRIKE, K. The United Nations Convention on jurisdictional immunities of states and their property. Netherlands Yearbook of International Law, v. XXXV, p. 3-49, December 2004.

218 Cf. HAFNER, G.; ULRIKE, K. op. cit. p. 3-49.

219 Para mais detalhes vide HAFNER, G.; ULRIKE, K. op. cit. p. 3-49.
} 
podem ser invocada. Nesse diapasão, Hafner Gerhard e Köhler Ulrike assinalam que:

\begin{abstract}
A prerequisite for the question of whether a state enjoys immunity is the existence of jurisdiction of the court. Therefore, Article 10 first requires that the transactions envisaged, in accordance with the rules of private international law, fall within the jurisdiction of a court of another state. Such jurisdiction could be based, inter alia, on the place of conclusion of the contract, the place where the obligations arising from the contract are to be performed, or on the basis of the nationality of one of the contracting parties. In this context, Articles 11 until 17 refer to the existence of the jurisdiction of the court by using the formula of the 'court of another state which is otherwise competent' in the relevant proceeding. ${ }^{220}$
\end{abstract}

Além disso, vários artigos especificamente exigem um nexo territorial. Artigo 11 nega a imunidade com relação aos contratos de trabalho "realizado ou que se deveria realizar, no todo ou em parte, no território desse outro Estado". O artigo 12 aplica-se se à processo relacionado com uma "indenização pecuniaria, em caso de morte ou de ofensa à integridade física de uma pessoa, ou em caso de dano ou perda de bens materiais causados por um ato ou omissão alegadamente atribuído ao Estado, se esse ato ou omissão ocorreu, no todo ou em parte, no território desse outro Estado e se o autor do ato ou omissão se encontrava nesse território no momento da prática do ato ou omissão". O artigo 19 limita as medidas de execução contra os bens de um Estado na ausência de renúncia ou reserva, se os bens "estão situados no território do Estado do foro".

(4) A imunidade que os Estados estrangeiros gozam abarcam duas imunidades distintas, nomeadamente, a imunidade de jurisdição e a imunidade de execução. Quando um Estado renunciar a imunidade de jurisdição não está renunciando também a imunidade de execução. Para cada uma dessas modalidades de imunidades é necessaria uma renúncia distinta, ou seja, a renuncia de um não gera a renuncia da outra. ${ }^{221}$

(5) Portanto, a questão da execução é tratada separadamente da questão do julgamento.

220 Cf. HAFNER, G.; ULRIKE, K. The United Nations Convention on jurisdictional immunities of states and their property. Netherlands Yearbook of International Law, v. XXXV, p. 25-26, December 2004.

221 YANG, X. State Immunity in International Law. Cambridge: Cambridge University Press, 2012. p. 455. 
Nessa esteira, é mister elucidarmos os casos que não estão ao abrigo da Convenção, ou melhor, que foram evitados pela mesma, apesar de serem de extrema acuidade.

A Convenção esquivou-se de questões como a imunidade do Estado em relação às violações dos direitos humanos, a noção de jus cogens e seu possível efeito sobre a imunidade do Estado, imunidade dos agentes do Estado concernentes ao processo penal, a jurisdição extraterritorial, e o status das forças armadas estrangeiras. ${ }^{222}$ Sintetizando, a Convenção das Nações Unidas deixou intacto esses aspectos da legislação que ainda não estão "maduros" para codificação; concentrando-se apenas em áreas onde a probabilidade do consenso ser alcançado é maior, assegurando a perspectiva de ganhar ampla aceitação.

No seu conjunto, a Convenção da ONU incorpora a cristalização de todos os aspectos tradicionais da direito da imunidade do Estado, mas mantem-se alheio aos desenvolvimentos recentes (ou tentativas frustradas em decorrência desse fato) noutros âmbitos, especialmente no dos litígio de direitos humanos transnacionais. Em outras palavras, a Convenção da ONU permanece estritamente dentro dos limites tradicionais, que foram definidos e delimitados precipuamente por casos que envolvem transações comerciais e afins, e estão firmemente enraizados no princípio fundamental da competência territorial. ${ }^{223}$

A história conturbada dos esforços de codificação que levam à criação da Convenção das Nações Unidas vividamente evidencia os meandros no desenvolvimento da atual doutrina restritiva da imunidade. A Convenção é uma declaração oficial do quão longe os Estados estão dispostos a ir no exercício da jurisdição sobre os Estados estrangeiros e em renunciar a sua própria imunidade. Ela representa a cristalização de inúmeros princípios desenvolvidos na esfera do direito "tradicional" e marca a vitória final da doutrina da imunidade restritiva. Em seu conteúdo, no entanto, continua fielmente dentro dos limites dessa doutrina conforme

${ }^{222}$ Cf. DIXON, M. Textbook on international law. 5a . ed. Oxford: Oxford University Press, 2005.

223 YANG, X. State Immunity in International Law. Cambridge: Cambridge University Press, 2012. p. 456 et seq. 
desenvolvida por órgão jurisdicionais para lidar com disputas comerciais, principalmente entre indivíduos e Estados estrangeiros.

A Convenção constitui um marco num duplo sentido: ela representa o fim de um século de hostilidade entre a doutrina da imunidade restritiva e a da imunidade (quase) absoluta; e, a sua consolidação, indica áreas onde novos desenvolvimentos são certamente de se esperar. Destarte, a história da imunidade Estado não terminou com a Convenção das Nações Unidas: ela recomeçou, com uma frente diferente.

\section{A IMUNIDADE DE JURISDIÇÃO DO ESTADO ESTRANGEIRO E AS VIOLAÇÕES AOS DIREITOS HUMANOS}

Para melhor entendermos sobre a imunidade de jurisdição e as violações direitos humanos, insta primeiramente elucidar o que se entende por "direitos humanos" e as suas "violações", o que, sintomaticamente aventa a questão a saber se o Estado poderá gozar da imunidade nos casos envolvendo tais violações, que tipo (s) de litígio seriam esses. Mais importante ainda, uma vez que a imunidade significa basicamente isenção de jurisdição territorial do Estado foro, deve-se especificar onde as supostas transgressões ocorreram. Contudo, no trabalho ora encetado iremos focar nas questões sobre a imunidade, deixando os "direitos humanos" e seus "violações" ao entendimento comum. A jurisdição do tribunal será inquestionavelmente no lugar onde as alegadas violações se deram, no foro desse Estado.

No que diz respeito à questão da imunidade, na medida em que um dos direitos humanos reivindicados for sobre uma indemnização pecuniária concernente à lesões corporais ocorridas no território desse Estado, já é assunto abarcado pelas exceções da imunidade, especificamente sobre danos causados a pessoas e bens 
segundo a legislação vigente. ${ }^{224}$ Uma ação criminal contra o indivíduo que perpetrou tal infração (cometido dentro do terrotório do Estado foro) também está coberto pelas legislações atuais dos direitos humanos e do diereito penal. $O$ problema, no entanto, vem a luz quando uma ação é instaurada contra o suposto agressor, e o mesmo não estiver dentro das fronteiras do Estado foro e/ou em relação a violações dos direitos humanos perpetradas fora desse território. Assim, o cerne da questão, quando trata-se da imunidade em matéria de violações de direitos humanos, é o exercício da jurisdição extraterritorial ea correspondente imunidade. No passo em que o direito internacional se encontra nos dias atuais, existem obstáculos intransponíveis para um exercício ideal e sem entraves de jurisdição (e negação da imunidade) no que tange às violações dos direitos humanos praticados no estrangeiro.

\subsection{Jurisdição Territorial}

Nesse passo, é mister tecermos acerca da conexão que existe entre a jurisdição e a imunidade, isso porque, só podemos tratar da imunidade uma vez que a jurisdição seja estabelecida.

Apesar de sua importância, a jurisdição, nos casos que envolvem a imunidade do Estado, tem sido deixado de lado e em grande parte obscurecida pela discussão sobre a imunidade que domina esses casos. A ausência de discussão sobre a existência de jurisdição nos casos que envolvem a questão da imunidade do Estado, onde os tribunais normalmente voltam-se imediatamente para essa questão em especial, é devido ao fato de que nesses casos inexiste a dúvida quanto jurisdição. Em outras palavras, apenas com raras exceções, que serão discutidas a seguir, os casos comuns sobre a imunidade envolvem demandas que, ou ocorreram dentro dos limites do território local, ou possuem uma ligação territorial em relação à jurisdição doméstica. Desse modo, a perquisição da jurisdição é facilmente

\footnotetext{
${ }^{224}$ Artigo 12 da Convenção o internacional sobre as imunidades jurisdicionais dos Estados e dos seus bens.
} 
esquecida, uma vez que é aceita como uma premissa dada, não há necessidade de provar a sua existência. Fato este que, torna possível a discussão da imunidade antes dela ser estabelecida. ${ }^{225}$

Sublinhe-se que, uma vez que a matéria do caso surgiu dentro dos limites da jurisdição local, tal fato pode não representar nenhuma dificuldade, contudo, quando um tribunal é chamado a julgar um caso que requer o exercício da jurisdição extraterritorial, isso acarretara na junção da jurisdição e da imunidade, de modo que o tribunal poderá cometer o erro de equiparar a negação da imunidade à determinação da jurisdição. Quer isso dizer que, o tribunal poderá afirmar a sua jurisdição, quando na realidade a mesma nem se quer existe. Isso ocorre porque o tribunal pode simplesmente se esquecer de que ele deve possuir jurisdição para que possa discutir a questão da imunidade; já que o direito tradicional da imunidade do Estado limitou-se a lidar sobre assuntos que surgem dentro dos limites territoriais dos Estados locais.

Entretanto, o rápido desenvolvimento do direito internacional dos direitos humanos, em que a noção de jurisdição extraterritorial desempenha um papel fundamental, e com ele o aumento do número de reclamações com base em eventos que ocorrem muito além das fronteiras nacionais do Estado foro, evidencia que a questão da jurisdição deve ser apreciada pelos tribunais em primeiro lugar para que então eles possam debater sobre a imunidade. ${ }^{226}$

À vista disso, é necessário tratar a jurisdição e imunidade como duas questões distintas, sendo que ambas terão de ser estabelecidas por uma tribunal nacional antes que o mesmo possa afirmar jurisdição sobre questões que ocorrem em países estrangeiros. Tal como o Tribunal Internacional de Justiça acertadamente sublinhou no caso Arrest Warrant:

[...] the rules governing the jurisdiction of national courts must be carefully distinguished from those governing jurisdictional immunities: jurisdiction

\footnotetext{
225 Cf. YANG, X. State Immunity in International Law. Cambridge: Cambridge University Press, 2012. p. 424 et seq.

226 Ibidem.
} 
does not imply absence of immunity, while absence of immunity does not imply jurisdiction. ${ }^{227}$

Assim, apesar da "ausência de jurisdição" e "imunidade" serem frequentemente utilizadas indistintamente, por conveniência, é errôneo doutrinalmente trata-los como sinônimos. Elucidando o que foi dito: a "imunidade" na verdade comprova a existência da jurisdição por ser exceção da mesma. Em outras palavras, a imunidade significa a presença de jurisdição, em vez da ausência ou falta dela. Ao asseverar-se que não há imunidade em um caso, não quer dizer que a jurisdição não existe, isso só significa que o tribunal tem jurisdição, mas não pode exercê-la: a imunidade impede o exercício de uma jurisdição que, em outra conjuntura seria exercível. ${ }^{228}$

A territorialidade do direito da imunidade Estado significa que, se a violação ocorre dentro das fronteiras do Estado foro, a jurisdição poderá, assim, ser exercida, mas, se ela ocorre fora do território do Estado doméstico, a jurisdição não pode ser determinada com base unicamente na ilegalidade. Nesse caso a jurisdição deve ser acertada em consonância com as normas e princípios do direito internacional concernentes à jurisdição extraterritorial. Em que nenhum tribunal pode ser mostrado para existir, a questão da imunidade não se coloca em primeiro lugar. Sublinhe-se que, se a jurisdição inexistir a questão da imunidade não poderá nem ao menos ser aventada. ${ }^{229}$

Apesar do tema da territorialidade da imunidade do Estado ser de imensurável importância para os casos relativos a violações de direitos humanos, o direito internacional atual está longe de dirimir essa questão, consequentemente, novos estudos acerca o tema são altamente necessários. ${ }^{230}$

\footnotetext{
227 INTERNATIONAL COURT OF JUSTICE. Arrest Warrant of 11 April 2000 (Democratic Republic of the Congo v. Belgium). para. 59.

228 YANG, X. State Immunity in International Law. Cambridge: Cambridge University Press, 2012. p. $425-426$.

229 Ibidem. p. 426.

${ }^{230}$ A CIJ decidiu, em 2006, incluir o tema da "Extraterritorialidade Jurisdicional" no seu programa de trabalho. Vide UNITED NATIONS. Supplement No. $10 \mathrm{~A} / \mathbf{6 1 / 1 0}$. Report on the work of its fifty-eighth session. 1 May to 9 June and 3 July to 11 August 2006. paras. 22, 257, 260 and Anexo E.
} 


\subsection{As normas peremptórias do Direito Internacional (jus cogens) podem afastar a aplicação da regra internacional consuetudinária relativa à imunidade de jurisdição?}

A posição do indivíduo no direito internacional evoluiu consideravelmente nas últimas décadas. A legislação reconheceu o indivíduo como sujeito de direito internacional detentor de uma série de direitos fundamentais e remédios caso uma dessas prerrogativas serem violadas. Ao mesmo tempo, a perspectiva da aplicação internacional desses direitos ainda é incerta, já que o desenvolvimento de mecanismos de adjudicação ainda encontra-se em fase embrionária. Consequentemente, as vítimas de violações de direitos humanos internacionais começaram a explorar outros meios para a obtenção de reparação, nomeadamente recorrendo a ações civis em tribunais nacionais. No entanto, é especificamente a nível nacional que os seus esforços para obter reparação pela violação do direito internacional são susceptíveis de encontrar como obstáculo da doutrina da imunidade do Estado.

Com base no reconhecimento do novo status do indivíduo no âmbito do direito internacional, a pressão sobre os Estados para porem termo aos obstáculos que impedem as vítimas de violações de obterem reparações tem aumentado consideravelmente. Instrumentos, não vinculantes, que enfatizam o dever dos Estados de disporem de remédios para as vítimas de violações do direito internacional têm-se multiplicado, delineando uma nova perspectiva, orientada para vítima, a ser adotada pela comunidade internacional. ${ }^{231}$

Com a entrada em vigor do Estatuto do Tribunal Penal Internacional de Roma, em 2002, reiterou-se que os indivíduos podem ser penalmente responsáveis por

231 Cf. UNITED NATIONS. A/RES/60/147. Preambulo da Assembléia Geral; UNITED NATIONS. A/RES/60/147. Basic Principles and Guidelines on the Right to a Remedy and Reparation for Victims of Gross Violations of International Human Rights Law and Serious Violations of International Humanitarian Law. Resolution adopted by the General Assembly, 21 March 2006; KNUCHEL, S. State Immunity And The Promise Of Jus Cogens. Northwestern Journal of International Human Rights, v. 9, p. 149-183, 2011. 
crimes internacionais. Para "pôr fim à impunidade", ${ }^{232}$ o Estatuto de Roma salienta que:

[...] a qualidade oficial de Chefe de Estado ou de Governo, de membro de Governo ou do Parlamento, de representante eleito ou de funcionário público em caso algum eximirá a pessoa em causa de responsabilidade criminal, [...] nem constituirá de per si motivo de redução da pena. ${ }^{233}$

Além disso, o Estatuto de Roma inclui a notável inovação de permitir a vítima a tomar parte no processo e obter algum tipo de reparação para o seu dano.

Em concomitância a esses desenvolvimentos, o entendimento de que a imunidade é um empecilho injusto para que se possa alcançar reparações as violações do direito internacional tem se expandindo. Tal percepção foi ainda nutrida pelo reconhecimento progressivo do status superior de um certo número de normas internacionais, consideradas possuidoras de um peso normativo superior. Estas normas, conhecidas como normas imperativas de direito internacional ou jus cogens, servem como um controle sobre as ações dos Estados, que devem aderi-las em quaisquer circunstâncias. Conforme será ventilado a seguir, a classificação mais elevada na hierarquia emergente das normas internacionais foi apresentada como mais um motivo para afastar a imunidade soberana em reclamações decorrentes as referidas violação.

A acepção de jus cogens foi articulada, manifestamente, no direito internacional pela primeira vez na Convenção de Viena sobre direito dos tratados, de 23 de maio de 1969. ${ }^{234}$ Já no preâmbulo os Estados Partes afirmam que "Tendo presentes os princípios de direito internacional consignados na Carta das Nações Unidas, tais como os princípios respeitantes à igualdade dos direitos dos povos e ao seu direito à autodeterminação, à igualdade soberana e à independência de todos os Estados, à não ingerência nos assuntos internos dos Estados, à proibição da

232 ORGANIZAÇÃO DAS NAÇÕES UNIDAS. Preâmbulo do Estatuto de Roma do Tribunal Penal Internacional.

233 Idem. Artigo $27^{\circ}$.

234 Para mais detalhes vide PETSCHE, M. Jus Cogens as a vision of the International Legal Order. Penn State International Law Review, v. 29, p. 233-273, 2010-2011; JORGENSEN, N. H. B. The responsibility of states for international crimes. Oxford: Oxford University Press, 2000. p. 85-92. 
ameaça ou do emprego da força e ao respeito universal e efetivo dos direitos do homem e das liberdades fundamentais para todos." 235

Conforme o artigo 53, "É nulo todo o tratado que, no momento da sua conclusão, seja incompatível com uma norma imperativa de direito internacional geral. Para os efeitos da presente Convenção, uma norma imperativa de direito internacional geral é uma norma aceite e reconhecida pela comunidade internacional dos Estados no seu todo como norma cuja derrogação não é permitida e que só pode ser modificada por uma nova norma de direito internacional geral com a mesma natureza". ${ }^{236}$

Por outro lado o artigo 64 estabelece que "Se sobrevier uma nova norma imperativa de direito internacional geral, qualquer tratado existente em conflito com essa norma torna-se nulo e extingue-se". ${ }^{237}$ Charles de Visscher "sublinhou que aquele que invocar uma regra de jus cogens em relação a este artigo suportará um ônus de prova considerável." 238

Os dois artigos acima citados estabelecem uma verdadeira hierarquia entre as normas imperativas e as demais; de maneira que nenhuma delas estabelece uma nova categoria de fontes formais de Direito Internacional. ${ }^{239}$ Contudo a CDI inovou ao recomendar, por unanimidade, que a violação das normas imperativas fosse sancionada pela nulidade dos tratados. 240 Tal como escrevem Nguyen Quoc Dinh, Patrick Daillier e Alain Pellet, essa observação faz ressaltar o verdadeiro alcance da obra da CDI, reconhecida pela Conferência que aprovou o projeto de Convenção: o próprio fundamento do direito internacional foi posto em questão. ${ }^{241}$

\footnotetext{
235 ORGANIZAÇÃO DAS NAÇÕES UNIDAS. Convenção de Viena sobre o Direito dos Tratados, assinada em 23 de Maio de 1969.

236 ORGANIZAÇÃO DAS NAÇÕES UNIDAS. op. cit.

237 ORGANIZAÇÃO DAS NAÇÕES UNIDAS. op. cit.

238 VISSCHER, C. apud BROWNLIE, I. Princípios de direito internacional público. Lisboa: Fundação Calouste Gulbenkian, 1997. p. 538

239 NGUYÊN, Q. D.; DAILLIER, P.; PELLET, A. Direito internacional público. Lisboa: Fundação Calouste Gulbenkian, 2003. p. 125.

240 NGUYÊN, Q. D.; DAILLIER, P.; PELLET, A. op. cit.

241 NGUYÊN, Q. D.; DAILLIER, P.; PELLET, A. op. cit.
} 
Frente à dificuldade de estabelecer a distinção entre as normas imperativas das demais, a CDI, em seu relatório, citou alguns exemplos de tratados que derrogam o jus cogens: tratado que vislumbra o emprego da força em violação dos princípios da Carta da O.N.U., tratado que organiza o tráfico de escravos, a pirataria ou o genocídio, tratados que violam os direitos humanos. ${ }^{242}$

Nessa esteira é imperioso aventar a exceção que a Convenção de Viena de 1969 consagra em matéria de extinção ou suspensão da execução de um tratado em decorrência de sua violação, sendo ela a regra geral segundo a qual uma violação substancial de um tratado bilateral, por uma das Partes, autoriza a outra Parte a invocar a violação como motivo para fazer cessar a vigência do tratado ou para suspender a sua aplicação, no todo ou em parte não se aplica às disposições sobre proteção da pessoa humana contidas em tratados de caráter humanitário. ${ }^{243}$ Ademais, a Convenção estabelece que é nulo todo o tratado cuja conclusão tenha sido obtida pela ameaça ou pelo emprego da força, em violação dos princípios de direito internacional consignados na Carta das Nações Unidas. ${ }^{244}$

Michel Virally entende que a "norma imperativa" e a "norma obrigatória" não são unívocas: todas as normas do direito internacional são, com efeito, obrigatórias para os Estados, o que significa que sua violação constituiria um ato ilícito. Entretanto, o mesmo nota que as normas obrigatórias de direito internacional podem em geral ser objeto de derrogação por vontade das partes. Elas compõem o que normalmente se denomina direito dispositivo, enquanto que o jus cogens se caracteriza precisamente pelo fato de que suas normas não podem ser derrogadas nas relações mútuas entre dois ou mais Estados. Ou seja, um Estado não pode renunciar aos direitos criados pelas normas de jus cogens. O mesmo doutrinador, ainda, estima que a situação que resulta da existência do jus cogens apresenta um

\footnotetext{
242 UNITED NATIONS. A/CN.4/SER.A/1966/Add.I. Yearbook of The International Law Commission. vol. II, 1966. p. 207; De acordo com Petsche "those examples do not remove basic interpretative obstacles caused by tautology (a peremptory norm is a norm that is recognized as peremptory) and overall - though deliberate and probably unavoidable - vagueness." PETSCHE, M. Jus Cogens as a vision of the International Legal Order. Penn State International Law Review, v. 29, p. 240-241, 2010-2011.
}

243 ORGANIZAÇÃO DAS NAÇÕES UNIDAS. Convenção de Viena sobre o Direito dos Tratados, assinada em 23 de Maio de 1969. Artigo 60ำ 5.

${ }^{244}$ ORGANIZAÇÃO DAS NAÇÕES UNIDAS. op. cit., artigo 52․ 
caráter excepcional no estado atual do desenvolvimento da sociedade internacional, porque impõe uma limitação à autonomia da vontade dos Estados, isto é, à sua liberdade contratual, considerada tradicionalmente como absoluta. ${ }^{245}$

No entanto, há opiniões divergentes na doutrina quanto à utilidade do Jus Cogens, e até mesmo quanto à sua existência. De acordo com Prosper Weil o sistema normativo internacional é, e sempre foi nada mais do que um instrumento para a realização de um objetivo triplo: assegurar a cada Estado o respeito a sua soberania dentro de sua fronteira, e regular relações interestatais de coexistência e cooperação. Nesse sentido, o autor escreve que: "la difficulté, confinant à l'impossibilité, d'identifier les règles de jus cogens; le risque qu'elle comporte pour la stabilité des traités; son incompatibilité essentielle, viscérale presque, avec la structure du système international." O mesmo entende que a normatividade internacional possui fraquezas conceituais, advindas do fenômeno da graduação normativa, resultado da distinção que se deve fazer não mais entre o que é e o que não é norma, mas sim da diferenciação entre normas ordinárias e normas imperativas (jus cogens). ${ }^{246}$ Outros doutrinadores, em especial Sereni e Suy, opunham-se a submissão dos tratados às normas morais sob a argumentação de que as condições para a existência do jus cogens, ou seja, de uma ordem pública internacional, ainda não se materializou. ${ }^{247}$

Urge, desse modo, tecer algumas observações. De acordo com o ilustre doutrinador Antônio Augusto Cançado Trindade, o alcance das normas de jus cogens não se limita ao direito dos tratados:

Apesar de que as duas Convenções de Viena sobre Direito dos Tratados
(artigos 53 e 64) consagram a função do jus cogens no domínio próprio do
direito dos tratados, parece-nos uma consequência inelutável da própria
existência de normas imperativas do direito internacional não se limitarem
estas às violações resultantes de tratados, e se estenderem a toda e

245 VIRALLY, M. Réflexions sur le "jus cogens. Annuaire français de droit international, p. 5-29, 1966.

246 WEIL, 1987 apud SALCEDO, J. A. C. Reflections on the Existence of a Hierarchyof Norms in International Law. European Journal of International Law, p.590, 1997.

247 PETSCHE, M. Jus Cogens as a vision of the International Legal Order. Penn State International Law Review, v. 29, p. 239, 2010-2011. 
qualquer violação, inclusive as resultantes de toda e qualquer ação e quaisquer atos unilaterais dos Estados. ${ }^{248}$

Ad argumentandum, o âmbito das normas imperativas não se restringe ao direito dos tratados. Assim como um ato internacionalmente ilícito, a violação de uma regra de jus cogens envolve a responsabilidade do próprio Estado (este ponto foi esclarecido no Projeto de artigos da CDI sobre Responsabilidade dos Estados por Atos Internacionalmente llícitos adotado por uma resolução da Assembleia Geral da ONU em 2001), bem como a responsabilidade individual do agente. ${ }^{249}$ Além disso, pelo fato da violação de normas imperativas ofender os interesses da Comunidade no seu todo, o princípio de que os estados podem estender sua jurisdição sobre tais violações, mesmo quando eles forem cometidos extraterritorialmente passou a ser afirmado por ambos os instrumentos internacionais e legislações nacionais. ${ }^{250}$

De acordo com o direito internacional, a imunidade do Estado estrangeiro em relação a atos praticados no exercício da autoridade soberana (acta jure imperii) parece ser a regra, mesmo quando esses atos são cometidos em violação de uma norma que tem o caráter de jus cogens.

Apesar da questão da existência ou inexistência de imunidade no caso de violação de normas jus cogens de direito internacional perpetrada por um Estado ter sido aventado durante a elaboração da Convenção das nações unidas sobre as imunidades jurisdicionais dos estados e dos seus bens, o Grupo de Trabalho estabeleceu que um projeto de codificação sobre o tema não poderia ser engajado,

248 TRINDADE, A. A. C. Tratado de direito internacional dos direitos humanos. Porto Alegre: Sérgio Antonio Fabris Editor, v. II, 1999. p. 416.

249 UNITED NATIONS. Draft Articles on Responsibility of States for Internationally Wrongful Acts. Resolution 56/83 of 12 December 2001, and corrected by document A/56/49. art. 26 e pt. 2, ch. III (on "Serious breaches of obligations under peremptory norms of general international law.").

250 UNITED NATIONS. Convention against Torture and Other Cruel, Inhuman or Degrading Treatment or Punishment. Dec. 1984; UNITED NATIONS. A/RES/39/46. General Assembly, Convention against Torture and Other Cruel, Inhuman or Degrading Treatment or Punishment: resolution / adopted by the General Assembly, 10 December 1984; INTERNATIONAL COMMITTEE OF THE RED CROSS. Geneva Convention Relative to the Treatment of Prisoners of War. 12 August 1949. arts. 49, 50, 129, 146, Aug. 12, 1949, 75 U.N.T.S. 135. 
pelo fato do mesmo não estar maduro o suficiente. ${ }^{251} \mathrm{O}$ presidente do Grupo de Trabalho, professor Gerhard Hafner, asseverou que:

Some criticism has been levelled at the Convention on the ground that it does not remove immunity in cases involving claims for civil damages against States for serious violations of human rights. This issue was raised in the ILC and it was dropped. It was raised again in the UN General Assembly and it was dropped because, in the light of the Al Adsani case and other developments, it was concluded that there was no clearly established pattern by States in this regard. ${ }^{252}$

Entretanto, não pode-se inferir que o silêncio da Convenção soluciona a questão. Pelo contrário, o Grupo de Trabalho advertiu que os recentes desenvolvimentos sobre o tema não devem ser ignorados. Apesar da imunidade ser concedida na maioria dos casos, os tribunais nacionais tem demonstrado um maior apoio ao argumento de que a imunidade deve ser negado em caso de morte ou danos de indivíduos resultantes de atos de um Estado que violem as normas de direitos humanos com a natureza de jus cogens, precipuamente a proibição da tortura. Ou seja, um Estado não pode invocar imunidade em relação às graves violações de direitos humanos que tenham a natureza de jus cogens. ${ }^{253}$

Esta evolução emergente em direção a uma nova exceção à imunidade estado pode expandir-se de modo a tornar-se, a longo prazo, uma prática geral apoiada por opinio juris e cristalizar uma nova norma de direito internacional consuetudinária. Tal cenário foi corroborado pela declaração de três Estados que ratificaram a Convenção, ao salientarem que este instrumento não acarreta nenhum prejuízo a qualquer desenvolvimento futuro do direito internacional sobre a proteção dos direitos humanos. ${ }^{254}$

251 UNITED NATIONA. A/C.6/54/L.12. U.N. Chairman of the Working Group, Convention on jurisdictional immunities of States and their property. 12 November 1999.

252 HAFNER, GERHARD. State Immunity and the New U.N. Convention. In: Chatham House Conference 5 October 2005.

${ }^{253}$ Report of the Working Group on Jurisdictional Immunities of States and Their Property, U.N. Doc. A/CN.4/SER.A/1999/Add.1 (Part 2).

254 Declaração apresentada pela Noruega. A Suécia e a Suíça também fizeram declarações semelhantes. UNITED NATIONS. Convention on Jurisdictional Immunities of States and Their Property: Declarations and Reservations. New York, 2 December 2004. 
Por ora, a prática do afastamento da imunidade do Estado em casos de violação de normas imperativas ou outras violações dos direitos humanos continua a ser escassa. Em 1996, os EUA aprovou uma emenda ao Foreign Sovereign Immunities Act (FSIA) que nega a imunidade de Estados patrocinadores do terrorismo em processos civis por crimes relacionados com o terrorismo. ${ }^{255}$ No entanto, fora do escopo dessa exceção, os tribunais norte-americanos, em sua maioria rejeitou as alegações de que um Estado estrangeiro deve perder sua imunidade devido à sua suposta violação de uma norma de direitos humanos (incluindo as de caráter jus cogens). ${ }^{256}$

Quanto a outras jurisdições, duas decisões proferidas por tribunais nacionais supremos que tratavam de violações do direito internacional humanitário durante a Segunda Guerra Mundial, são frequentemente citados como polares sustentadores da nova exceção à imunidade: os "direitos humanos".

Em 2000, o Supremo Tribunal grego, diante de uma ação civil por danos decorrentes de crimes cometidos contra a população civil de uma aldeia grega por uma unidade das forças armadas alemã rejeitou o pedido de imunidade da Alemanha sob alegação de que um Estado violador de normas de jus cogens não poderia invocar imunidade de jurisdição, pois teria tacitamente renunciado a ela, e garante também que atos do Estado que violem normas de jus cogens não possuem características de atos de soberania, não usufruindo, desta forma, do privilégio de imunidade. ${ }^{257}$ Destarte, mesmo que tais atos tenham sido praticados pelas forças armadas alemãs, eles não poderiam ser considerados como exercício de soberania estatal- e assim protegidos pela imunidade de jurisdição- posto que o fato de atentarem contra normas de jus cogens os descaracterizaria. Esta premissa - a que um Estado que infringe normas imperativas de direito internacional renuncia implicitamente à imunidade de jurisdição à qual ordinariamente faria jus - foi

255 Vide 28 USC $\S 1605 A$. UNITED STATES CODE. Terrorism exception to the jurisdictional immunity of a foreign state.

256 Vide SUPREME COURT OF THE UNITED STATES. Saudi Arabia et al v. Nelson et ux. United States of America, 1993. Cf. CASSESE, A. International law. 2 ${ }^{\mathrm{a}}$. ed. Oxford: Oxford University Press, 2005. p. 105 et seq.

257 BATENKAS, I. Prefecture of Voiotia v. Federal Republic of Germany. Case No. 137/1997. The American Journal of International Law, v. 92, n. 4, p. 767, 1998. 
inicialmente delineada como uma "proposta de interpretação evolutiva" 258 do artigo 1605 A do Foreign Sovereign Immunities Act de 1976. Os doutrinadores Belsky, Merva e Roth-Arrianza aventaram que:

A existência de um sistema de regras que os Estados não podem violar
significa que, quando um Estado age violando tal regra, o ato não é
reconhecido como soberano. Quando o ato de um Estado não é mais
reconhecido como soberano, o Estado não tem mais direito a invocar a
defesa da imunidade soberana. Portanto, ao reconhecer um grupo de
normas imperativas, os Estados estão implicitamente consentindo em
renunciar à imunidade quando eles violarem uma destas normas. ${ }^{259}$

Após quatro anos do caso Prefecture of Voiotia and others v. Federal Republic of Germany, também conhecido como "Caso do Massacre de Distomo", (supra elucidado), no caso Ferrini, o Tribunal de Cassação italiano negou o pedido de imunidade da Alemanha numa ação de indenização apresentada por um civil italiano que tentou sem sucesso obter indemnização nos tribunais alemães referente a sua deportação para um campo de trabalhos forçados na Alemanha. ${ }^{260}$

Entretanto, os tribunais do Canadá, Inglaterra e França têm defendido a imunidade em relação a processos cíveis de indemnização intentadas contra Estados estrangeiros por violações graves dos direitos humanos, mesmo quando as normas violadas tiverem o caráter jus cogens. ${ }^{261}$

Comporta, assim, estabelecer por derradeiro que, notoriamente, ainda, não há uma pratica consolidada entre os Estados de que a preceito da imunidade deve ser afastado quando o caso tratar sobre normas de jus cogens. Não obstante, uma nova

258 GAUDREAU, J. Immunité de l'État et violation des droits de la personne: Une approche jurisprudentielle. Paris: HEI Publications, 2005. p. 27.

259 BELSKYT, A. C.; MERVA, M.; ROHT-ARRIAZA, N. Implied Waiver Under the FSIA: A Proposed Exception to Immunity for Violations of Peremptory Norms of International Law. California Law Review, v. 77 , p. 394, 1989.

260 Esse caso será detalhadamente explanado no ponto 4.4 do presente trabalho.

261 COURT OF APPEAL OF ONTARIO. Bouzari v. Islamic Republic of Iran. Canada, 2004; COURT OF APPEAL (CIVIL DIVISION). Suleiman Al-Adsani v Government of Kuwait and Others. United Kingdom, 1994; HOUSE OF LORDS. Jones v. Ministry of Interior of the Kingdom of Saudi Arabia. United Kingdom, 2006; COUR DE CASSATION PREMIERE CHAMBRE CIVILE. Bucheron v. République Fédérale d'Allemagne. Paris, 2003. Cf. SHAW, M. N. International law. 5th. ed. Cambridge: Cambridge University Press, 2003. p. 638-640; DIXON, M. Textbook on international law. 5a. ed. Oxford: Oxford University Press, 2005. p. 173-174; FOX, H. The law of state immunity. Oxford: Oxford University Press, 2002. p. 117 et seq. 
tendência nessa direção está a emergir. De qualquer modo, não é sempre necessário que haja a disposição uma ampla aprovação antes que seja reconhecido que o jus cogens transcende o direito internacional consuetudinário contrário. Isto se aplica nomeadamente quando as normas peremptórias tem por escopo proteger os valores fundamentais da comunidade internacional que são considerados mais imperativos e primordiais do que as preocupações tradicionais do Estado resguardados pelas normas relativas as imunidades do Estado. ${ }^{262}$

Além disso, notavelmente, no caso de tortura e outros crimes internacionais (todos proibidos pelas normas jus cogens) a regra costumeira sobre a imunidade dos agentes do Estado prevê que tal privilégio não será concedido e que o agente do Estado, que cometer tais atos, será responsabilizado pessoalmente pela violação de uma norma internacional.

A questão que se descortina nessa esteira é a de que se a violação de uma norma imperativa implica que o autor individual não seja mais protegido pela norma consuetudinária da imunidade funcional (corolário da regra geral relativa à imunidade do Estado de qualquer ingerência externa na organização interna do Estado), por que na regra da imunidade de jurisdição do Estado o jus cogens não produz os mesmos ou semelhantes afeitos?

\subsection{A violação da imunidade como fato gerador de responsabilidade internacional}

Ao abrigo do sistema clássico a recusa ou a concessão da imunidade parece ter pouca relevância direta para a responsabilidade do Estado, mesmo que uma das justificativas da imunidade é de dar liberdade ao Estado para resolver reclamações feitas contra ele. O ilustre doutrinador lan Brownlie, sabiamente, sublinhou que "não

${ }^{262}$ CASSESE, A. International law. 2a ${ }^{\text {a }}$ ed. Oxford: Oxford University Press, 2005. p. 107-108. 
há imunidade de responsabilidade internacional onde está exista não termos do Direito Internacional geral”. 263

A questão a saber é, se a imunidade for concedida, o Estado demandado é obrigado a prover uma reparação alternativa? Tanto sob o abrigo do direito municipal quanto no direito internacional, parece que não. Parece que não, seja sob a lei municipal ou do direito internacional, é da essência desta causa que o tribunal municipal de outro Estado reconheça que não tem competência para determinar o tempo ou o modo que um Estado soberano estrangeiro deve dispor das reclamações apresentadas contra ele. A imunidade do estado não trata apenas a matéria da reclamação como não sujeita ao julgamento dos tribunais, mas também concede ao Estado demandado o arbítrio de dispor sobre a reivindicação. Consequentemente, embora a demonstração da existência de alguns métodos alternativos de resolução poderem influenciar o tribunal municipal em sua recusa para exercer jurisdição sobre o Estado estrangeiro, o mesmo não tem competência de tornar a sua decisão condicionada à aceitação do Estados de tal método alternativo. 264

Comporta, assim estabelecer que, onde a imunidade for recusada, o resultado da reclamação é determinado unicamente pelo direito municipal; qualquer decisão em favor de indivíduos não tem qualquer efeito no direito internacional, embora o reconhecimento mútuo das decisões judiciais entre o sistema legal da foro e a do estado demandado poder produzir efeitos no direito municipal do estado demandado. 265

Assim, a concessão ou recusa da imunidade parece não ter consequência direta para a responsabilidade do Estado demandado. Quando o reclamante for um nacional do Estado demandado, nos termos do direito clássico, em decorrência da aplicação do procedimento da exaustão das vias de recurso interno segundo a qual "uma reclamação não é admissível no plano internacional, a menos que o indivíduo

263 BROWNLIE, I. Princípios de direito internacional público. Lisboa: Fundação Calouste Gulbenkian, 1997. p. 348.

${ }^{264}$ FOX, H. The law of state immunity. Oxford: Oxford University Press, 2002. p. 522.

265 Ibidem, p. 522. 
ou a sociedade em causa tenha esgotado os recursos jurídicos à sua disposição no Estado que se alega ser o autor do dano", ${ }^{266}$ as reparações pleiteadas pelos demandantes encontram-se confinados aos disponíveis para ele no sistema nacional do Estado da sua nacionalidade. ${ }^{267}$

Contudo, a situação se complica quando um outro Estado, talvez o Estado do foro, tenha condições de estender a proteção diplomática ao autor da denúncia, ou se o requerente tem dupla nacionalidade. Duas situações são possíveis nesses casos. 268

Uma delas é tratar a imunidade como irrelevante para a questão da responsabilidade do Estado; se a imunidade for concedida o Estado do foro pode ainda defendem a argumentação de que o pedido do reclamante não foi atendida, e pode igualmente fazê-lo quando a imunidade for afastada, a menos que o Estado demandado fornecer, sob o direito municipal, a reparação que a responsabilidade do Estado requer; mas em ambos os casos, o pedido deve qualificar-se, independentemente da lei municipal, como uma violação do direito internacional. 269

A outra conjuntura é tratar a concessão da imunidade com matéria respeitante à acta jure imperii e, portanto, só pode ser dirimida por negociação direta entre os Estados, no plano internacional; por outro lado, se a imunidade for recusada, a reclamação é, desse modo, classificada como reclamação de direito municipal que não possui relevância para o direito internacional. 270

Repise-se por derradeiro que, "the plea is one of immunity from suit, not of exception from the law. This is shown clearly by the fact that immunity can be waved and then the case can be decided by the application of the law in the ordinary way". 271

\footnotetext{
266 BROWNLIE, I. Princípios de direito internacional público. Lisboa: Fundação Calouste Gulbenkian, 1997. p. 518.

267 FOX, H. The law of state immunity. Oxford: Oxford University Press, 2002. p. 522.

268 Ibidem, p. 522.

269 Ibidem, p. 522.

270 Ibidem, p. 523.

271 lbidem, p. 19-20.
} 


\subsection{Caso Ferrini: Imunidades de Jurisdição do Estado (Alemanha v. Itália; Grécia intervindo)}

O caso Ferrini é um caso emblemático do exercício jurisdicional da Comissão Internacional de Justiça, visto que a lide entre Itália e Alemanha pôs em risco a complexa análise do princípio da imunidade de jurisdição do Estado, perfilhado pelo direito internacional costumeiro.

$\mathrm{Na}$ demanda, os juízes da Corte se debruçaram sobre o questionamento quanto à possibilidade de um Estado ser competente para julgar, no domínio de sua própria jurisdição, outro Estado quando a querela versar sobre violações a princípios fundamentais possuidoras de alto valor ético e hierárquico, denominadas jus cogens. O caso aborda, portanto, a possibilidade de uma nova forma de relativização da imunidade de jurisdição do Estado.

\subsection{Aspectos fáticos}

É notório que a origem da disputa em tela é histórica. A vista disso, teceremos suscintamente os fatos históricos para melhor entendimento do caso.

No decorrer da Segunda Guerra Mundial, formaram-se dois grupos de combate: os Aliados, liderados pela Inglaterra e pelos Estados Unidos da América; e o Eixo, formado pela Alemanha, Itália e Japão. Contudo, esse senário viria a sofrer alterações com a mudança de posição da Itália, tanto política quanto na guerra, resultado da demissão de Mussolini em setembro de 1943, o então primeiro-ministro italiano e grande aliado de Hitler, e da rendição Italiana aos Aliados. Tal vicissitude 
levou a Itália a declarar guerra à Alemanha e, sintomaticamente, na invasão da Itália pelos exércitos alemães. ${ }^{272}$

Como a Itália havia sido aliada da Alemanha, grande parte do seu território estava ocupado pelas forças alemãs. Consequentemente, entre outubro de 1943 até maio de 1945 (período de ocupação), ocorreram inúmeras violações dos direitos humanos do povo italiano, perpetrados pelo exército alemão. Essas violações deram-se de diversos modos, incluindo massacres e a deportação de um grande número de civis. Isso nos permite categorizar as vítimas em três grupos. O primeiro, formado por homens jovens que foram deportados para Alemanha com o intuito de trabalharem em regime forçado. O segundo grupo, constituído por membros da força armada italiana, considerados prisioneiros de guerra, que igualmente ao primeiro grupo, realizaram trabalho forçado. O terceiro grupo compreende, em geral, as vítimas de massacres perpetrados pelas forças alemãs durante os últimos meses do conflito, que objetivavam controlar focos de resistência. ${ }^{273}$

Nesse diapasão impende destacar que, durante a ocupação alemã na Itália, inúmeras pessoas, civis e militares, foram retiradas forçosamente de seus lares e enviadas à Alemanha para trabalharem em indústrias alemãs sob regime similar à escravidão, em condições desumanas e com uma elevadíssima carga horaria, sem nenhuma liberdade. Ademais, como acima aludido, as forças alemãs realizaram inúmeros massacres com o intuito de eliminar qualquer tipo de resistência. ${ }^{274}$

Logo após o término da Segunda Guerra Mundial, em 10 de fevereiro de 1947,foi celebrado entre a Itália e as forças Aliadas o Tratado de Paz com a Itália. Inúmeras questões foram abordadas nesse Tratado, incluindo reparações de guerra, direitos de minorias e ajustes territoriais, isto é, as consequências legais e econômicas da Segunda Guerra Mundial. Citamos o artigo 77, no 4 do Tratado:

272 INTERNATIONAL COURT OF JUSTICE. Jurisdictional Immunities of the State (Germany v. Italy: Greece intervening). Judgment, I.C.J. Reports 2012, p. 99. № 21.

273 INTERNATIONAL COURT OF JUSTICE. Jurisdictional Immunities of the State (Germany v Italy). The Hague, Netherlands, 2008. p. 14.

274 INTERNATIONAL COURT OF JUSTICE. Jurisdictional Immunities of the State (Germany v. Italy: Greece intervening). Judgment, I.C.J. Reports 2012, p. 99. № 21, p. 13. 
Sem prejuízo a este e outros dispositivos, em favor da Itália de seus cidadãos e dos Poderes ocupando a Alemanha, a Itália renuncia em seu favor e dos de todos seus cidadão todas as reclamações contra a Alemanha e cidadãos alemães que estejam em vigor em 8 de Maio de 1945, exceto aquelas que surgiram em contratos e outras obrigações em vigor e Direitos adquiridos antes de primeiro de Setembro de 1939. Esta renúncia deve incluir débitos e todas as reclamações intergovernamentais a respeito de acordos celebrados no curso da guerra e todas as reclamações por perdas ou danos que surjam durante a guerra. ${ }^{275}$

A corroborar o exposto, de acordo com tal dispositivo, o Estado italiano estaria abdicando futuras reclamações contra a Alemanha.

Em 1953 a República Federativa da Alemanha adotou a Lei Federal de Compensação para indenizar certos grupos de vitimas de perseguição nazista (Bundesentschädigungsgesetz (BEG)). Inúmeros pedidos de ressarcimento efetuados por civis italianos foram negados, sob a alegação de que alguns reclamantes não se classificam como vitimas de acordo com a definição estabelecida pela Lei de Compensação, ou por não terem residência permanente na Alemanha, como requerido pela determinada lei. ${ }^{276}$

A lei supramencionada foi emenda em 1965 com o objetivo de abarcar casos de pessoas perseguidas por sua nacionalidade ou sua relação com grupos não germânicos. Contudo exigia-se que estas pessoas tivessem status de refugiado em 1 de outubro de 1953. Mesmo após a emenda, muitos italianos ainda não se qualificavam para a compensação por não terem o status de fugitivos. Em virtude da especificidade da Lei Federal de Compensação, tanto em sua forma original quanto seguida da emenda, as ações de vitimas de outras nacionalidades foram, em geral, rejeitadas pelas cortes alemãs.

Após o Tratado de Paz com a Itália, a Alemanha tomou várias outras medidas para compensar os que sofreram durante o período nacional-socialista, dois dos

\footnotetext{
275 op. cit., no 22, 4 .

276 op. cit., no 23.
} 
quais eram específicos para a Itália e os seus nacionais. O primeiro, que entrou em vigor em 16 de setembro de 1963, dizia respeito ao acerto de algumas questões relacionadas à propriedade, economias e finanças. O segundo acordo, que entrou em vigor em 31 de julho de 1963, tratava da compensação a nacionais italianos que sofreram medidas de perseguição do nacional-socialismo alemão. Em virtude desse acordo, a República alemã aceitou compensar os nacionais italianos afetados por estes termos. ${ }^{277}$

No entanto, apesar dessas medidas, um grande número de ex-militares italianos foram incapazes de exigir qualquer indemnização e reivindicações em tribunais alemães e suas ações no Tribunal Europeu dos Direitos do Homem foram infrutíferas. ${ }^{278}$

Essa conjuntura viria a mudar a partir de 23 de setembro de 1998, quando o Sr. Luigi Ferrini, cidadão italiano que foi deportado para Alemanha, durante o período de invasão, para realizar trabalho forçado na indústria de armamentos daquele país, entrou com um processo contra a República da Alemanha na corte de Arezzo (Tribulnale di Arezzo). Após ter o provimento de seu caso negado por duas vezes sob alegação de falta de jurisdição sobre o caso, exatamente por estar pedindo indenização contra um Estado soberano, finalmente o Sr. Ferrini alcançou algum resultado. 279

Em 11 de março de 2004, a Suprema Corte Italiana de Cassação (Corte di Cassazione) declarou possuir a jurisdição necessária para julgar o Estado alemão, afirmando que a imunidade não se aplica a circunstâncias em que o motivo da reclamação constitua um crime internacional; a partir de então, as portas foram abertas para que mais italianos buscassem na justiça reparos por parte do governo alemão. ${ }^{280}$ Desde 2004, mais de 250 pessoas impetraram ações civis contra a Alemanha, as quais se encontram pendentes em 24 cortes regionais e duas cortes

\footnotetext{
277 op. cit., no 24 - 25 .

278 op. cit., no -26.

279 op. cit., ํㅡ 27.

280 op. cit., $n^{\circ}=28-29$.
} 
de apelação. ${ }^{281}$ A Alemanha teve ainda bens confiscados, como é o caso da Villa Vigoni, centro germano-italiano de intercâmbio cultural, que se encontra sob hipoteca judiciária em vista dos processos em andamento.

No entanto, o Tribunal de Cassação italiano não foi único a determinar que as ações judiciais provenientes das atrocidades perpetradas pelas forças armadas alemãs durante a Segunda Guerra Mundial eram justiçáveis. Mesmo antes da decisão Ferrini, o Tribunal de Cassação grego já havia mantido as decisões dos tribunais inferiores, que concediam indenizações a indivíduos que haviam impetrado ações contra a Alemanha com o intuito de reparar os danos causados pelos alemães no massacre civil ocorrido na cidade grega de Distomo. ${ }^{282}$ Apesar da decisão favorável, os demandantes não foram capazes de executar a sentença na Grécia, posição esta que manteve-se inalterada mesmo após a conclusão do processo no Tribunal Europeu dos Direitos do Homem (ECtHR).

\subsection{O caso no Tribunal Internacional de Justiça}

Com o aumento exponencial do número de ações contra seu Estado, a Alemanha viu-se obrigada a tomar uma medida, e resolveu, em 23 de dezembro de 2008, recorrer ao Tribunal Internacional de Justiça (ICJ) com o intuito de assegurar o seu direito de imunidade ante as cortes italianas, alegando que a Itália estaria ferindo a sua imunidade de jurisdição ao julgar o Estado Alemão em suas cortes civis por violações aos Direitos Humanos ocorridos durante a Segunda Guerra Mundial. ${ }^{283}$

281 INTERNATIONAL COURT OF JUSTICE. Jurisdictional Immunities of the State (Germany $\mathbf{v}$ Italy). The Hague, Netherlands, 2008.

282 HELLENIC SUPREME COURT OF CIVIL AND PENAL LAW. Prefecture of Voiotia v. Federal Republic of Germany. Greece, 2007. International Law Reports, V. 129, p. 514 et seq.

283 INTERNATIONAL COURT OF JUSTICE. Jurisdictional Immunities of the State (Germany v Italy). The Hague, Netherlands, 2008. p. 4. 


\subsubsection{Questão jurídica: Normas jus cogens v. imunidade de jurisdição}

A jurisprudência dos tribunais italianos trouxe a baila uma questão crucial perante o TIJ, nomeadamente o conflito entre as normas jus cogens e a imunidade de jurisdição do Estado. ${ }^{284}$

A principal questão trazida perante o Tribunal é a de que se um Estado não realizar de forma satisfatória o dever de reparar violações de direitos humanos que, alegadamente, é suscetível de produzir efeitos jurídicos, pode ter a sua imunidade de jurisdição afastada por tribunais estrangeiros. ${ }^{285}$ Em outras palavras, o ponto centra da disputa é se o princípio da imunidade Estado poderia, e deveria, operar para impedir um Estado de ser processado em um tribunal de um Estado estrangeiro em caso atinente à supostas violações de normas jus cogens.

Assim, a questão é se nos casos envolvendo compensação oriunda de crimes contra a humanidade as Cortes Italianas possuem ou não o condão de afastar a imunidade de jurisdição do Estado Alemão.

\subsubsection{A posição alemã}

A petição de reclamação da Alemanha contra a Itália está alicerçada em uma série de medidas perpetradas pelo governo italiano concernentes à quebra de imunidade jurisdicional do Estado Alemão. Conforme a petição, o governo italiano

\footnotetext{
${ }^{284}$ MONETA, FRANCESCO. State Immunity for International Crimes: The Case of Germany versus Italy before the ICJ: Jurisdictional Immunities of the State (Germany v. Italy). The Hague Justice Portal, 2009.

285 INTERNATIONAL COURT OF JUSTICE. Jurisdictional Immunities of the State (Germany v. Italy: Greece intervening). Judgment, I.C.J. Reports 2012, p. 99. p. 21.
} 
teria infringido princípios fundamentais de direito internacional público ao julgar o estado Alemão em suas cortes. ${ }^{286}$

De acordo com o Estado Alemão o governo italiano feriu princípios fundamentais de direito internacional público que fomentam a convivência pacífica entre as nações, ao julgar a República Alemã em seus tribunais.

Ademais, o governo alemão alega que a Itália despeitou duplamente a sua imunidade de jurisdição, ao aplicar medidas restritivas em um território da propriedade alemã, Villa Vigoni, utilizado para fins comerciais e de intercâmbio cultural entre os dois países. ${ }^{287}$

Ante a decisão do tribunal italiano, respeitante à quebra de imunidade de jurisdição da Alemanha, o governo alemão apresentou como contraponto a suposta renúncia do governo italiano aos direitos de indenização seus e dos seus cidadãos, apresentado no artigo 77 (4) do Tratado de Paz de 1947:

Sem prejuízo a este e outros dispositivos, em favor da Itália de seus bens e
seus bens e dos Poderes ocupando a Alemanha, a Itália renuncia em seu
favor e dos de todos seus cidadãos todas as reclamações contra a
Alemanha e cidadãos alemães que estejam em vigor em 8 de maio de
1945, exceto aquelas que surgiram em contratos e outras obrigações em
vigor de Direitos adquiridos entes de primeiro de setembro de 1939. Esta
renúncia deve incluir débitos e todas as reclamações intergovernamentais a
respeito de acordos celebrados no curso da guerra e todas as reclamações
por perdas e danos que surjam durante a guerra. ${ }^{288}$

De acordo com o entendimento do governo alemão, através de mecanismos expressos no Tratado de Paz, obteve o perdão de todas as dívida decorrentes da guerra, além de eximir-se das violações dos direitos humanos dos cidadãos italianos, que poderiam ser cobrados da Alemanha. ${ }^{289}$

Concernente a uma outra questão aventada pela jurisprudência italiana, sobre o tratado celebrado bilateralmente entre a Itália e a Alemanha, em 1961, que

286 INTERNATIONAL COURT OF JUSTICE. Jurisdictional Immunities of the State (Germany v Italy). The Hague, Netherlands, 2008.

287 Ibidem.

288 UNITED NATIONS. Treaty of Peace with Italy. Paris, 1947.

289 INTERNATIONAL COURT OF JUSTICE. Jurisdictional Immunities of the State (Germany v. Italy: Greece intervening). Judgment, I.C.J. Reports 2012, p. 99. 
comprova a existência de uma falta de indenização reiterada a certos grupos de cidadãos italianos e consequentemente a criação em 2000 da instituição Lembrança, Responsabilidade e Futuro, ${ }^{290}$ a Alemanha assevera que a situação de indenização foi inteiramente resolvida pelo Tratado de Paz de 1947. ${ }^{291}$

Assim sendo, em consonância com a defesa alemã, ambos os Tratados celebrados em 1961 e a criação da instituição Lembrança, Responsabilidade e Futuro constituem atos de boa vontade do governo Alemão destinados a findar as disputas legais respeitantes à compensação nos casos individuais, por conseguinte, não possuem valor jurídico para comprovar a nova situação, como sustentada pela jurisprudência italiana.

Ora, a Alemanha alega que a sua imunidade jurisdicional não pode ser afastada, haja vista que, o ato por ele praticado constitui um acta jure imperii. 292

\subsubsection{A defesa da Itália}

A governo Italiano apresentou, em 22 de dezembro de 2009, seu pedido de reconvenção perante o Tribunal Internacional de Justiça ante o pedido original da Alemanha. O escopo do pedido pedir ao Tribunal para asseverar que a Alemanha tem violado suas obrigações em prover reparação efetiva de vítimas italianas de crimes nazistas e que a Alemanha pare com sua conduta errada e assuma sua responsabilidade internacional por tal conduta:

Italy invites the Court to find that no dispute thus exists between the Parties as regards Germany's responsibility for the indisputably criminal acts committed by the Third Reich against Italians to which the Italian case law denying jurisdictional immunity to the German State refers. In other words, the existence of the obligation to make reparation for the crimes committed, its non-derogable nature and its permanence in relation to today's

290 BUNDESGESETZBLATT. Statutes For The Foundation "Remembrance, Responsibility and the Future". 2 August 2000.

291 INTERNATIONAL COURT OF JUSTICE. Jurisdictional Immunities of the State (Germany v. Italy: Greece intervening). Judgment, I.C.J. Reports 2012, p. 99.

292 Ibidem. № 61 
democratic Germany can and must be analysed and ascertained by the international judge on the basis of these certain and incontrovertible data. ${ }^{293}$

A alegação apresentada pela Itália aponta que a Alemanha não teria tomado as providencias necessárias para reparar os danos sofridos pelos cidadãos italianos. Ademais, a defesa italiana requereu uma análise não dos fatos sucedidos na Segunda Guerra Mundial, pois nenhuma nação os nega, mas sim dos acordos firmados entre a Alemanha e a Itália em 1961, assim como a criação da instituição Lembrança, Responsabilidade e Futuro, em 2000. Em consonância com o entendimento alemão, os eventos que se deram na ocupação alemã teriam suscitado os direitos dos cidadãos italianos à indenização que desde então não teria sido efetuado pelo governo alemão. 294

Ora, a Itália também defende a existência de uma ligação entre a questão do cumprimento da obrigação da Alemanha de reparar às vítimas e a da imunidade jurisdicional que a Alemanha dispõe nos órgãos jurisdicionais estrangeiros que se aplicam a essas vítimas, na medida em que um Estado incumprir a sua obrigação de indenizar as vítimas de graves violações do direito internacional humanitário, deixando essas vítimas sem meios eficazes de reivindicar a reparação a qual possam ter direito, o Estado ficaria privado do direito de invocar a sua imunidade jurisdicional perante os tribunais do Estado da nacionalidade das vítimas. ${ }^{295}$

Nesse diapasão, é imperioso enaltecer que, a Itália, nas suas alegações perante o Tribunal, sustenta que a Alemanha não tem direito a imunidade em relação aos casos perante os tribunais italianos, por duas razões: primeiro, que a imunidade referente ao acta jure imperii não se estende aos atos ilícitos ou delitos que ocasionarem morte, danos pessoais ou danos materiais cometidos no território do Estado do foro; em segundo lugar, que, independentemente do local onde os atos relevantes ocorreram, a Alemanha não goza de imunidade porque esses atos

\footnotetext{
293 INTERNATIONAL COURT OF JUSTICE. Case concerning Jurisdictional Immunities of the State (Germany v. Italy) counter-memorial of Italy. 22 December 2009. Sec. IV, 1.13.

294 INTERNATIONAL COURT OF JUSTICE. Jurisdictional Immunities of the State (Germany v. Italy: Greece intervening). Judgment, I.C.J. Reports 2012, p. 99.

295 Ibidem, no 45.
} 
envolveram as mais graves violações de regras de direito internacional de caráter peremptório, às quais nenhuma derrogação é possível. 296

Mencione-se que, em segundo argumento a Itália, que, ao contrário de seu primeiro argumento, se aplica a todas as reivindicações perante os tribunais italianos, assevera que a negação da imunidade se justifica em consideração a natureza especial dos atos que constituem o objeto das reivindicações perante os tribunais italianos e as circunstâncias em que foram efetuadas essas reivindicações. São três os fundamentos para este argumento. Em primeiro lugar, a Itália alega que os atos que originaram às reivindicações constituem graves violações de princípios do direito internacional, aplicáveis à realização de um conflito armado, crimes de guerra e crimes contra a humanidade. Em segundo lugar, a Itália afirma que as regras do direito internacional violadas pela República Alemã eram normas imperativas (jus cogens), inderrogáveis pela vontade das partes. Em terceiro lugar, a Itália argumenta que os requerentes tiveram negados todos os seus pedidos de reparação, tornando o exercício da jurisdição pelos tribunais italianos necessário como último recurso. ${ }^{297}$

Por derradeiro, a Itália sustentou que os seus tribunais tinham o direito de negar a imunidade do Estado, devido ao efeito desses três fundamentos combinados. ${ }^{298}$

\subsubsection{A intervenção da Grécia}

Em janeiro de 2011, a Grécia solicitou sua participação no caso com base no art. 62 do Estatuto da Corte, sob o argumento de que a Alemanha havia consentido

\footnotetext{
296 INTERNATIONAL COURT OF JUSTICE. Jurisdictional Immunities of the State (Germany v. Italy: Greece intervening). Judgment, I.C.J. Reports 2012, p. 99. nos. 61, 62,80 e 81. 297 Ibidem, no 61. 298 Ibidem, no 61.
} 
quanto à sua responsabilidade internacional sobre todos os atos cometidos pelo Terceiro Reich quando de sua invasão ao território grego. ${ }^{299}$

No pedido apresentado à Corte, a Grécia alega que unicamente tem a intenção de intervir nos aspectos procedimentais atinentes aos julgamentos realizados em seu território, corroborado pela jurisprudência italiana, concernentes aos acontecimentos ocorridos durante a Segunda Guerra Mundial. Em consonância com a República Helênica, nenhuma das partes do caso levou em consideração as implicações deste para Estados terceiros, advogando o princípio de segurança jurídica. ${ }^{300}$

A Corte em seu regulamento, especificamente no artigo 81, define a obrigação de um Estado, que tem a pretensão de intervir em um caso, justificar tal intenção: (a) em termos de um interesse jurídico próprio que seja afetado pela decisão do caso, (b) da apresentação do objeto preciso de intervenção e (c) da jurisdição entre o Estado que intenciona intervir e as partes. ${ }^{301} \mathrm{O}$ interesse jurídico, alegado pela Grécia para intervir no caso, deriva do fato de que a Alemanha ter consentido sobre sua responsabilidade internacional vis-à-vis a Grécia por todos os atos e omissões perpetrados pelo Terceiro Reich entre o período de abril de 1941 e maio de $1945 .{ }^{302}$

Posteriormente, a República Helênica elucida dois fitos da sua intervenção: resguardar e preservar o direitos da Grécia de acordo com todos os meios disponíveis, especialmente no que tange aos princípios de jurisdição e a instituição de responsabilidade do Estado, e informar o Tribunal a natureza dos direitos e interesses gregos que podem ser afetados pela decisão do Tribunal. ${ }^{303}$

No que tange à jurisdição da Corte, a Grécia não deseja nem procura tornarse parte do caso pendente no Tribunal. Por conseguinte, o seu pedido de

\footnotetext{
299 INTERNATIONAL COURT OF JUSTICE. Application for Permission to Intervene by the Government of the Hellenic Republic. General List № 143, 13 January 2011. p. 4.

300 Ibidem. p. 6.

301 INTERNATIONAL COURT OF JUSTICE. Rules of court. 1978.

302 INTERNATIONAL COURT OF JUSTICE. Application for Permission to Intervene by the Government of the Hellenic Republic. General List № 143, 13 January 2011. p. 6-7.

303 Ibidem, p. 10.
} 
intervenção baseia-se exclusivamente e exaustivamente sobre o artigo 62 do Estatuto da Corte. ${ }^{304}$

O Tribunal Internacional de Justiça, em julho de 2011, julgou o pedido de intervenção da República Helênica no caso como procedente. O mesmo levou em consideração o fato de a Suprema Corte Helênica (Areios Pagos) ter confirmado o julgamento contra a Alemanha realizado pelo Tribunal da Primeira Instância (Protodikeio) de Livadia, no caso Distomo, contudo o Ministro da Justiça recusou tal julgamento, respeitando o artigo 93 do Código Civil grego, atinente ao julgamento de um Estado estrangeiro. ${ }^{305}$

Ainda sobre o Caso Distomo, o Tribunal de Apelação de Florença, na Itália, declarou que tal julgamento poderia ser executado neste país, confirmando a decisão de um tribunal inferior italiano de que a decisão do Tribunal de Cassação grego era exequível em Itália. A partir de então, cidadãos gregos passaram a processar o Estado alemão a partir de tribunais italianos. ${ }^{306}$

O Tribunal Internacional de Justiça também levou em consideração o caso grego Margellos, julgado pelo Tribunal de Apelação de Atenas, no qual respeitou-se a imunidade da República alemã. ${ }^{307}$

Nos seguintes procedimentos escritos referentes à intervenção grega, a Alemanha assumiu opinião contrária à intervenção, asseverando que os interesses envolvidos no caso não eram respeitantes aos interesses gregos. Segundo a Alemanha, a responsabilidade do Estado Alemão pelas violações de direito internacional humanitário não era o cerne da disputa, a qual está centrada especificamente no princípio da imunidade de jurisdição. Ao passo que, a Itália, por

304 INTERNATIONAL COURT OF JUSTICE. Application for Permission to Intervene by the Government of the Hellenic Republic. General List № 143, 13 January 2011. p. 10,

305 Ibidem, p. 7.

306 Ibidem, p. 7-9.

307 Ibidem, p. 8-9. 
sua vez, manifestou-se de forma favorável, corroborando os interesses gregos afetados pelo futuro julgamento do Tribunal. 308

Repise-se, por derradeiro que, o TIJ deliberou a favor da intervenção grega declarando que a similaridade dos interesses da República Helênica aos casos italianos abrangidos no caso, precipuamente no que tange ao caso Distomo, deixando diáfano que a decisão proferida futuramente não terá caráter vinculante para a Grécia. 309

\subsection{Decisão e seus fundamentos}

A Corte Internacional de Justiça, em 03 de fevereiro de 2012, decidiu favoravelmente à Alemanha. A decisão tomada pela Corte sopesou minuciosamente a questão do princípio da imunidade, buscando elucidar o direito internacional no tema e dirimir os possíveis conflitos futuros atinentes à matéria. A Corte, primeiramente, esclareceu que o litígio refere-se exclusivamente à eventual violação, pela Itália, das imunidades de jurisdição e de execução da Alemanha, e não tem como escopo julgar as ações praticadas pelas forças nazistas, cuja ilegalidade sequer era contestada pelas Partes.

Cumpre trazer à baila que, ao longo do texto do julgamento, os juízes majoritários buscaram afastar as regras substantivas (atinentes às graves violações de direitos humanos durante a Segunda Guerra Mundial) daquelas processuais (concernentes às imunidades), e sublinhar que os crimes praticados naquele período "somente poderiam ser descritos como um completo desrespeito às considerações fundamentais de humanidade". ${ }^{310}$

308 INTERNATIONAL COURT OF JUSTICE. Application for Permission to Intervene by the Government of the Hellenic Republic. General List № 143, 13 January 2011. p. 10-11

309 Ibidem, p. 11-13.

310 INTERNATIONAL COURT OF JUSTICE. Jurisdictional Immunities of the State (Germany v. Italy: Greece intervening). Judgment, I.C.J. Reports 2012, p. 99. no 52. 
Nesse diapasão, a Corte assevera que resta diáfano que os assassinatos em massa, as deportações para trabalho escravo e os trabalhos forçados cometidos pelo Reich alemão já constituíam violações graves do jus in bellum (direito internacional aplicável a conflitos armados) no período entre 1943 e 1945, quando foram perpetrados. ${ }^{311}$

No que tange à imunidade, tanto Itália quanto Alemanha aquiesciam que não se trata simplesmente de cortesia entre Estados, mas sim de matéria regida pelo direito internacional. Uma vez que nenhuma das Partes havia assinado a Convenção das Nações Unidas sobre Imunidade de Jurisdição dos Estados Estrangeiros e seus Bens de $2004^{312}$ (a qual, de qualquer forma, ainda não encontra-se em vigor), o TIJ passou a considerar as normas costumeiras atinentes ao tema. Para tal, como de praxe, perquiriu a prática dos Estados e a opinio juris em relação aos preceitos de imunidade. Salientou, ademais, que já em 1980 a Comissão de Direito Internacional (CDI) da ONU assentara que o princípio da imunidade jurisdicional dos Estados era adotada como regra geral de direito consuetudinário. ${ }^{313}$

Embora as Partes não objetarem a relevância da imunidade dos Estados no direito costumeiro, a dissonância se apresentava quanto a finalidade e extensão de tal preceito. A Corte recordou a já corrente diferenciação entre atos soberanos (acta juri imperii) e atos de gestão (acta juri gestionis), presente na ora predominante teoria da imunidade jurisdicional relativa dos Estados. Os atos das forças armadas e órgãos alemães que motivaram os processos na Itália seriam, segundo a TIJ, atos soberanos, e, como tal, estariam acautelados pelas regras de imunidade de jurisdição do Estado. ${ }^{314}$

O Tribunal não acolheu o argumento italiano de que a imunidade por atos soberanos não se estenderia a ações judiciais de responsabilidade civil relativas a danos pessoais, morte ou danos à propriedade ocorridos no território do país que busca exercer jurisdição sobre o Estado estrangeiro. Tal cenário, previsto no artigo

311 INTERNATIONAL COURT OF JUSTICE. Jurisdictional Immunities of the State (Germany v. Italy: Greece intervening). Judgment, I.C.J. Reports 2012, p. 99. o 52.

312 Vide. subtítulo 3.3 do presente trabalho

313 INTERNATIONAL COURT OF JUSTICE. op. cit., nos 55-57.

314 Ibidem. no 60. 
12 da Convenção da ONU de 2004, não seria aplicável, conforme afiançou o Tribunal, a atos perpetrados pelas forças armadas de determinado Estado no andamento de um conflito armado. Assim, sem estabelecer detalhadamente seus critérios, o TIJ passou a elencar precedentes de tribunais domésticos com o fito de evidenciar que o direito internacional consuetudinário continua a prever a imunidade do Estado em processos judiciais relativos a danos causados por forças armadas ou outros órgãos do Estado no curso de um conflito armado. ${ }^{315}$

Igualmente, foi a afastado o segundo argumento da Itália, de que a gravidade das ações perpetradas impediria a aplicação das normas de imunidade de jurisdição. De acordo com o Tribunal, o direito internacional costumeiro não se desenvolveu a ponto de afastar a imunidade do Estado, mesmo em caso de graves violações de direitos humanos e do jus in bellum. O Tribunal elucidou, ademais, que suas conclusões neste ponto não afetam eventual discussão sobre a imunidade de Chefes de Estado em processos penais. ${ }^{316}$

O Tribunal não afirma manifestamente que os atos praticados pelas forças armadas alemã, mencionadas no caso em tela, teriam violado normas de jus cogens (que são inderrogáveis), contudo, parece apontar para esse entendimento. Assevera, entretanto, que inexiste conflito entre o jus cogens (direito substantivo) e a imunidade (direito procedimental), motivo pela qual a violação de normas peremptórias não acarretaria no afastamento da imunidade do Estado. Quer isso dizer que, a imunidade não estipula a legalidade do ato, isso porque a mesma é meramente procedimental, regulando unicamente o exercício da jurisdição. ${ }^{317}$

Ora, o Tribunal acrescenta que inexiste uma regra no direito internacional que exige o pagamento de uma indenização integral para cada vítima individual de crimes de guerra, como norma acolhida pela comunidade internacional em seu todo, como aquela em que nenhuma derrogação é permitida; inviabilizando a tese italiana de que o direito à reparação se sobrepunha à imunidade do Estado. Assim, os

315 INTERNATIONAL COURT OF JUSTICE. Jurisdictional Immunities of the State (Germany v. Italy: Greece intervening). Judgment, I.C.J. Reports 2012, p. 99. no 64.

316 Ibidem, ํㅡ 91.

317 Ibidem, nos 58, 93, 94. 
magistrados concluem, que mesmo sob a presunção de que as ações julgadas pelos tribunais italianos tivessem envolvido violações de jus cogens, a aplicação da norma costumeira da imunidade de jurisdição do Estado não seria afetada. ${ }^{318}$

A decisão do tribunal reconhece que, no caso de alguns italianos, não haveria outro meio de obter reparação pelas violações de direitos humanos sofridas durante a Segunda Guerra Mundial. O Tribunal ressalta, porém, que a responsabilidade do Estado pelo descumprimento do direito internacional - e sintomaticamente o dever de reparar - é questão distinta daquela atinente às imunidades. Uma vez que a própria TIJ negou a reconvenção italiana, ${ }^{319}$ cujo objeto consistia em requerimento à Alemanha de reparação por tais violações, evidencia a inexistência de remédios jurídicos alternativos para que as referidas vítimas obtenham algum tipo de reparação. A Tribunal recomenda, neste ponto, que os pedidos concernentes ao tratamento de nacionais italianos pelas forças nazistas entre 1943-1945 sejam tratados em negociações futuras entre Alemanha e Itália. ${ }^{320}$

\subsection{Declarações de voto e votos de vencido}

Com base nas conclusões supracitadas, o Tribunal Internacional de Justiça decidiu, por 12 votos a 3 (dissidentes os juízes Cançado Trindade - Brasil, Abdulqawi Yusuf - Somália, e ad hoc Giorgio Gaja - Itália), que a Itália violou sua obrigação de respeitar a imunidade do Estado alemão ao permitir o julgamento de ações cíveis fundamentadas atinentes à violações do direito internacional humanitário perpetradas pelas forças armadas alemã entre 1943 e 1945. Tendo prevalecido a imunidade do Estado neste que era o ponto mais controverso, as demais decisões da Corte Internacional de Justiça - referentes à imunidade de

318 INTERNATIONAL COURT OF JUSTICE. Jurisdictional Immunities of the State (Germany v. Italy: Greece intervening). Judgment, I.C.J. Reports 2012. p. 99. nos 94-97.

319 UNITED NATIONS. Summaries of Judgments, Advisory Opinions and Orders of the International Court of Justice. 2008 - 2012. Immunities of the State (Germany v. Italy). Counterclaim. Order of 6 July 2010.

320 INTERNATIONAL COURT OF JUSTICE. op.cit., nº 104. 
execução e à homologação de sentença estrangeira - foram adotadas por 14 votos a 1 (dissidente o juiz Cançado Trindade).

O Tribunal Internacional de Justiça determinou, como consequência da violação do direito internacional, que a Itália deverá adotar legislação (ou outras medidas que julgar cabíveis) com objetivo de descontinuar os efeitos das decisões judiciais que violaram a imunidade jurisdicional da Alemanha. A decisão não incluiu unicamente os julgamentos de mérito, mas designa-se, precipuamente, às medidas de constrição adotadas pela Itália contra propriedades alemãs situadas em território italiano, as quais deverão deixar de produzir efeito.

O magistrado Antônio Cançado Trindade, em seu voto dissidente, reprovou a decisão e os argumentos perfilhados pelo Tribunal Internacional de Justiça no litígio ora apresentado. De acordo o mesmo, a imunidade dos Estados não poderia ser analisada no vácuo, mas sim em conexão com os fatos que originaram o processo no qual esta é invocada. Em consequência, haveria na prática um conflito entre o direito humano de acesso à justiça (que deveria prevalecer, sobretudo face a crimes internacionais) e a norma consuetudinária de imunidade do Estado. Para o juiz brasileiro, graves violações de direitos humanos e do direito humanitário afastariam eventuais obstáculos à jurisdição impostos pelas regras de imunidade quando atinentes à pedidos de reparação pelas vítimas de tais atrocidades. ${ }^{321}$

Nesse diapasão, o magistrado brasileiro resgata a concepção de "crime de Estado", elucidada em versões mais antigas dos Artigos da Comissão de Direito Internacional (CDI) sobre responsabilidade do Estado, e que reforçou alguns de seus votos quando membro da Corte Interamericana de Direitos Humanos. ${ }^{322}$ Cançado Trindade vislumbra o afastamento da imunidade jurisdicional do Estado em casos atinentes à relações comerciais ou de acidentes automobilísticos e a sua manutenção face a graves violações de direitos humanos e de direito humanitário

321 Cf. INTERNATIONAL COURT OF JUSTICE. Jurisdictional Immunities of the State (Germany v. Italy: Greece intervening). Dissenting opinion of Judge Cançado Trindade. Judgment of 3 February 2012.

322 Vide, e.g., CORTE INTERAMERICANA DE DERECHOS HUMANOS. Caso Goiburú y otros Vs. Paraguay. Sentencia de 22 de septiembre de 2006 (Fondo, Reparaciones y Costas) 
como um "absurdo jurídico" (incongruência). ${ }^{323}$ Destarte, crimes internacionais perpetrados por entes estatais não constituiriam atos soberanos ou de gestão, mas sim "delicta imperii", para os quais a imunidade não poderia ser concedida. ${ }^{324}$

Em consonância à votos proferidos pelo juiz anteriormente - tanto na Corte Internacional de Justiça quanto na Corte Interamericana de Direitos Humanos -, e na mesma esteira de pensamento que sua doutrina, A. A. Cançado Trindade sublinha que "o direito, em todos os seus ramos, não opera no vácuo. Os instrumentos jurídicos, tanto nacionais como internacionais, porquanto encerram valores, são produto do seu tempo. E se interpretam e se aplicam no tempo. Encontram-se, pois, em constante evolução" ${ }^{325}$. Ora, propõe a humanização do direito internacional. ${ }^{326}$

Nesse sentido, o mesmo sublinha o papel do indivíduo como sujeito do direito internacional, titular, por conseguinte, de direitos e obrigações nesse âmbito. A partir desta premissa, assevera que a imunidade jurisdicional do Estado não constitui conceito estático, devendo reajustar-se ao direito das gentes contemporâneo. Afirma, nesse contexto, que: "there is no reason for keeping on overworking the rights of States while at the same time overlooking the rights of individuals. One and the other are meant to develop pari passu in our days, attentive to superior common values. State immunity and the fundamental rights of the human person are not to exclude each other, as that would make immunity unacceptably tantamount to impunity. ${ }^{327}$

Para concluir, o magistrado assevera que:

Jus cogens stands above the prerogative or privilege of State immunity, with all the consequences that ensue therefrom, thus avoiding denial of justice

323 Cf. INTERNATIONAL COURT OF JUSTICE. Jurisdictional Immunities of the State (Germany v. Italy: Greece intervening). Dissenting opinion of Judge Cançado Trindade. Judgment of 3 February 2012. ํㅡ 312.

324 Ibidem. nos 184 et seq.

325 TRINDADE, A. A. C. 0 direito internacional em um mundo em transformação: ensaios, 19762001. Rio de Janeiro; São Paulo: Renovar, 2002. p. 4-5.

326 TRINDADE, A. A. C. A humanização do direito internacional. Belo Horizonte: Del Rey, 2006.

327 INTERNATIONAL COURT OF JUSTICE. Application for Permission to Intervene by the Government of the Hellenic Republic. General List № 143, 13 January 2011. o 15; Cf. TRINDADE, A. A. C. The Access of Individuals to International Justice. New York: Oxford University Press, 2011. 
and impunity. On the basis of all the aforesaid, my firm position is that there is no State immunity for international crimes, for grave violations of human rights and of international humanitarian law. In my understanding, this is what the International Court of Justice should have decided in the present Judgment. ${ }^{328}$

A decisão dissidente do juiz Cançado Trindade representa uma evolução não unicamente na doutrina da imunidade do Estado, mas do direito internacional em si, uma vez que coloca os direitos humanos em primeiro lugar no direito internacional, pregando a construção de um novo jus gentium, o direito universal da humanidade.

\subsection{Análise: o posicionamento doutrinal sobre a imunidade do Estado v. jus cogens}

\subsubsection{Argumentos Soberanistas}

Segundo os defensores da aplicação do jus cogens no campo da imunidade, (denúncias de) violações de jus cogens deve acarretar na indisponibilidade da imunidade soberana, como defesa de um Estado-réu. Assim, por exemplo, não deve ser permitido que um Estado se "esconda" por trás de sua imunidade soberana em casos envolvendo denúncias de violações graves dos direitos humanos.

A fundamentação teórica desta doutrina - que seus partidários chamam de a teoria da "hierarquia normativa" ou a teoria da "revogação" - tem como ponto de partida, principalmente, a ideia da superioridade normativa das normas de jus cogens vis-à-vis o direito internacional "comum", que estabelece o princípio da imunidade jurisdicional dos Estados e seus agentes. Seja em conexão com, ou independentemente de, em consonância com alguns doutrinadores, quando um

\footnotetext{
328 INTERNATIONAL COURT OF JUSTICE. Application for Permission to Intervene by the
} Government of the Hellenic Republic. General List № 143, 13 January 2011. ㄲo 316. 
Estado viola as normas de jus cogens, sintomaticamente, renuncia ao seu direito de invocar a imunidade soberana. ${ }^{329}$

Contudo, os advogados da imunidade de jurisdição sustentam que, são inúmeros os tribunais que consideraram que as alegações de violação de normas imperativas de direito internacional não se sobrepõe a imunidade e, nem menos acarreta sua renúncia tácita. Essas jurisdições incluem nomeadamente os Estados Unidos, ${ }^{330}$ Canadá ${ }^{331}$ e Reino Unido. ${ }^{332}$ Uma apreciação semelhante foi assumida pelo Tribunal Europeu dos Direitos Humanos. ${ }^{333}$ Por fim, a evidência adicional para o reconhecimento limitado da teoria da "hierarquia normativa" é fornecida pela tomada de posição da Comissão de Direito Internacional. ${ }^{334}$

Uma série de razões podem ser, e têm sido, invocadas em apoio às decisões que negam o efeito revogatório das normas de jus cogens, além da objeção do próprio conceito de jus cogens. De acordo com Caplan, a ideia de que existe um conflito entre o jus cogens e imunidade do Estado é impreciso, uma vez que esta regra não é propriamente de caráter internacional, mas sim uma norma proveniente do direito interno. Assim, o mesmo sustenta que: "the regulation of state immunity falls, as a threshold matter, within the authoritative domain not of the foreign state defendant but, rather, of the forum state." ${ }^{335}$ Outros autores salientaram que a teoria

\footnotetext{
329 LEVI, J. A. As Between Princz and King: Reassessing the Law of Foreign Sovereign Immunity as Applied to Jus Cogens Violators. The Georgetown Law Journal, v. 86, p. 2703-2734, 1997-1998.

330 UNITED STATES COURT OF APPEALS. Hugo Princz v. Federal Republic of Germany. 26 F.3d 1166, 307 U.S.App.D.C. 102; Cf. BRÖHMER, J. State Immunity and the Violations of Human Rights. Amsterdã: Martinus Nijhoff, 1997. p. 76 et seq.

331 Vide e.g. COURT OF APPEAL OF ONTARIO. Bouzari v. Islamic Republic of Iran. Canada, 2004.

332 COURT OF APPEAL (CIVIL DIVISION). Suleiman Al-Adsani v Government of Kuwait and Others. United Kingdom, 1994.

333 EUROPEAN COURT OF HUMAN RIGHTS. Case of Al-adsani v. the United kingdom (Application no. 35763/97). Judgment, 21 November 2001.

334 UNITED NATIONS. A/C.6/54/L.12. Chairman of the Working Group, Report: Convention on Jurisdictional Immunities of States and their Property. 12 November 1999. No paragrafo 47 do document em tela, o Grupo de Trabalho declarou que: a relação entre a imunidade e as normas de jus cogens "did not seem to be ripe enough for the Working Group to engage in a codification exercise over it".

335 CAPLAN, L. M. State Immunity, Human Rights, and Jus Cogens: A Critique of the Normative Hierarchy Theory. American Journal of International Law, p. 741-781, 2003. p. 751.
} 
da hierarquia normativa implicaria má interpretação e distorção do estatuto interno aplicável. ${ }^{336}$

Inúmeros opositores da aplicação do conceito de jus cogens em relação à imunidade de jurisdição do Estado destacam a incompatibilidade de tal afirmação com o direito internacional, argumentando que simplesmente não há base para a proposição de que uma teoria controversa deva prevalecer sobre uma norma internacional estabelecida, tal como o princípio da imunidade do Estado. ${ }^{337}$ Além disso, alguns autores têm enfatizado que, a partir de um ponto de vista prático, a negação da imunidade soberana de um Estado seria politicamente insensato. Nesse sentido, Andreas Zimmermann defende que a:

[...] denial of immunity through an amendment to U.S. statutes eliminating the granting of sovereign immunity in cases of purported violations of international human rights would be both illegal under current public international law and politically unwise. Such should be avoided. ${ }^{338}$

Finalmente, alguns doutrinadores consideraram que a teoria da hierarquia normativa não constitui uma necessidade prática, como uma via processual alternativas, uma vez que encontram-se disponíveis outros meios processuais, como a reivindicação de comissões, o exercício da proteção diplomática e o acesso a um tribunal internacional de direitos humanos. ${ }^{339}$

Embora fundamental, segundo os advogados da imunidade, uma objeção a aplicação por analogia do conceito jus cogens como um obstáculo para o estabelecimento da imunidade do Estado não foi apresentada. Tal objeção é baseada no fato de que as duas regras alegadamente "conflitantes", ou seja, a norma que proíbe a violação de normas imperativas de direito internacional e a

336 PETSCHE, M. Jus Cogens as a vision of the International Legal Order. Penn State International Law Reports, v. 29, p. 233-273, 2010-2011.

337 Ibidem; POTESTA, M. The Alien Tort Statute: Comments on Current Issues: B. Immunity and Notable Preliminary Issues: State Immunity and Jus Cogens Violations: The Alien Tort Statute Against the Backdrop of the Latest Developments in the Law of Nations. Berkeley Journal of International Law, v. 28, p. 571-586., 2010.

338 ZIMMERMANN, A. Sovereing Immunity and Violations of International Jus Cogens. Michigan Joural of International Law, v. 16, p. 433-440, 1994-1995.

339 PETSCHE, M. op. cit., p. 233-273. 
norma que confere imunidade soberana aos Estados, não podem, do ponto de vista intelectual, possivelmente, estar "em conflito". 340

Nesse mesma esteira de pensamento, Emmanuel Voyiakis infere que, para:

Talk of any sort of ordering amongst legal rules makes sense only if those rules are in conflict at the level of substance. To say, for example, that the prohibition of torture suspends the rules of State immunity makes sense only if the two norms make conflicting substantive demands, for example, the prohibition of torture demands access to court whereas the rules of immunity serve to bar such access. In that sense, before considering whether the peremptory prohibition of torture may override the law of State immunity on account of its superior formal standing, one must consider whether the two rules do in fact make incompatible demands on States. As stated by both majority and minority, the 'pedigree' thesis is certainly incomplete. ${ }^{341}$

Desta feita, para o argumento de hierarquia normativa prevalecer, Sevrine Knuchel entende que seria necessário demonstrar que emergiu no direito internacional outra norma de jus cogens que obriga o Estado foro a proporcionar às vítimas reparação civil por atos cometidos no estrangeiro, perpetrados pelo Estado estrangeiro. Ademais, sublinha que, é duvidosa a existência de tal norma, atravez de lei ou tratado internacional consuetudinário, e muito menos o seu caráter imperativo. 342

Nesta toada, sublinhe-se que, no entendimento de alguns doutrinadores, apesar da doutrina da imunidade ter evoluído de uma teoria absoluta para uma relativa, nos casos de atos de gestão, não significa que com o passar dos anos surgirá uma nova exceção à imunidade se um Estado estrangeiro cometer graves violações de normas imperativas de direito internacional.

A corroborar o exposto, nas palavras de Roger O'Keefe:

For a start, the move from absolute to restrictive immunity was motivated, and eventually rendered compelling to courts (and, where relevant,

340 PETSCHE, M. Jus Cogens as a vision of the International Legal Order. Penn State International Law Reports, v. 29, p. 233-273, 2010-2011.

341 VOYIAKIS, E. Access to Court v. State Immunity. International and Comparative Law Quarterly, v. 52, p. 320, 2003.

342 KNUCHEL, S. State Immunity And The Promise Of Jus Cogens. Northwestern Journal of International Human Rights, v. 9, p. 160, 2011. 
legislatures), by pressing commercial considerations. And the sad, scandalous fact is that money will often speak much louder than considerations of human dignity.

Secondly, the change from absolute to restrictive immunity was possible without undermining the logic of the sovereign equality of states, the principle underpinning the doctrine of state immunity in both its forms. It remains the case under restrictive state immunity that sovereignty (inhering in the defendant state) cannot be made subject to sovereignty (inhering in the forum state, as manifest in the coercive authority of its courts). ${ }^{343}$

Concluindo, no ponto de vista soberanista, os defensores do afastamento da imunidade em casos de violações de normas de jus cogens estariam metaforicamente "batendo as cabeças contra uma parede de tijolos", que de tanto baterem pode vir a ruir, contudo essa possibilidade é bem improvável. O cenário mais plausível, de acordo com esses doutrinadores, é que as "batidas" conduzirão apenas à dor e frustração. ${ }^{344}$

\subsubsection{Argumentos humanistas}

Devido ao status especial do jus cogens, muitos advogados e doutrinadores dos direitos humanos defendem que a violação de tais normas implica no afastamento da imunidade de Estados estrangeiros ou de agentes públicos estrangeiros em processos resultantes de tais violações. São inúmeros as teorias que alicerçam essa tese, algumas das quais serão elucidadas a seguir.

\subsubsection{A Teoria da Hierarquia Normativa}

\footnotetext{
343 O'KEEFE, R. SYMPOSIUM: FOREIGN STATE IMMUNITY AT HOME AND ABROAD: State Immunity and Human Rights: Heads and Walls, Hearts and Minds. Vanderbilt Journal of Transnational Law, v. 44, p. 1029-1030, October 2011.

344 Ibidem, p. 1045.
} 
Esta tese, emanada do conceito de uma hierarquia normativa no direito internacional. ${ }^{345}$ Postula que os preceitos que regulam a imunidade dos Estados e seus agentes não fazem parte do rol de normas jus cogens, o que faz com que eles encontrem-se em uma classificação inferior na hierarquia das normas internacionais. 346 Consequentemente, o jus cogens prevalece em detrimento das regras de imunidade jurisdicional soberana. ${ }^{347}$

Tal disputa de valores ganha destaque no caso de Al-Adsani contra Reino Unido, o qual foi julgado pelo Tribunal Europeu dos Direitos Humanos (TEDH) em 2001. ${ }^{348}$ Neste caso, o Tribunal, por nove votos a oito, rejeitou a argumentação de que uma violação de norma peremptória de direito internacional sobre a proibição da tortura acarreta na negação da imunidade jurisdicional do Estado em ações civis. No entanto, em uma opinião divergente conjunta, seis juízes concordaram que as normas jus cogens estão acima das regras internacionais comuns, incluindo as regras sobre a imunidade do Estado:

By accepting that the rule on prohibition of torture is a rule of jus cogens, the majority recognise that it is hierarchically higher than any other rule of international law, be it general or particular, customary or conventional, with the exception, of course, of other jus cogens norms. For the basic characteristic of a jus cogens rule is that, as a source of law in the now vertical international legal system, it overrides any other rule which does not have the same status. In the event of a conflict between a jus cogens rule and any other rule of international law, the former prevails. The consequence of such prevalence is that the conflicting rule is null and void, or, in any event, does not produce legal effects which are in contradiction with the content of the peremptory rule. ${ }^{349}$

\footnotetext{
345 Para mais detalhes vide MACHADO, J. Direito internacional: do paradigma clássico ao pós-11 de Setembro. Coimbra: Coimbra Editora, 2006. p. 132 et seq.

346 FOX, H. The law of state immunity. Oxford: Oxford University Press, 2002. p. 537-538; KNUCHEL, S. State Immunity And The Promise Of Jus Cogens. Northwestern Journal of International Human Rights, v. 9, p. 149-183, 2011.

347 Cf. POTESTA, M. The Alien Tort Statute: Comments on Current Issues: B. Immunity and Notable Preliminary Issues: State Immunity and Jus Cogens Violations: The Alien Tort Statute Against the Backdrop of the Latest Developments in the Law of Nations. Berkeley Journal of International Law, v. 28 , p. $571-586,2010$.

348 EUROPEAN COURT OF HUMAN RIGHTS. Case of Al-adsani v. the United kingdom (Application no. 35763/97). Judgment. 21 November 2001.

349 EUROPEAN COURT OF HUMAN RIGHTS. Al-Adsani v. The United Kingdom, 35763/97, (Joint Dissenting Opinion of Judges Wildhaber, Costa, Cabral Barreto and Vajić), 21 November 2001. p. 26.
} 
Alguns defensores da teoria da hierarquia normativa argumentam que, uma regra processual de jus cogens pode ser obtida a partir do caráter peremptório da norma substantiva. Um vez que normas imperativas proíbem determinadas condutas, para o bem de toda a comunidade internacional, o seu status superior implicaria maior observância das normas internacionais. ${ }^{350}$ Deste modo, concluem que: "the material jus cogens rule also contains a procedural jus cogens rule prohibiting certain limits to its enforcement." 351

Com o intuito de afirmar o "caráter fundamental" do jus cogens, alguns doutrininadores argumentam que as questões atinentes a tais normas devem ser vislumbradas em função do objetivo por elas visado, que é indiscutivelmente mais amplo: "a função de normas imperativas, na esfera ora considerada, é impedir a impunidade das violações graves dos direitos humanos e do direito humanitário." 352

No caso Arrest Warrant, Juiz Al-Khasawneh sublinhou em seu voto dissidente que, o combate eficaz aos crimes graves passará a ter caráter jus cogens:

The effective combating of grave crimes has arguably assumed a jus cogens character reflecting recognition by the international community of the vital community interests and values it seeks to protect and enhance.

Therefore when this hierarchically higher norm comes into conflict with the rules on immunity, it should prevail. Even if we are to speak in terms of reconciliation of the two sets of rules, this would suggest to me a much more restrictive interpretation of the immunities of high-ranking officials than the Judgment portrays. Incidentally, such a restrictive approach would be much more in consonance with the now firmly established move towards a restrictive concept of State immunity, a move that has removed the bar regarding the submission of States to jurisdiction of other States often expressed in the maxim. ${ }^{353}$

\footnotetext{
350 Cf. ORAKHELASHVILI, A. State Immunity and Hierarchy of Norms: Why the House of Lords Got It Wrong. European Journal of International Law, v. 18, n. 5, p. 955-970, 2007; BARTSCH, K.; ELBERLING, B. Jus Cogens vs. State Immunity, Round Two: The Decisionof the European Court of Human Rights in the Kalogeropoulou et al. v. Greece and Germany Decision. German Law Journal, v. 4 , p. 477-492, 2003.

351 BARTSCH, K.; ELBERLING, B. op. cit., p. 487.

352 ORAKHELASHVILI, A. op. cit., p. 964-970

353 INTERNATIONAL COURT OF JUSTICE. Arrest Warrant of 11 April 2000 (Democratic Republic of the Congo v. Belgium). Dissenting opinion of Judge Al-Khasawneh. $\mathrm{n}^{\circ}=7$, p. 98.
} 
Concluindo, essa teoria preconiza que as regras jus cogens têm o condão de derrogar qualquer outra regra da hierarquia normativa que não tenha o mesmo status.

\subsubsection{A Teoria da "Cumplicidade"}

Outro argumento a favor do afastamento da imunidade dos Estados e de seus agentes baseia-se nos efeitos atribuídos às violações de jus cogens na lei de responsabilidade internacional do Estado. ${ }^{354} \mathrm{O}$ raciocínio é o seguinte: uma vez que o Projeto da Comissão Internacional de Justiça sobre Responsabilidade dos Estados por Atos Internacionalmente llícitos ${ }^{355}$ destacou o dever dos Estados de não reconhecerem violações de normas imperativas e, o de não auxiliarem o Estado inadimplente, concedendo imunidade, resultaria na cumplicidade com a violação jus cogens e atrairia para si a responsabilidade do Estado foro. ${ }^{356}$

Ad argumentandum, o Projeto de Artigos sobre Responsabilidade do Estado estipula que um Estado é internacionalmente responsável quando ajuda, auxilia, orienta, controla ou coage outro estado a cometer um ato internacionalmente ilícito, sob a condição de que se o fizer com o conhecimento de que tais práticas constituem atos ilícitos internacional. ${ }^{357}$ No caso de grave violação, por um Estado, de uma obrigação decorrente de uma norma imperativa de direito internacional geral, o Projeto Artigos sobre Responsabilidade do Estado também enfatiza o

\footnotetext{
354 ORAKHELASHVILI, A. State Immunity and Hierarchy of Norms: Why the House of Lords Got It Wrong. European Journal of International Law, v. 18, n. 5, p. 955-970, 2007

355 INTERNATIONAL LAW COMMISSION. Draft Articles on Responsibility of States for Internationally Wrongful Acts. Suplement №. 10 (A/56/10), chp.IV.E.1November 2001. art. 40 e arts. 4-6.

356 Cf. SCISO, E. Italian Judges' Point of View on Foreign States' Immunity. Vanderbilt Journal of Transnational Law, v. 44, p. 1201-1231, 2011.

357 INTERNATIONAL LAW COMMISSION. op. cit., arts. 16-18.
} 
especial dever dos Estados de não reconhecer como legítima a situação criada por tal violação. ${ }^{358}$

Esse entendimento é corroborado por algumas jurisdições nacionais, nomeadamente, o Tribunal de Cassação italiano utilizou essa teoria para fundamentar a sua decisão ao negar a imunidade da Alemanha por crimes cometidos durante a Segunda Guerra Mundial. 359 Do mesmo modo, no caso Prefecture of Voiotia vs. Federal Republic of Germany, o Tribunal de Primeira Instância grego afirmou que "the recognition of immunity for an act contrary to peremptory international law would amount to complicity of the national court to the promotion of an act strongly condemned by the international public order". 360

\subsubsection{A Teoria da "Qualificação"}

Outra argumentação de que a imunidade deve ser negada em caso de violações de normas de jus cogens, diz respeito ás condições que regem a concessão de recusa da imunidade do Estado. Entende-se que as violações do jus cogens não podem ser reconhecidas como atos soberanos, uma vez que o Estado ao viola-las deixou de considerar um conjunto de normas estabelecidas pela comunidade de Estados como um todo, para salvaguardar os seus interesses. Os atos praticados por Estados que violem jus cogens não faria parte da categoria de atos do Estado protegidos pela imunidade (acta jure imperii), portanto, a imunidade não deve ser concedida a tais Estados. ${ }^{361}$

358 INTERNATIONAL LAW COMMISSION. Draft Articles on Responsibility of States for Internationally Wrongful Acts. Suplement №. 10 (A/56/10), chp.IV.E.1November 2001. arts. 40, 41.

359 SUPREME COURT OF CASSATION OF ITALY. Ferrini v Germany, Appeal decision. №. 5044/4; ILDC 19 (IT 2004). 11 March 2004. para. 9; SENA, P. D.; VITTOR, F. D. State Immunity and Human Rights: The Italian Supreme Court Decision on the Ferrini Case. The European Journal of International Law, v. 16, n. 1, p. 89-112, 2005.

360 Cf. ORAKHELASHVILI, A. State Immunity and Hierarchy of Norms: Why the House of Lords Got It Wrong. European Journal of International Law, v. 18, n. 5, p. 964, 2007.

361 KNUCHEL, S. State Immunity And The Promise Of Jus Cogens. Northwestern Journal of International Human Rights, v. 9, p. 149-183, 2011. 
Essa teoria pode ser vislumbrada no caso Distomo, segundo o qual: "Acts of the state in breach of peremptory international law cannot qualify as sovereign acts of state." 362

O ilustre doutrinador Cançado Trindade, vai além em sua argumentação, asseverando que: atos perpetrados por Estados que configurem violações de normas imperativas de direito internacional não podem ser qualificadas como acta jure imperii, e nem menos acta jure gestionis, mas sim como delicta imperii. Isso porque, tais atos caracterizam crimes internacional. ${ }^{363}$

De acordo com o mesmo, nenhum Estado pode e nem nunca foi autorizado, a invocar a soberania para escravizar e / ou exterminar indivíduos, e, em seguida, para evitar as consequências legais escondendo-se de trás do escudo da imunidade do Estado. Ora, não há imunidade por graves violações dos direitos humanos e do direito internacional humanitário, por crimes de guerra e crimes contra a humanidade. A imunidade nunca foi concebida para tal iniquidade. ${ }^{364}$

Portanto, nas palavras de Cançado Trindade, atos de Estados que constituírem violações de normas jus cogens:

[...] are not to be considered acta jure imperii either; they are grave delicta, crimes. The distinction between acts jure imperii and acts jure gestionis, between sovereign or official acts of a State and acts of a private nature, is a remnant of traditional doctrines which are wholly inadequate [...]. Such traditional theories, in their myopia of State-centrism, forgot the lessons of the founding-fathers of the law of nations, pointing to the acknowledgement that individuals are subjects of the law of nations (droit des gens). ${ }^{365}$

\subsubsection{A Teoria da "Renúncia implícita"}

362 MULTI-MEMBER COURT OF LEVADIA. Case No. 137/1997, Distorno Massacre. 30 Oct. 1997. Revue Hellenique de droit international, v. 50, p. 599 et seq, 1997.

363 INTERNATIONAL COURT OF JUSTICE. Jurisdictional Immunities of the State (Germany v. Italy: Greece intervening). Dissenting opinion of Judge Cançado Trindade. Judgment of 3 February 2012. $\mathrm{n}$ os 177 et seq.

364 Ibidem, № 179.

365 Ibidem, № 178. 
A teoria ora estudada, que é uma das vertentes da teoria da qualificação, sustenta que os Estados ao violarem normas imperativas de direito internacional renunciam tacitamente ao seu direito de invocar a imunidade. Em consonância com o do direito internacional, um Estado pode fazer tal renúncia tácita se a sua intenção for claramente discernível. ${ }^{366}$ Consequentemente, reflete a Convenção sobre Imunidades Jurisdicionais dos Estados e dos seus bens, a existência de uma renúncia implícita está condicionada a alguma conduta axiomática, como iniciação ou intervenção no processo. ${ }^{367} \mathrm{Em}$ caso de violações de jus cogens, o argumento de renúncia tácita pode ser descrito da seguinte forma:

The existence of a system of rules that states may not violate implies that when a state acts in violation of such a rule, the act is not recognized as a sovereign act. When a state act is no longer recognized as sovereign, the state is no longer entitled to invoke the defense of sovereign immunity. Thus, in recognizing a group of peremptory norms, states are implicitly consenting to waive their immunity when they violate one of these norms. ${ }^{368}$

Este argumento foi confirmada pelo Supremo Tribunal grego no caso Distomo, nos seguintes termos: "When a state is in breach of peremptory rules of international law, it cannot lawfully expect to be granted the right of immunity. Consequently, it is deemed to have tacitly waived such right." 369

Além do jus cogens, a teoria da renúncia implícita também tem sido sustentada em relação aos tratados internacionais que protegem os direitos humanos. Alguns doutrinadores argumentam que a ratificação de um Estado de um tratado de direitos humanos, com a obrigação de fornecer remédios eficazes, equivaleria a uma renúncia à imunidade perante os tribunais internos, devido a

366 KNUCHEL, S. State Immunity And The Promise Of Jus Cogens. Northwestern Journal of International Human Rights, v. 9, p. 149-183, 2011.

367 UNITED NATIONS. Supplement No. 49 (A/59/49), United Nations Convention on Jurisdictional Immunities of States and Their Property. Adopted by the General Assembly of the United Nations on 2 December 2004. Official Records of the General Assembly, Fifty-ninth Session. arts. 7 (2), $8,9$.

368 BELSKY, A. C.; MERVA, M.; ROHT-ARRIAZA, N. Implied Waiver Under the FSIA: A Proposed Exception to Immunity for Violations of Peremptory Norms of International Law. California Law Review, v. 77 , p. 365 et seq, 1989. p.394

369 MULTI-MEMBER COURT OF LEVADIA. Case No. 137/1997, Distorno Massacre. 30 Oct. 1997.

Revue Hellenique de droit international, v. 50, p. 599 et seq, 1997. 
anuência do Estado em se comprometer a respeitas as normas jurídicas estabelecidos no tratado. ${ }^{370}$

\subsubsection{A Teoria da "Jurisdição Universal"}

Imunidade do Estado passou também a ser contestada sob o argumento da mesma ser incompatível com o princípio da jurisdição universal concatenado com a violação do jus cogens. ${ }^{371}$ Uma vez que, as normas imperativas são de interesse da comunidade internacional, sintomaticamente todos os Estado tem interesse em reprimir as violações de tais preceitos. Assim sendo, o direito internacional tem reconhecido que os Estados possuiriam o condão legal de exercer jurisdição sobre essas violações, mesmo sem possuir vínculo territorial ou nacionalidade. ${ }^{372}$

De acordo com a história, os Estados já contavam com a prerrogativa de declarar jurisdição sobre crimes como a pirataria que ocorressem em alto mar. ${ }^{373}$ Defende-se o argumento de que os Estados, com o intuito de salvaguardar os interesses da comunidade internacional, devem possuir o poder de exercer a prerrogativa de jurisdição universal sobre violações de jus cogens perpetrados por outro Estado ou seus agentes. ${ }^{374}$

O conflito entre o estabelecimento da jurisdição universal e a reivindicação da imunidade foi salientada por vários Lordes, no caso Pinochet. Como a Convenção

${ }^{370}$ BIANCHI, A. Denying State Immunity to Violators of Human Rights. Austrian Journal of Public and International Law, v. 46, p. 195-229, 1994. p. 213-214.

371 Cf. ORAKHELASHVILI, A. State Immunity and Hierarchy of Norms: Why the House of Lords Got It Wrong. European Journal of International Law, v. 18, n. 5, p. 960-964, 2007; AKANDE, D. International Law Immunities and the International Criminal Court. American Journal of International Law, v. 98 , p. 415, 2004.

372 DONOVAN, D. F.; ROBERTS, A. The Emerging Recognition of Universal Civil Jurisdiction. American Journal of International Law, v. 100, p. 142-163, 2006. p. 148.

${ }^{373}$ Este princípio consuetudinário foi posteriormente codificado em Convenções Internacionais. Vide UNITED NATIONS. Geneva Convention on the High Seas. Adopted at Geneva, Switzerland on 29 April 1958. art. 19.

374 KNUCHEL, S. State Immunity And The Promise Of Jus Cogens. Northwestern Journal of International Human Rights, v. 9, p. 149-183, 2011. 
contra a Tortura e Outras Penas ou Tratamentos Cruéis, Desumanos ou Degradantes exige que os Estados partes extraditem ou punam os supostos infratores, ${ }^{375}$ alguns dos Lordes, no caso supracitado, argumentaram que a imunidade ratione materiae de um ex-chefe de Estado pode ser revogada por esse regime. ${ }^{376}$ Lorde Browne-Wilkinson, e.g. afirmou que, se a imunidade ratione materiae fosse reconhecida a autoridades estatais:

The whole elaborate structure of universal jurisdiction over torture committed by officials is rendered abortive and one of the main objectives of the Torture Convention - to provide a system under which there is no safe haven for torturers - will have been frustrated. In my judgment all these factors together demonstrate that the notion of continued immunity for ex-heads of state is inconsistent with the provisions of the Torture Convention. ${ }^{377}$

Nesse mesmo diapasão, Lorde Phillips of Worth Matravers assevera que:

[...] on the simple basis that no established rule of international law requires state immunity ratione materiae to be accorded in respect of prosecution for an international crime. International crimes and extra- territorial jurisdiction in relation to them are both new arrivals in the field of public international law. I do not believe that state immunity ratione materiae can coexist with them. The exercise of extraterritorial jurisdiction overrides the principle that one state will not intervene in the internal affairs of another. It does so because, where international crime is concerned, that principle cannot prevail. An international crime is as offensive, if not more offensive, to the international community when committed under colour of office. Once extraterritorial jurisdiction is established, it makes no sense to exclude from it acts done in an official capacity. ${ }^{378}$

A ideia fundamental da jurisdição universal pode ser definida como um esforço comum em face das atrocidades cometidas. Nesse sentido os magistrados Higgins, Kooijmans and Buergenthal, afirmaram, em parecer separado do caso Arrest Warrant, que:

The underlying idea of universal jurisdiction properly so-called (as in the case of piracy. and possibly in the Geneva Conventions of 1949), as well as the aut dedere aut prosequi variation, is a common endeavour in the face of

375 Cf. UNITED NATIONS. A/RES/39/46. General Assembly, Convention against Torture and Other Cruel, Inhuman or Degrading Treatment or Punishment: resolution / adopted by the General Assembly, 10 December 1984

376 Cf. HOUSE OF LORDS. Regina v. Bow Street Metropolitan Stipendiary Magistrate and Others, ex parte Pinochet Ugarte (no. 3). 2000. 1 A.C. 147.

377 Ibidem. p. 206.

378 Ibidem. p. 290. 
atrocities. The series of multilateral treaties with their special jurisdictional provisions reflect a determination by the international community that those engaged in war crimes, hijacking, hostage taking, torture should not go unpunished. ${ }^{379}$

Comporta, assim, estabelecer que, para cumprir esse compromisso, cada Estado tem o mesmo direito de exercer jurisdição sobre a violação, devido à sua condenação universal. Neste contexto, o interesse da comunidade internacional prevalece em detrimento do princípio da não intervenção.

Repise-se por derradeiro que, as teorias supra elucidadas são algumas das bases sustentadoras da tese segundo a qual a imunidade não deve prevalecer quando existir uma violação de normas imperativas de direito internacional.

\subsection{Discussão e tomada de posição}

O primeiro ponto que deve ser sopesado nesse passo é a evolução do direito internacional. Nos últimos séculos, dentre todos os ramos do direito, o direito internacional é o que mais tem evoluído, influenciando todos os aspectos da vida humana.

Os princípios e normas basilares do direito internacional têm de ser situados como padrão de conduta natural e base inquestionável para estudos e escritos a respeito da história humana, a seu tempo. ${ }^{380}$ Nesse sentido, Antonio Gomez Robledo observa que: "um direito particular, subjetivo, está sempre em função da ordem jurídica total ou do sentimento jurídico de cada época, e que subsiste ou se extingue segundo a evolução desses grandes conjuntos, no seio dos quais se encontra essa inserção" 381

379 INTERNATIONAL COURT OF JUSTICE. Arrest Warrant of 11 April 2000 (Democratic Republic of the Congo v. Belgium). Joint separate opinion of Judges Higgins, Kooijmans and Buergenthal. para. 51 .

${ }^{380}$ Cf. TOYNBEE, A. Um estudo de história. Lisboa: Editora Ulisseia, 1964.

381 GOMEZ ROBLEDO, A. apud ACCIOLY, H.; SILVA, G. E. D. N.; CASELLA, P. B. Manual de Direito Internacional Público. São Paulo: Saraiva, 2010. 
O ilustre doutrinador Cançado Trindade assinala como marco da evolução:

[...] na medida em que o direito internacional, a partir de meados do século $\mathrm{XX}$, logrou desvencilhar-se das amarras do positivismo voluntarista, que teve uma influência nefasta na disciplina e bloqueou por muito tempo sua evolução. O direito não é estático, nem tampouco opera no vácuo. Não há como deixar de tomar em conta os valores que formam o substratum das normas jurídicas. O direito internacional superou o voluntarismo ao buscar a realização de valores comuns superiores, premido pelas necessidades da comunidade internacional. ${ }^{382}$

"O circunstancial pertence à política" ${ }^{883}$ assegurava Vattel ao tratar do "direito das gentes necessário" ${ }^{384}$ e desenvolve a fundamentação do conceito:

[...] é da maior importância para as nações que o direito das gentes, base de sua própria tranquilidade, seja respeitado universalmente. Se alguma nação espezinhar abertamente esse direito, todas podem e devem insurgirse contra ela, e ao reunirem suas forças, para punir esse inimigo comum, elas estão cumprindo seus deveres, para consigo mesmas e para com a sociedade humana, da qual são membros. ${ }^{385}$

O então denominado direito das gentes necessário de Vattel, seria, hoje, o chamado direito internacional cogente (jus cogens) ou normas imperativas de direito internacional. ${ }^{386}$ Dentre elas, destacam-se as normas do sistema de direito internacional dos direitos humanos.

Os direitos humanos, no entendimento do Instituto de Direito Internacional, são a expressão direta da dignidade e da personalidade humana. A obrigação, para os estados, de assegurar o respeito, decorre do próprio reconhecimento dessa dignidade, já proclamada pela Carta das Nações Unidas e pela Declaração Universal dos Direitos do Homem. Essa obrigação internacional é, segundo a formulação utilizada pela Corte Internacional de Justiça, obrigação que se reveste de

382 TRINDADE, A. A. C. Os rumos do direito internacional contemporâneo: de um jus inter gentes a um novo jus gentium no século XXI. In: TRINDADE, A. A. C. O direito internacional em um mundo em transformação: ensaios, 1976-2001. São Paulo: Renovar, 2002. p. 1087.

383 VATTEL, E. D. O direito das gentes. Brasília: Editora Universidade de Brasília: Instituto de Pesquisa de Relações , 2004. p. 30.

384 Ibidem. p. 3.

385 Ibidem. p. 180-181.

386 Cançado Trindade advertiu para a "manifesta incompatibilidade com conceito de jus cogens da concepção voluntarista do Direito Internacional, que não é capaz sequer de explicar a formação de regras do direito internacional geral". TRINDADE, A. A. C. op. cit., p. 1088. 
caráter erga omnes; como tal, incumbe a todos e a cada um dos Estados, perante o conjunto da sociedade internacional, como todo; ao mesmo tempo, todos os Estados têm interesse jurídico na proteção dos direitos do homem. Essa obrigação implica, ademais, o dever e solidariedade entre todos os Estados, visando assegurar, o mais rapidamente possível, a proteção, universal e eficaz, dos direitos do homem. ${ }^{387}$

Ademais, o Instituto acrescenta que, nenhum Estado, ao violar essa obrigação internacional de proteção, pode se eximir de sua responsabilidade internacional sob a alegação de que tal domínio constituía, essencialmente, matéria de sua competência nacional, ou de seu domínio reservado. ${ }^{388}$

O Instituto de direito internacional (na sessão de Cracóvia, em 2005), mais uma vez, sublinha que os valores fundamentais da comunidade internacional são violados pelos crimes internacionais graves, tais como definidos pelo direito internacional, e, desse modo, salienta ter a competência universal como escopo proteger tais valores, especialmente a vida humana, a dignidade humana e a integridade física, ao permitir que sejam processados os crimes internacionais. ${ }^{389}$

Comporta, assim, estabelecer que, apesar do sistema internacional permanecer, hoje, como ontem, o direito da sociedade dos estados, o sistema normativo internacional, com certeza, mudou de conteúdo.

Resta diáfano que, em decorrência dos direitos do homem e do direito de autodeterminação dos povos transcendemos a problemática tradicional do direito internacional, que é a das relações entre Estados, onde, como escrevera Michel Virally, a soberania põe limites à soberania, e onde o progresso do direito se faz com base na reciprocidade.

Em decorrência de tais desenvolvimentos, de fato a soberania vai, doravante, encontrar-se limitada por direitos pertencentes a outros sujeitos de direito, além dos Estados. O direito internacional penetra no âmago da soberania: nas relações do

\footnotetext{
387 INSTITUTE OF INTERNATIONAL LAW. The Protection of Human Rights and the Principle of Non-intervention in Internal Affairs of States. (Session of Santiago de Compostela - 1989). art 10.

388 Ibidem. Artigo $2^{\circ}$.

389 INSTITUTE OF INTERNATIONAL LAW. Universal criminal jurisdiction with regard to the crime of genocide, crimes against humanity and war crimes. (Krakow Session - 2005).
} 
Estado com os seus nacionais e, de modo mais vasto, entre o aparelho do Estado e a população; portanto, entre esses dois elementos constitutivos do Estado, pode-se extrair a conclusão de Virally, no sentido de que todos esses desenvolvimentos do direito internacional remodelaram o perfil da soberania. 390

O advento da noção de norma de jus cogens veio evidenciar que até mesmo a vontade dos Estados deve encontrar limites, e que estes não poderiam atribuir quaisquer efeitos a determinado tratado. ${ }^{391}$

Francisco de Vitoria, na lição sobre o poder civil, sublinhou que:

[...] O direito das gentes (ius gentium) não tem somente força de pacto ou de convenção entre os homens, mas possui, igualmente, força de lei. $O$ mundo inteiro, na verdade, que, de certo modo, constitui uma república, tem o poder de levar leis justas e ordenadas para o bem de todos, tais como são as do direito das gentes. Consequentemente, quando se trata de questões graves, nenhum Estado pode se considerar desvinculado do direito das gentes, pois este é colocado pela autoridade do mundo inteiro. ${ }^{392}$

Assim sendo, o desenvolvimento mais relevante no direito internacional faz-se no sentido da humanização do direito internacional, para resgatar a condição central do ser humano no direito internacional, mediante o surgimento e a consolidação de sistema internacional de proteção dos direitos fundamentais.

Desta feita, pode ser vislumbrada em meio a tal evolução e transformação do direito internacional uma revolução Copernicana. Isso devido à mudança do centro de gravitação do direito Internacional, que anteriormente tinha o Estado como o principal sujeito de direito internacional (geocentrismo), e que coloca hoje o indivíduo em tal posição (heliocentrismo).

Kant já defendia que o indivíduo era um fim em si mesmo:

Admitindo, porém que haja alguma coisa cuja existência em si mesma tenha valor absoluto e que, como fim em si mesmo, possa ser a base de leis determinadas, nessa coisa e só nela é que estará a base de um possível

\footnotetext{
390 ACCIOLY, H.; SILVA, G. E. D. N.; CASELLA, P. B. Manual de Direito Internacional Público. São Paulo: Saraiva, 2010.

391 Idem.

392 VITORIA, F. D. Political writings: Cambridge Texts in the History of Political Thought. Cambridge: Cambridge University Press, 1995. p. 40.
} 
imperativo categórico, que dizer de uma lei prática. Ora digo eu: O homem, e, duma maneira geral, todo o seu racional, existe como fim em si mesmo, não só como meio para o uso arbitrário desta ou daquela vontade. Pelo contrário, em todas as suas ações, tantos nas que se dirigem a ele mesmo como nas que se dirigem a outros seres racionais, ele tem sempre que ser considerado simultaneamente como fim. ${ }^{393}$

Contudo, a recente decisão do Tribunal no caso Ferrini trouxe um retrocesso, inconcebível, na esfera dos direitos humanos, ao declarar que: mesmo em casos de violações graves aos direitos humanos, um país não pode ser julgado pelo Judiciário de outro, ou seja, ainda nestes casos, a imunidade dos Estados prevalece. ${ }^{394}$ Urge, desse modo, tecermos algumas considerações.

Todos os desenvolvimentos direcionados a proteção dos direitos humanos vão além da dimensão interestatal estrita e tradicional. Por isso, nos parece estranho, se não surreal, que o domínio da imunidade do Estado não tenha evoluído pari passu a tais desenvolvimentos significativos, permanecendo alheio a eles. Não se pode abordar casos que envolvam graves violações dos direitos humanos e do direito internacional humanitário, sem dar-se extrema atenção aos valores humanos fundamentais. Contrariamente ao que o positivismo jurídico preconiza, a lei e a ética andam, inelutavelmente, de mãos dadas, e isso deve ser mantido para que a justiça possa ser fielmente realizada, a nível nacional e internacional.

A invocação das "considerações elementares de humanidade" não pode ser retórica, deixando de acautelar a coerência ao não prever nem abordar as consequências da aplicação destas considerações na prática. Além disso, não se deve buscar uma visão assaz restritiva da opinio juris, reduzindo-o ao elemento subjetivo do costume e distanciando-o dos princípios gerais do direito, até o ponto de não sopesá-las. ${ }^{395}$

${ }^{393}$ KANT, I. Fundamentação da metafísica dos costumes: texto integral. Porto : Areal, 2005. p. 68. 394 INTERNATIONAL COURT OF JUSTICE. Jurisdictional Immunities of the State (Germany v. Italy: Greece intervening). Judgment, I.C.J. Reports 2012.

395 Cf. INTERNATIONAL COURT OF JUSTICE. Jurisdictional Immunities of the State (Germany v. Italy: Greece intervening). Dissenting opinion of Judge Cançado Trindade. Judgment of 3 February 2012. 
Nesse passo, é imperioso enaltecer que, as normas imperativas de direito internacional geral vão além do estágio consuetudinário, atingindo patamar mais estável dos princípios gerais do direito internacional. ${ }^{396}$

No caso ora estudado, os atos praticados no território do Estado do foro por parte das forças armadas de um Estado estrangeiro (como o Tribunal os retrata), são atos cuja ilegalidade foi reconhecida pelo próprio Estado responsável, a Alemanha, em todas as fases do processo.

Tais atos não configuram acta jure imperii, como o Tribunal os qualifica, mas sim atos ilícitos (delicta imperii), atrocidades, crimes internacionais da maior gravidade, cingindo a responsabilidade do Estado e dos indivíduos que os praticaram. A tradicional distinção entre atos jure imperii e jure gestionis não se aplica no presente caso, devido à gravidade dos atos.

Os principios punctum pruriens no caso Ferrini são: o princípio da humanidade e o princípio da dignidade da pessoa humana. A imunidade do Estado não pode, ao nosso entender, ser indevidamente colocada acima de responsabilidade do Estado por crimes internacionais e, inelutavelmente, sua consequência jurídica, o dever do Estado responsável de reparação às vítimas.

Como já indicado, a jurisprudência do Tribunal de Haia defende o entendimento que, por uma questão de princípios, uma violação do direito internacional e o correspondente dever de fornecer reparação formam um conjunto indissociável, de tal maneira que cessem suas consequências.

A Imunidade de Estado, de acordo com Cançado Trindade, não é um direito, mas sim uma prerrogativa ou privilégio, por isso, não pode ser acolhido de tal forma que acarrete uma manifesta injustiça. ${ }^{397}$

\footnotetext{
${ }^{396}$ Cf. ACCIOLY, H.; SILVA, G. E. D. N.; CASELLA, P. B. Manual de Direito Internacional Público. São Paulo: Saraiva, 2010.

397 INTERNATIONAL COURT OF JUSTICE. Jurisdictional Immunities of the State (Germany v. Italy: Greece intervening). Dissenting opinion of Judge Cançado Trindade. Judgment of 3 February 2012.
} 
O Tribunal, ao deliberar sobre o caso ora estudado, utilizou-se da metodologia do positivismo jurídico, atendando-se aos fatos, afastou-se dos valores. O emprego de tal método gera a fossilização do direito internacional, causando uma procrastinação do seu desenvolvimento, ao invés da sua evolução progressivo, como seria de se esperar.

O emprego de tal concepção, em alguns casos, como no da imunidade de jurisdição, pode levar a manifesta injustiça.

No presente julgamento, a maioria do Tribunal parte do pressuposto errôneo de que nenhum conflito existe, ou pode existir entre as regras do jus cogens substantivas e das regras processuais da imunidade do Estado. Esta suposição tautológica leva o Tribunal a sua defesa da imunidade Estado, mesmo nas graves circunstâncias do presente caso. Existe, portanto, um conflito material e, em consonância coma a decisão dissidente do juiz Cançado Trindade, o raciocínio do Tribunal leva a uma desconstrução do fundamento do jus cogens, privando-o de seus efeitos e consequências legais. ${ }^{398}$

Já passou da hora de dar à norma jus cogens à atenção que a mesma exige e merece. A sua desconstrução, como no presente caso, é em detrimento não só dos indivíduos vítimas de graves violações dos direitos humanos e do direito internacional humanitário, mas também do próprio direito internacional contemporâneo.

Nas palavras do magistrado Cançado Trindade:

What jeopardizes or destabilizes the international legal order, are the international crimes, and not the individual suits for reparation in the search for justice. What troubles the international legal order, are the cover-up of such international crimes accompanied by the impunity of the perpetrators, and not the victims' search for justice? When a State pursues a criminal policy of murdering segments of its own population, and of the population of other States, it cannot, later on, place itself behind the shield of sovereign immunities, as these latter were never conceived for that purpose. 399

\footnotetext{
398 INTERNATIONAL COURT OF JUSTICE. Jurisdictional Immunities of the State (Germany v. Italy: Greece intervening). Dissenting opinion of Judge Cançado Trindade. Judgment of 3 February 2012.

399 lbidem.
} 
Em suma, defendemos a tese da inexistência da prerrogativa ou privilégio da imunidade jurisdicional do Estado, nos casos que abarquem violações graves de jus cogens, como e.g. os crimes internacionais, massacres da população civil, e deportação de civis e prisioneiros de guerra sujeitos a trabalho escravo, para os quais não pode haver imunidades. 


\section{CONCLUSÕES}

Resta cristalina que, o direito internacional, no decorrer dos anos e de acordo com o sentimento jurídico de cada época, foi o ramo do direito que mais sofreu alterações. Uma das mudanças fulcrais mais importantes deu-se com a transferência do seu centro de gravidade para o indivíduo, antes ocupada pelo Estado (revolução copernicana). Tal mudança corrobora a importância do jus cogens para a comunidade internacional.

A questão que se descortina é, se o direito internacional passou por mudanças intrínsecas para acautelar os direitos humanos, por que a imunidade do Estado não deve ser afastada em casos de violações graves de direitos humanos?

Devemos levar em consideração que, quando um Estado comete atos que vem de encontro com as normas imperativas de direito internacional, os mesmo não devem ser sopesados como atos de império, mas sim como atos ilícitos que geram consequências jurídicas. Uma vez que tais atos não caracterizam atos soberanos, a imunidade não pode, nessa conjuntura, ser sustentada.

É mister desvencilharmo-nos das amarras do conservadorismo jurídico, que ainda considera a soberania como imutável. Diferentemente do que é defendido pelos doutrinadores conservadores, a soberania é mais precisamente definida como "a complex of various forms of power and independence...that a state needs in order to be a good state." 400

Não defendemos que a soberania dos Estados deve ser negada, contudo os efeitos decorrentes deste estatuto jurídico devem ser reavaliados para dar lugar a considerações básicas de justiça.

\footnotetext{
400 ENDICOTT, T. The Logic of Freedom and Power. In: BESSON, S.; TASIOULAS, J. The
} Pholosophy of Interational Law. Oxford: Oxford University Press, 2010. p. 252 
As normas jus cogens, ponderada como princípios normativos essenciais, reconhecidos pela comunidade internacional dos Estados no seu conjunto, são indicativos de um "bom estado"; e um "bom estado" serve o povo de seu território sem cometer tortura, por exemplo. As normas imperativas (juntamente com outras considerações) contribuem para o delineamento das formas de poderes e a independência que compõem a soberania do Estado. A prática de imunizar um Estado é uma forma de independência necessária para que o Estado seja um "bom estado"? No caso de processos decorrentes da violação das normas que são universalmente reconhecidas como essenciais, a resposta está longe de ser um prejulgamento. Já em 1951, um doutrinador expressou dúvidas sobre esta questão:

At a period in which in enlightened communities the securing of the
rights of the individual, in all their aspects, against the state has
become a matter of special and significant effort, there is no longer a
disposition to tolerate the injustice which may arise whenever the state-our
own state or a foreign state-screens itself behind the shield of immunity
in order to defeat a legitimate claim. ${ }^{401}$

A negação da imunidade é comprovada pela primazia da norma violada e os seus valores subjacentes. $O$ afastamento da imunidade não é efeito provocado pela norma imperativa. Pelo contrário, o jus cogens oferece um terreno no qual basear tal negação, o que, se seguida de uma prática futura, pode se transformar em uma nova norma de direito internacional consuetudinário.

Nesse diapasão, a decisão do Tribunal Internacional de Justiça no caso Ferrini, segundo o qual nenhum Estado pode ser processado em tribunais estrangeiros mesmo em casos de violações grave de direitos humanos, deve servir para abrir os nossos olhos acerca da necessidade de uma mudança definitiva de paradigma. Colocando o individuo e seus direitos fundamentais acima de qualquer outro preceito que venha de encontro a eles. Os direitos humanos, que são normas cogentes, não devem ser marginalizados por uma mera prerrogativa ou privilégio de um Estado, nesse caso a imunidade jurisdicional do Estado.

Comporta, assim, estabelecer que, devido o papel desempenhado pelas normas imperativas, qualquer Estado que as viole não deve se esconder por detrás

401 LAUTERPACHT, H. The Problem of Jurisdictional Immunities of Foreing States. British Yearbook of Internationl Law, v. 2 
da imunidade jurisdicional do Estado. O Estado infrator deve ser responsabilizado juridicamente por tais atos ilícios. 


\section{BIBLIOGRAFIA}

ACCIOLY, H.; SILVA, G. E. D. N.; CASELLA, P. B. Manual de Direito Internacional Público. São Paulo: Saraiva, 2010.

AKANDE, D. International Law Immunities and the International Criminal Court. American Journal of International Law, v. 98 , p. 407-433, 2004.

ALMEIDA, F. F. D. Direito Internacional Público. Coimbra: Coimbra Editora, 2003.

AMARAL JÚNIOR, A. D. Curso de Direito Internacional Público. 2. ed. São Paulo: Atlas, 2011.

ARROYO, D. F. Derecho internacional privado de los estados del Mercosur: Argentina, Brasil, Paraguay, Uruguay. Buenos Aires: Zavalia, 2003.

ASSEMBLEIA NACIONAL DA FRANÇA. Declaração de Direitos do Homem e do Cidadão. França, 26 de agosto de 1789. Disponível em: <http://pfdc.pgr.mpf.gov.br/atuacao-e-conteudos-de-apoio/legislacao/direitoshumanos/declar_dir_homem_cidadao.pdf>

BAPTISTA, E. C. Direito internacional público: Sujeitos e responsabilidade. Coimbra: Almedina, v. II, 2004.

BAPTISTA, E. C. lus cogens em direito internacional. Lisboa: LEX, 1995.

BARROSO, I. M. O acordo com vista à prática de genocídio: o conceito, os requisitos e o fundamento da punição do contrato criminal. Livraria Almedina, 2003. Separata de : Estudos em Homenagem ao Professor Doutor Inocêncio Galvão Telles, Vol. 5.

BARTSCH, K.; ELBERLING, B. Jus Cogens vs. State Immunity, Round Two: The Decisionof the European Court of Human Rights in the Kalogeropoulou et al. v. Greece and Germany Decision. German Law Journal, v. 4 , p. 477-492, 2003. 
BASSIOUNI, M. C. Legal control of international terrorism: A policy-oriented assessment. Harvard International Law Journal, v. 43, p. 83-103, 2002.

BASTIN, L. Case Note: International Law and the International Court of Justice's decision in jurisdictional immunities of the state. Melbourne Journal of International Law, n. 13, p. 774, November 2012.

BATENKAS, I. Prefecture of Voiotia v. Federal Republic of Germany. Case No. 137/1997. The American Journal of International Law, v. 92, n. 4, p. 765-768, 1998.

BELSKY, A. C.; MERVA, M.; ROHT-ARRIAZA, N. Implied Waiver Under the FSIA: A Proposed Exception to Immunity for Violations of Peremptory Norms of International Law. California Law Review, v. 77 , p. 365 et seq, 1989.

BIANCHI, A. Denying State Immunity to Violators of Human Rights. Austrian Journal of Public and International Law, v. 46, p. 195-229, 1994.

BICUDO, H. Direitos Humanos e sua proteção. São Paulo: FDT, 1997.

BISHOP, W. W. J. New United States Policy Limiting Sovereign Immunity. The American Journal of International Law, v. 47, p. 93-106, 1953.

BOBBIO, N. A Era dos Direitos. Nova. ed. Rio de Janeiro: Elsevier, 2004.

BOGGIANO, A. Derecho internacional: derecho de las relaciones entre los ordenamientos jurídicos y derechos humanos. Buenos Aires: La Ley, 2001.

BOUTROS, BOUTROS-GHALI. Un programa de paz: Diplomacia preventiva, establecimiento de la paz y mantenimiento de la paz. Memorial del secretario General sobre la labor de la organización. (ONU A/47/277 - S/2411, 17 junio 1992).

BRADLEY, C. A.; GOLDSMITH, J. L. Foreign Sovereign immunity, individual officials, and human rights litigation. Green Bag, v. 2, n. 13, p. 9, Autumn 2009.

BRIERLY, J. L. Direito internacional. 4ํ. ed. Lisboa: Fundação Calouste Gulbenkian, 1979. 
BRÖHMER, J. State Immunity and the Violations of Human Rights. Amsterdã: Martinus Nijhoff, 1997.

BROWNLIE, I. Princípios de direito internacional público. Lisboa: Fundação Calouste Gulbenkian, 1997.

BUNDESGESETZBLATT. Statutes For The Foundation "Remembrance, Responsibility and the Future". 2 August 2000. Disponível em: $<$ http://www.stiftung-evz.de/eng/the-foundation/statutes.html>

CAMILLERI, J. A.; FALK, J. The end of sovereignty?: The politics of a shrinking and fragmenting world. Aldershot: Edward Elgar, 1992.

CAPLAN, L. M. State Immunity, Human Rights, and Jus Cogens: A Critique of the Normative Hierarchy Theory. American Journal of International Law, p. 741-781, 2003.

CASSESE, A. et al. International criminal law: cases and commentary. Oxford; New York: Oxford University Press, 2011.

. International criminal law. Oxford: Oxford University Press, 2003.

. International law. 2a . ed. Oxford: Oxford University Press, 2005.

CHARLEROY CIVIL COURT. Sociéteé Monnoyer v. France. Belgium, 1927.

CHARLESWORTH, H.; CHINKIN, C. The boundaries of international law: a feminist analysis. Manchester: Manchester University Press, 2000.

COMPARATO, F. K. A afirmação histórica dos direitos humanos. 6. ed. São Paulo: Saraiva, 2008.

CORNU, G. Vocabulaire juridique. 7ª ed. Paris: PUF, 2005.

CORTE DI CASSAZIONE. Morellet v. Governo Danese, Italy, 1882. American Journal of International Law. v. 26, Suplement (1932).

CORTE INTERAMERICANA DE DERECHOS HUMANOS. Caso Goiburú y otros Vs. Paraguay. Sentencia de 22 de septiembre de 2006 (Fondo, Reparaciones y 
Costas)

Disponível

em:

<http://www.tc.gob.pe/corte_interamericana/seriec_153_esp.pdf>

COUR DE CASSATION PREMIERE CHAMBRE CIVILE. Bucheron v. République Fédérale d'Allemagne. Paris, 2003. Disponível em: <http://www.juricaf.org/arret/FRANCE-COURDECASSATION-20031216-0245961>

COUR DE CASSATION. Chemins des fer Liegeois-Luxembourg v. Etat nérderlandais. Bélgica, 1903.

COURT OF APEAL. Rau, van den Abeele et Cie v. Duruty, decision confirmed by the Court of Appeal. Ghent, 1879.

COURT OF APPEAL (CIVIL DIVISION). Suleiman Al-Adsani v Government of Kuwait and Others. United Kingdom, 1994. Disponível em: $<$ http://www.dipublico.com.ar/english/suleiman-al-adsani-v-government-of-kuwaitand-others/>

COURT OF APPEAL OF ONTARIO. Bouzari v. Islamic Republic of Iran. Canada, 2004. Disponível em: <http://canlii.ca/t/1hdv4>

COURT OF APPEAL OF POITIERS. Roumania (Sate of Roumania) v. Aricastre, France. Poitiers, 1949.

COURT OF APPEAL. Trendtex Trading Corporation v. Central Rank Of Nigeria. England, 1977. Disponível em: <http://www.uniset.ca/other/css/19772WLR356.htmL>

CRAWFORD, J. The international law commission's articles on state responsibility: introduction, text and commentaries. Cambridge: Cambridge University Press, 2002.

CUNHA, J. D. S.; PEREIRA, M. D. A. D. V. Manual de direito Internacional Público. Coimbra: Almedina, 2004.

DAMROSCH, L. F. Symposium: Foreign State Immunity at Home and Abroad: Changing the International Law of Sovereign Immunity Through National Decisions. Vanderbilt Journal of Transnational Law, n. 44, p. 1185, November 2011. 
DINAMARCO, C. R. Instituições de direito processual civil. 4. ed. São Paulo: Malheiros, v. 1, 2004.

DIRECÇÃO-GERAL DA POLÍTICA DE JUSTIÇA. Convenção Europeia sobre a Imunidade dos Estados (STE 074). Portugal, 1979. Disponível em: <http://www.dgpj.mj.pt/sections/relacoes-internacionais/copy_of_anexos/convencaoeuropeia-sobre3197/>

DIXON, M. Textbook on international law. 5․ ed. Oxford: Oxford University Press, 2005.

DONOVAN, D. F.; ROBERTS, A. The Emerging Recognition of Universal Civil Jurisdiction. American Journal of International Law, v. 100, p. 142-163, 2006.

ENDICOTT, T. The Logic of Freedom and Power. In: BESSON, S.; TASIOULAS, J. The Pholosophy of Interational Law. Oxford: Oxford University Press, 2010. p. 245- 259.

EUROPEAN COURT OF HUMAN RIGHTS. Al-Adsani v. The United Kingdom, 35763/97, (Joint Dissenting Opinion of Judges Wildhaber, Costa, Cabral Barreto and Vajić), 21 November 2001. Disponível em: $<$ http://www.refworld.org/docid/3fe6c7b54.html>

EUROPEAN COURT OF HUMAN RIGHTS. Case of Al-adsani v. the United kingdom (Application no. 35763/97). Judgment, 21 November 2001. Disponível em: <http://hudoc.echr.coe.int/sites/eng/pages/search.aspx?i=001-59885>

EUROPEAN COURT OF HUMAN RIGHTS. Case of Fogarty v. the United Kingdom (Application no. 37112/97). Judgment, 21 November 2001. Disponível em: <http://hudoc.echr.coe.int/sites/eng/pages/search.aspx?i=001-59886>

FASSBENDER, B. The meaning of international constitutional law. In: TSAGOURIAS, N. Transnational constitutionalism: international and european models. Cambridge: Cambridge University Press, 2007. p. 307-328.

FEDERAL HIGH COURT OF GERMANY. Jurisdiction over Yugoslav Military Mission Case. Germany, $1962 . \quad$ Disponível em: 
<http://www.utexas.edu/law/academics/centers/transnational/work_new/german/case .php?id=596>

FERRAJOLI, L. A soberania no mundo moderno: nasccimento e crise do Estado nacional. São Paulo : Martins Fontes, 2002.

FERREIRA, P. G. Responsabilidade Internacional do Estado. In: LIMA JR., J. B. Direitos Humanos Internacionais: avanços e desafios no início do século XXI. Recife: Movimento Nacional de Direitos Humanos, Regional Nordeste (MNDH - NE), 2001.

FIRENZE COURT OF CASSATION. Gutierres ex parte Bey di Tunisi v. Emilik, Cass. Firenze, 1886.

FOCARELLI, C. International Decisions: Federal Republic of Germany V. Giovanni Mantelli and others: Deportation--forced labor--international crimes--jus cogens--state immunity in civil proceedings--tort excep-tion--commercial exception. American Journal of International Law, n. 103, p. 122, January 2009.

FOX, H. The law of state immunity. Oxford: Oxford University Press, 2002.

GARCIA, M. Imunidade de jurisdição e o judiciário brasileiro. Brasília: CEDI, 2002.

GAUDREAU, J. Immunité de l'État et violation des droits de la personne: Une approche jurisprudentielle. Paris: HEI Publications, 2005.

GERMAN CONSTITUTIONAL COURT. Empire of Iran Case. BVerfGE 16, 272 BvM 1/62. Germany, 30 April 1963. Disponível em: $<$ http://www.utexas.edu/law/academics/centers/transnational/work_new/german/case .php?id=595>

GERMAN FEDERAL SUPREME COURT. The Distomo Massacre Case (Greek Citizens v. Federal Republic Of Germany). In: American Society of International Law, International Legal Materials, Vol. 42, No. 5, 2003, pag. 1030-1055. Disponível em: <http://www.jstor.org/stable/20694407> 
GOMES, C. A. A evolução do conceito de soberania : tendências recentes. Scientia luridica, p. 185-212, Jul./Dez. 1998.

GOMES, P. P. J. Direito Constitucional em evolução: perspectivas. Curitiba: Juruá, 2005.

GONZALEZ, C. J. D.; RODRíGUES, L. I. S.; MARIA, P. A. S. D. S. Curso de derecho internacional publico. Madrid: Editorial Civitas, 1998.

GOUVEIA, J. B. Direito Internacional Penal: Uma perspectiva dogmática-crítica. Coimbra: Almedina, 2008.

HAFNER, G.; ULRIKE, K. The United Nations Convention on jurisdictional immunities of states and their property. Netherlands Yearbook of International Law, v. XXXV, p. 3-49, December 2004.

HAFNER, GERHARD. State Immunity and the New U.N. Convention. In: Chatham House Conference 5 October 2005. Disponível em: http: $</ /$ www.chathamhouse.org/publications/papers/view/108110>

HAGUE COURT OF APPEAL. Case of N.V. Cabolent v. National Iranian oil. (1968). International Legal Materials, v. 9, № 1, pp. 152-163, January 1970.

HELLENIC SUPREME COURT OF CIVIL AND PENAL LAW. Prefecture of Voiotia v. Federal Republic of Germany. Greece, 2007. International Law Reports, V. 129, p. 514 et seq.

HIGH COURT OF NEW ZEALAND. Marine Steel Ltd v. Government of the Marshall Islands. New Zealand, 1981. International Law Reports, v. 64, p. 539 et seq.

Marine Steel Ltd v. Government of the Marshall Islands. New Zealand, 1982. International Law Reports, v. 64, p. 562 et seq.

HOUSE OF LORD. I Congreso del Partido. England, 1983. Disponível em: <http://swarb.co.uk/lisc/Inten19801984.php> 
Rahimtoola, appellant v. Nizam of Hyderabad and Another,

respondents.

Paquistão,

1957.

Disponível

em:

http://www.uniset.ca/other/css/1958AC379.html>

Jones v. Ministry of Interior of the Kingdom of Saudi Arabia.

United

Kingdom,

2006.

Disponível

em:

<http://www.publications.parliament.uk/pa/ld200506/ldjudgmt/jd060614/jones.pdf>

. Regina v. Bow Street Metropolitan Stipendiary Magistrate and Others, ex parte Pinochet Ugarte (no. 3). [2000] 1 A.C. 147. Disponível em: <http://www.uniset.ca/other/cs5/2000AC147.html>

HUMES-SCHULZ, S. Note: Limiting Sovereign Immunity in the Age of Human Rights. Harvard Human Rights Journal, n. 21, p. 105, Winter 2008.

INSTITUTE OF INTERNATIONAL LAW. The Protection of Human Rights and the Principle of Non-intervention in Internal Affairs of States. (Session of Santiago de Compostela - 1989) art 1ํ. Disponível em: <http://www.idiiil.org/idiE/resolutionsE/1989_comp_03_en.PDF>

Universal criminal jurisdiction with regard to the crime of genocide, crimes against humanity and war crimes. (Krakow Session - 2005). Disponível em: <http://www.idi-iil.org/idiE/resolutionsE/2005_kra_03_en.pdf>

INTERNATIONAL COMMITTEE OF THE RED CROSS. Customary International Humanitarian Law- Volume I: Rules. Editado por Jean-Marie Henckaerts e Louise Doswald-Beck. Cambridge: Cambridge University Press, 2005.

Geneva Convention Relative to the Treatment of Prisoners of War. 12 August $1949 . \quad$ Disponível em: <http://www.refworld.org/docid/3ae6b36c8.html>

INTERNATIONAL COURT OF JUSTICE. Ahmadou Sadio Diallo (Republic of Guinea v. Democratic Republic of the Congo), Merits, Judgment, I.C.J. Reports 2010. 
Application for Permission to Intervene by the Government of the Hellenic Republic. General List № 143, 13 January 2011. Disponível em: $<$ http://www.icj-cij.org/docket/files/143/16304.pdf>

Arrest Warrant of 11 April 2000 (Democratic Republic of the Congo v. Belgium). Disponível em:

$<$ http://www.icjcij.org/docket/index.php?p1=3\&p2 $=3 \&$ case $=121 \& p 3=4>$

Arrest Warrant of 11 April 2000 (Democratic Republic of the Congo v. Belgium). Dissenting opinion of Judge Al-Khasawneh. Disponível em: <http://www.refworld.org/docid/3fe6c7b54.html >

Arrest Warrant of 11 April 2000 (Democratic Republic of the Congo v. Belgium). Joint separate opinion of Judges Higgins, Kooijmans and Buergenthal. Disponível em: <http://www.icjcij.org/docket/index.php?p1=3\&p2=3\&case $=121 \& p 3=4>$

- Barcelona Traction, Light and Power Company, Limited (Belgium v. Spain) (New Application: 1962). Disponível em: <http://www.icjcij.org/docket/index.php?p1=3\&p2=3\&code=bt2\&case $=50 \& k=1$ a $>$

- Case concerning Jurisdictional Immunities of the State (Germany v. Italy) counter-memorial of Italy. 22 December 2009. Sec. IV, 1.13. Disponível em: $<$ http://www.icj-

cij.org/docket/index.php?p1=3\&p2=3\&k=60\&case=143\&code=ai\&p3=11> . Jurisdictional Immunities of the State (Germany $\mathbf{v}$ Italy). The Hague, Netherlands, 2008. Disponível em: < http://www.icjcij.org/docket/index.php?p1=3\&p2=3\&case $=143 \&$ code $=a i \& p 3=0>$

Jurisdictional Immunities of the State (Germany v. Italy: Greece intervening). Dissenting opinion of Judge Cançado Trindade. Judgment of 3 February 2012. Disponível em: <http://www.icjcij.org/docket $/$ index.php?p1=3\&p2=3\&case $=143 \&$ code $=a i \& p 3=4>$ 
Jurisdictional Immunities of the State (Germany v. Italy: Greece intervening). Judgment, I.C.J. Reports 2012, p. 99. Disponível em: $<$ <ttp://www.icj-cij.org/docket/files/143/16883.pdf>

Legal Consequences for States of the Continued Presence of South Africa in Namibia (South West Africa) notwithstanding Security Council Resolution 276 (1970). Advisory Opinion of 21 June 1971 Disponível em: $<$ http://www.icj-

cij.org/docket/?sum $=296 \&$ code $=$ nam $\& p 1=3 \& p 2=4 \&$ case $=53 \& k=a 7 \& p 3=5>$

Military and Paramilitary Activities in and against Nicaragua (Nicaragua v. United States of America). Judgment of 27 June 1986. Disponível em: <http://www.icj-cij.org/docket/index.php?sum=367\&p1=3\&p2=3\&case=70\&p3=5>

Rules of court. 1978. Disponível em: <http://www.icjcij.org/documents/index.php?p1=4\&p2=3\&p3=0>

The Hague Conference (2010). Draft Declaration of International Law Principles on Reparation for Victims of Armed Conflict (Substantive Issues). Disponível em: <http://www.ilahq.org/en/committees/index.cfm/cid/1018>

Draft Articles on Responsibility of States for Internationally Wrongful Acts. Suplement №. 10 (A/56/10), chp.IV.E.1November 2001. Disponível em: <http://www.refworld.org/docid/3ddb8f804.html>

JORGENSEN, N. H. B. The responsibility of states for international crimes. Oxford: Oxford University Press, 2000.

JORNAL OFICIAL DA UNIÃO EUROPEIA. Tratado que estabelece uma Constituição para a Europa. Comunicações e Informações. 2004/C 310/01. Disponível em: $<$ http://eurlex.europa.eu/LexUriServ/LexUriServ.do?uri=OJ:C:2004:310:FULL:PT:PDF> JUSTIÇA DO TRABALHO. Consulado Geral do Japão v. Ribeiro de Lima. Brasil, 2002. Disponível em: 
<http://bd1.trt1.jus.br/xmlui/bitstream/handle/1001/12718/00528005819955010056\% 2330-08-2006. pdf?sequence $=1>$

KANT, I. A paz perpértua e outros opúsculos. Lisboa: Edições 70, 2009. Fundamentação da metafísica dos costumes: texto integral. Porto : Areal, 2005.

KLABBERS, J.; PETERS, A.; ULFSTEIN, G. The constitutionalization of international law. New York: Oxford University Press, 2009.

KNUCHEL, S. State Immunity And The Promise Of Jus Cogens. Northwestern Journal of International Human Rights, v. 9, p. 149-183, 2011.

LAUTERPACHT, H. The Problem of Jurisdictional Immunities of Foreign States. British Year Book of International Law, v. 28, p. 220-272, 1951.

LEVI, J. A. As Between Princz and King: Reassessing the Law of Foreign Sovereign Immunity as Applied to Jus Cogens Violators. The Georgetown Law Journal, v. 86, p. 2703-2734, 1997-1998.

LIN, K. Note: Limiting Sovereign Immunity in the Age of Human Rights. Columbia Law Review, n. 108, p. 1718, November 2008.

LUÑO PÉREZ, A. E. Temas clave de la Constitucion Espanõla: Los derechos fundamentales. 5. ed. Madrid: Tecnos, 1993.

MACHADO, J. Direito internacional: do paradigma clássico ao pós-11 de Setembro. Coimbra: Coimbra Editora, 2006.

MAdRuga FILHO, A. A Renúncia À Imunidade de Jurisdição Pelo Estado Brasileiro e o Novo Direito da Imunidade de Jurisdição. Rio de Janeiro: Renovar, 2003.

MADURO, M. P. Europe and the constitution: what if this is a good as it gets? In: WEILER, J. H. H.; WIND, M. European constitutionalism: beyond the state. Cambridge: Cambridge University Press, 2003. p. 74-102. 
MCCORQUODALE, R. Impact on State Responsability. In: KAMMINGA, M. T.; SCHEININ, M. The impact of human rights law on general international law. Oxford ; New York: Oxford University Press, 2009. p. 235-254.

MCGREGOR, L. State Immunity and Jus Cogens. International and Comparative Law Quarterly, v. 55, p. 437-446, April 2006.

MELO, C. D. D. A. Direitos humanos e conflitos armados. Rio de Janeiro: Renovar, 1997.

METCALF, K. Note: reparations for displaced torture victims. Cardozo Journal of International and Comparative Law, n. 19, p. 451, Spring 2011.

MIRANDA, J. Curso de direito internacional público. $4^{\underline{a}}$ ed. rev. e actualiz. ed. Parede: Princípia, 2009.

MONETA, FRANCESCO. State Immunity for International Crimes: The Case of Germany versus Italy before the ICJ: Jurisdictional Immunities of the State (Germany v. Italy). The Hague Justice Portal, 2009. Disponível em: < http://www.haguejusticeportal.net/index.php?id=10751>

MORIKAWA, M. M. Deslocados internos: entre a soberania do Estado e a protecção internacional dos Direitos do Homem : uma crítica ao sistema internacional de protecção dos refugiados. Coimbra: Coimbra Editora, 2006.

MULTI-MEMBER COURT OF LEVADIA. Case No. 137/1997, Distorno Massacre. 30 Oct. 1997. Revue Hellenique de droit international, v. 50, p. 599 et seq, 1997.

NAPLES COURT OF CASSATION. Typaldos v. Manicomio di Aversa, Cass. Napoli, 1886.

NGUYÊN, Q. D.; DAILLIER, P.; PELLET, A. Direito internacional público. Lisboa: Fundação Calouste Gulbenkian, 2003.

NUNES, P. Dicionário de tecnologia jurídica. 13ª . ed. Rio de Janeiro: Renovar, 1999.

O'BRIEN, J. International law. London [etc.]: Cavendish Publishing, 2002. 
O'KEEFE, R. SYMPOSIUM: FOREIGN STATE IMMUNITY AT HOME AND ABROAD: State Immunity and Human Rights: Heads and Walls, Hearts and Minds. Vanderbilt Journal of Transnational Law, v. 44, p. 999-1045, October 2011.

ORAKHELASHVILI, A. State Immunity and Hierarchy of Norms: Why the House of Lords Got It Wrong. European Journal of International Law, v. 18, n. 5, p. 955-970, 2007.

ORGANIZAÇÃO DAS NAÇÕES UNIDAS. Convenção de Viena sobre o Direito dos Tratados, assinada em 23 de Maio de 1969. Disponível em: <http://www.gddc.pt/siii/im.asp?id=1588>

. Preâmbulo do Estatuto de Roma do Tribunal Penal Internacional. Disponível em: <http://www.dhnet.org.br/direitos/sip/tpi/esttpi.htm>

PASTOR RIDRUEJO, J. A. El proceso de internacionalización de los derechos humanos. El fin del mito de la soberanía nacional (I). Plano Universal: La obra de las Naciones Unidas. In: Consolidación de derechos y garantías: los grandes retos de los derechos humanos en el siglo XXI: seminario conmemorativo del 50 aniversario de la Declaración universal de los derechos humanos. Madrid: 1999.

. Una estrategia integrada para la proteccíon internacional de los derechos humanos. In: Héctor Gros Espiell: amicorum liber : persona humana y derecho internacional. Bruxelles: Bruylant, v. 2, 1997.

PAUWELYN, J. Conflict of norms in public international law: how WTO law relates to other rules of international law. Cambridge : Cambridge University Press, 2003.

PERMANENT COURT OF INTERNATIONAL JUSTICE. case concerning the factory at Chorzów Merits, julgamento de 13 de Set. de 1928, P.C.I.J. Series A. Disponível em: < http://www.icj-cij.org/pcij/series-a.php?p1=9\&p2=1>

Case concerning the factory at Chorzów (Jurisdiction), Judgment. 26 July 1927, P.C.I.J. Series A. Disponível em: < http://www.icjcij.org/pcij/series-a.php?p1=9\&p2=1> 
. Case S.S. Wimbledom, P.C.I.J Series A, № 1, Julgamento de 17

August 1923. Disponível em: < http://www.icj-cij.org/pcij/series-a.php?p1=9\&p2=1> Judgment of 30 August 1924. Case Mavrommatis Palestine concessions. PCIJ Series A, n. 2. Disponível em: <http://www.icj-cij.org/pcij/seriesa.php?p1 $=9 \&$ 2 $2=1>$

PETSCHE, M. Jus Cogens as a vision of the International Legal Order. Penn State International Law Reports, v. 29, p. 233-273, 2010-2011.

PIOVESAN, F. Direitos Humanos e o Direito Constitucional Internacional. São Paulo: Saraiva, 2010.

POTESTA, M. The Alien Tort Statute: Comments on Current Issues: B. Immunity and Notable Preliminary Issues: State Immunity and Jus Cogens Violations: The Alien Tort Statute Against the Backdrop of the Latest Developments in the Law of Nations. Berkeley Journal of International Law, v. 28, p. 571 et seq, 2010.

PRIVY COUNCIL OF THE UNITED KINGDOM. The Philippine Admiral, England, 1975.

QUEBEC COURT OF APPEAL. Venne v. Democratic Republico of Congo. Canada, 1968.

QUEENSLAND SUPREME COURT. USA v. Republic of China. Australia. International Law Reports, v. 17, p. 168 et seq.

QUEIROZ, C. Direito Constitucional Internacional. Lisboa: Coimbra Editora, 2011.

RAGAZZI, M. The concept of international obligations Erga Ommes. Oxford: Clarendon Press, 1997.

RAMOS, A. D. C. Responsabilidade Internacional do Estado por Violação de Direitos Humanos. Revista CEJ, Brasília, n. 29, p. 53-63, abr.jun 2005.

- Responsabilidade internacional por violações de Direitos Humanos: seus elementos, a reparação devida e sanções possíveis: teoria e prática do direito internacional. Rio de Janeiro: Renovar, 2004. 
RATNER, S. R.; ABRAMS, J. S.; BISCHOFF, J. L. Accountability for human rights atrocities in international law: beyond the Nuremberg legacy. 3a. ed. Oxford ; New York: Oxford University Press, 2009.

REZEK, J. F. Direito internacional público: curso elementar. 7ª̣. ed. São Paulo: Saraiva, 1998.

Direito internacional público: curso elementar. 9ª . ed. São Paulo: Saraiva, 2002.

ROSENTOCK, R. The ILC and State Responsability. American Journal of International Law, v. 96, n. 4, p. 792-856, 2002.

SALCEDO, J. A. C. Reflections on the Existence of a Hierarchyof Norms in International Law. European Journal of International Law, p. 583-595, 1997.

SCISO, E. Italian Judges' Point of View on Foreign States' Immunity. Vanderbilt Journal of Transnational Law, v. 44, p. 1201-1231, 2011.

SENA, P. D.; VITTOR, F. D. State Immunity and Human Rights: The Italian Supreme Court Decision on the Ferrini Case. The European Journal of International Law, v. 16, n. 1, p. 89-112, 2005.

SHAW, M. N. International law. 5th. ed. Cambridge: Cambridge University Press, 2003.

SILVA, J. A. D. Curso de Direito Constitucional Positivo. 22. ed. São Paulo: Malheiros Editores, 2003.

SINCLAIR, S. I. The Law of Sovereign Immunity: Recent Developments. Recueil des Cours de I'Académie de Droit International de La Haye, v. 167, p. 121-217, 1980.

SINGAPORE HIGH COURT. The Hai Hsuan. Singapore, 1950. International Law Reports, v. 17, p. 170.

SLAUGHTER, A.-M. Security, Solidarity, And Sovereignty: The Grand Themes Of Un Reform. The American Journal Of International Law, v. 99, p. 619-631, 2005. 
SOARES, G. F. D. S. Origens e justificativas da imunidade de jurisdição. In: MADRUGA, A. P. F.; GARCIA, M. Imunidade de jurisdição e o judiciário brasileiro. Brasília: CEDI, 2002.

SOUTH-AFRICA SUPREME COURT. Inter-Science v. Moçambique, 1979. International Law Reports, v. 64, pp. 689 et seq., January 1983.

Kaffraria Property Co. (Pty) Ltd. v. Government of the Republic of Zambia, 1980. South African Law Reports, v. 2, pp. 709 et eq.

STEPHAN, P. B. Foreign State Immunity at home and abroad: The Political Economy of Jus Cogens. Vanderbilt Journal of Transnational Law, n. 44, p. 1073, October 2011.

STEWART, D. P. International Decisions: Jurisdictional Immunities of the State (Germany v. Italy; Greece Intervening). American Journal of International Law, v. 106, p. 609 et seq, 2012.

SUPREME COURT JUDGMENTS. Gouvernement de la République Démocratique du Congo v. Venne, Canada, 1971. Disponível em: < http://scccsc.lexum.com/decisia-scc-csc/scc-csc/scc-csc/en/item/4952/index.do>

Re Canada Labour Code. Canada, 1992. Disponível em: <http://scc-csc.lexum.com/decisia-scc-csc/scc-csc/scc-csc/en/item/880/index.do>

SUPREME COURT NEW SOUTH WALES. Grunfeld v. United States of America. Australia, 1968. International Law Reports, v. 52, p. 332 et seq.

SUPREME COURT OF CASSATION OF ITALY. Ferrini v Germany, Appeal decision. №. 5044/4; ILDC 19 (IT 2004). 11 March 2004. Disponível em: <http://www.geneva-academy.ch/RULAC/pdf_state/Ferrini.pdf>

SUPREME COURT OF DENMARK. Embassy of the Socialist Republic of Czechoslovakia v. Jens Nielsen Bygge-Entrepriser. Denmark, 1982. International Law Reports, v. 78 , p. 81 et seq.

SUPREME COURT OF INDIA. Harbhajan Singh Dhalla vs Union Of India. India, 1986. Disponível em: < http://indiankanoon.org/doc/1753789/> 
SUPREME COURT OF ISRAEL. Her Majesty the Queen in Right of Canada v. Edelson and ors. Israel, 1997. Disponível em: < http://opil.ouplaw.com/view/10.1093/law:ildc/577il97.case.1/law-ildc-577il97>

SUPREME COURT OF LITHUANIA. Stukonis v. United States Embassy, 5 January 1998, Baltic Yearbook of International Law, v. 2, pp. 270 et seq., 2002

SUPREME COURT OF MALAYSIA. Commonwealth of Australia v. Midford (Malaysia) Sdn Bhd and Another. Malaysia, 1990. International Law Reports, v. 86, p. 640 et seq.

SUPREME COURT OF PAKISTAN. Qureshi v. Union of Soviet Socialist Republics. Pakistan, 1981. International Law Reports, v. 64, p. 585 et seq.

SUPREME COURT OF SPAIN. Emilio BM v. Embassy of Equatorial Guinea. Spain, 1986. International Law Reports, v. 86, p. 508 et seq.

SUPREME COURT OF THE NETHERLANDS. Société Européenne v. Yugoslavia, 26 October 1973. International Law Reports, v. 65, pp. 356 et seq., January 1984.

SUPREME COURT OF THE PHILIPPINES. Harry Lyons v. USA. International Law Reports, v, 88, p. 711 et seq.

SUPREME COURT OF THE UNITED STATES. Saudi Arabia et al v. Nelson et ux. United States of America, 1993. Disponível em: <http://www.law.cornell.edu/supct/html/91-522.ZS.html>

SUPREME COURT OF ZIMBABWE. Barker McCormac Ltd v. Government of Kenya, Zimbabwe, 1983. International Law Reports, v. 84, p. 18 et seq.

SUPREME COURT. Soviet Republic Case. Greece, 1928.

SUPREMO TRIBUNAL DE JUSTIÇA. X v. Israel. Portugal, 2002. Disponível em: <http://www.dgsi.pt/jstj.nsf/954f0ce6ad9dd8b980256b5f003fa814/e3c456304a4ca0ce 80256c7600364ddc?OpenDocument> 
SUPREMO TRIBUNAL FEDERAL. Consulado Geral do Japão v. Ribeiro, Brasil, 2002.

Disponível

em:

$<$ http://redir.stf.jus.br/paginadorpub/paginador.jsp?docTP=AC\&doclD=331821>

Représentation commerciale da RDA. Brasil, 1989. Disponível em:

$<$ http://eurlex.europa.eu/Notice.do?mode=dbl\&lang=pt\&ihmlang=pt\&lng1=pt,fr\&lng2= da,de,el,en,es,fi,fr,it,nl,pt,sv,\&val=221711:cs>

República Árabe da Síria v. República Federal do Egito, Brasil,

1982.

Disponível

em:

<http://jurisprudencia.s3.amazonaws.com/STF/IT/ACO_298_DF_1278816775219.pdf ?Signature=hnF39gBFw4feSoA6j60QJtd8ZHs\%3D\&Expires=1387675906\&AWSAcc essKeyld=AKIAIPM2XEMZACAXCMBA\&response-content-type=application/pdf>.

SUY, E. Immunity of States before Belgian Courts and Tribunals. Heidelberg Journal of International Law, v. 27, p. 660-692, 1967.

SWISS FEDERAL COURT. Dreyfus. Switzerland, 1918.

TESÓN, F. R. A Philosophy of International Law. Boulder: Westview Press, 1998.

THEODORO JÚNIOR, H. Curso de Direito Processual Civil. 41. ed. Rio de Janeiro: Forense, v. 1, 2005.

TOMUSCHAT, C. Symposium: Foreign State Immunity at home and abroad: The International Law of State Immunity and Its Development by National Institutions. Vanderbilt Journal of Transnational Law, n. 44, p. 1105.

TOUFAYAN, M. A Return to Communitarianism? Reacting to "Serious Breaches of Obligations Arising under Peremptory Norms of General International Law under the Law of State Responsibility and United Nations Law. The Canadian Yearbook of International Law, p. 197-251, 2004.

TOYNBEE, A. Um estudo de história. Lisboa: Editora Ulisseia, 1964.

TRIBUNAL DA RELAÇÃO DE LISBOA. A v. Embaixada da Áustria (R.). Agravo n. 4107/2005-4. Portugal, 21. set. 2005. Disponível em: 
<http://www.dgsi.pt/jtrl.nsf/33182fc732316039802565fa00497eec/98cff20fb559315b8 025709f0033c537?OpenDocument>

HM, S.A. (A.) v. Embaixada da República de X (R.). Portugal, 2011. Disponível

em: <http://www.coe.int/t/dlapil/cahdi/Source/state_immunities/Portugal_2013_Caselaw9. pdf>

TRINDADE, A. A. C. A humanização do direito internacional. Belo Horizonte: Del Rey, 2006.

. O direito internacional em um mundo em transformação: ensaios, 1976-2001. Rio de Janeiro; São Paulo: Renovar, 2002.

. Os rumos do direito internacional contemporâneo: de um jus inter gentes a um novo jus gentium no século XXI. In: TRINDADE, A. A. C. O direito internacional em um mundo em transformação: ensaios, 1976-2001. São Paulo: Renovar, 2002. p. 1041-1109.

The Access of Individuals to International Justice. New York:

Oxford University Press, 2011.

. Tratado de direito internacional dos direitos humanos. Porto Alegre: Sérgio Antonio Fabris Editor, v. II, 1999.

A constitucionalização do Direito internacional: mito ou realidade?

Revista de Informação Legislativa, Brasília, p. 271-284, abr./jun. 2008.

TROOBOFF, P. Foreign State Immunity: Emerging Consensus on Principles. Recueil des Cours Collected Courses of The Hague Academy of International Law, v. 200, p. 252-274, 1986.

UNITED NATIONS. A/C.6/54/L.12. U.N. Chairman of the Working Group, Convention on jurisdictional immunities of States and their property. 12 November 1999. Disponívem em: <http://www.un.org/law/cod/sixth/54/summary.htm>

A/C.6/47/L.10. Report of the Working Group, 1992. Disponível em: <http://legal.un.org/ilc/documentation/english/A_46_10.pdf> 
A/C.6/48/L.4. Report of the Working Group, 1993. Disponível em: $<$ http://daccess-ddsny.un.org/doc/UNDOC/LTD/N93/627/30/PDF/N9362730.pdf?OpenElement> A/C.6/48/SR.29. General Assembly Official Records. Forty-eighth Session, Summary Record of the 29th meeting, 15 November 1993, Disponível em: $<$ http://daccess-ddsny.un.org/doc/UNDOC/GEN/N93/823/91/PDF/N9382391.pdf?OpenElement> A/C.6/49/L.2. Report of the Chairman of the informal consultations held in the Sixth Committee, Part II, 1994. Disponível em: < http://legal.un.org/ilc/summaries/4_1.htm>

A/C.6/49/SR.32. General Assembly Official Records, Forty-ninth Session, Summary Record of the 32nd meeting, 11 November 1994. Disponível em: $<$ http://daccessddsny.un.org/doc/UNDOC/GEN/N94/822/20/PDF/N9482220.pdf?OpenElement>

A/C.6/49/SR.7. General Assembly Official Records, Forty-ninth Session, Summary Record of the 7th meeting, 6 October 1994, Disponivel em:<http://unbisnet.un.org:8080/ipac20/ipac.jsp?session=1TO4B91372338.14674\&m enu $=$ search \&aspect $=$ subtab $124 \& n p p=50 \& i p p=20 \& s p p=20 \&$ profile $=$ bib $\&$ ri $=2 \&$ source $=$ \%21 horizon\&index=.UD\&term=A\%2FC.6\%2F49\%2FSR.7\&x=1\&y=8\&aspect=subta b124>

A/C.6/54/L.12. Chairman of the Working Group, Report: Convention on Jurisdictional Immunities of States and their Property. 12 November 1999. Disponível em: <http://www.un.org/law/cod/sixth/54/summary.htm>

A/CN.4/L.283. Yearbook of the International Law Commission: 1978, vol. II(2). Report of the Working Group on review of the multilateral treatymaking process. Report of the Working Group. Disponível em: <http://legal.un.org/ilc/publications/yearbooks/Ybkvolumes(e)/ILC_1978_v2_p2_e.pdf $>$

A/CN.4/SER.4/1976/Add. 1 (Part 2). Yearbook of the International Law Commission. Vol. II, Part Two, 1976. Report of the Commission to the General 
Assembly on the work of its twenty-eighth session. Disponivel em: <http://legal.un.org/ilc/publications/yearbooks/1976.htm>

A/CN.4/SER.A/1966/Add.I. Yearbook of The International Law Commission. vol. II, $1966 . \quad$ Disponível em: <http://legal.un.org/ilc/publications/yearbooks/Ybkvolumes(e)/ILC_1966_v2_e.pdf>

A/CN.4/SER.A/1999/Add.1 (Part 2). Report of the Working Group on Jurisdictional Immunities of States and Their Property, U.N. Disponível em: <http://legal.un.org/ilc/publications/yearbooks/Ybkvolumes(e)/ILC_1999_v2_p2_e.pdf $>$

A/RES/32/151, Resolutions adopted by the General Assembly during its Thirty-second Session, 19 December 1977. Disponível em: <http://www.un.org/documents/ga/res/32/ares32.htm>

A/RES/39/46. General Assembly, Convention against Torture and Other Cruel, Inhuman or Degrading Treatment or Punishment: resolution / adopted by the General Assembly, 10 December 1984. Disponível em: <http://www.refworld.org/docid/3b00f2224.html>

A/RES/46/54. Resolutions adopted by the General Assembly at its 46th session, 2002. Disponível em: <http://www.un.org/depts/dhl/resguide/r46_en.shtml>

A/RES/46/55. Resolutions adopted by the General Assembly at its 46th session. Disponível em: <http://www.un.org/depts/dhl/resguide/r46_en.shtml>

A/RES/60/147. Basic Principles and Guidelines on the Right to a Remedy and Reparation for Victims of Gross Violations of International Human Rights Law and Serious Violations of International Humanitarian Law. Resolution adopted by the General Assembly, 21 March 2006. Disponível em: $<$ http://www.refworld.org/docid/4721 cb942.html>

. A/RES/60/147. Preambulo da Assembléia Geral. Disponível em: <http://www.un.org/Docs/asp/ws.asp?m=A/RES/60/147> 
Convention on Jurisdictional Immunities of States and Their Property: Declarations and Reservations. New York, 2 December 2004. Disponível em: <https://treaties.un.org/Pages/ViewDetails.aspx?mtdsg_no=III$13 \&$ chapter $=3 \&$ lang $=$ en $>$

Document $\mathrm{A} / \mathrm{CN} \cdot \mathbf{4 / 5 0 7}$. Third report on State responsibility. International Law Commission Fifty-second session. 15 March 2000. Disponível em: $<$ http://daccess-dds-

ny.un.org/doc/UNDOC/GEN/N00/345/10/PDF/N0034510.pdf?OpenElement>

Document. A/46/10. Yearbook of the International Law Commission: 1991, vol. II(2). Report of the International Law Commission on the work of its forty-third session, 29 April-19 July 1991. Official Records of the General Assembly, Forty-sixth session, Suplement No. 10. Disponível em: $<$ http://legal.un.org/ilc/documentation/english/A_46_10.pdf>

Document: A/CN.4/1/Rev.1. Survey of International Law in Relation to the Work of Codification of the International Law Commission: Preparatory work within the purview of article 18, paragraph 1 , of the of the International Law Commission - Memorandum submitted by the Secretary-General. Disponível em: <http://legal.un.org/ilc/documentation/english/a_cn4_1_rev1.pdf>

Draft Articles on Responsibility of States for Internationally Wrongful Acts. Resolution 56/83 of 12 December 2001, and corrected by document A/56/49. Disponível em: <http://legal.un.org/avl/ha/rsiwa/rsiwa.html>

Estate of Jean-Baptiste Caire (France) v. United Mexican States. Reports of International Arbitral Awards, volume 7, June 1929. Disponível em:< http://legal.un.org/riaa/cases/vol_V/516-534_Caire.pdf>

Geneva Convention on the High Seas. Adopted at Geneva, Switzerland on 29 April 1958. Disponível em: $<$ http://treaties.un.org/pages/ViewDetails.aspx?src=TREATY\&mtdsg_no=XXI2\&chapt er $=21$ \&lang $=$ en $>$ 
Report of the International Commission of Inquiry on Darfur to the United Nations Secretary-General. Geneva, 25 January 2005. Disponível em: $<$ http://www.un.org/news/dh/sudan/com_inq_darfur.pdf>

S/RES/0662 (1990). RESOLUTION 662 (1990). Adopted by the Security Council at its 2934th meeting on 9 August 1990. Diponível em: <http://www.fas.org/news/un/iraq/sres/sres0662.htm>

S/RES/418 (1977). Resolution 418 (1977). Adopted by the Security Council at its 2046th meeting, on 4 November 1977, 4 November 1977. Diponível em: <http://www.refworld.org/docid/3b00f16e30.html>

S/RES/569 (1985). Resolution 569 (1985) Adopted by the Security Council at its 2602nd meeting, on 26 July 1985, 26 July 1985. Disponível em: < http://www.refworld.org/docid/3b00f1651c.html>

Statute of the International Law Commission. Adopted by the General Assembly in resolution 174 (II) of 21 November 1947, as amended by resolutions 485 (V) of 12 December 1950, 984 (X) of 3 December 1955, 985 (X) of 3 December 1955 and $36 / 39$ of 18 November 1981. Disponível em: $<$ http://legal.un.org/ilc/texts/instruments/english/statute/statute_e.pdf>

Summaries of Judgments, Advisory Opinions and Orders of the International Court of Justice. 2008 - 2012. Immunities of the State (Germany v. Italy). Counter-claim. Order of 6 July 2010. Disponível em: $<$ http://www.un.org/law/ICJsummaries/>

Supplement № 10. A/32/10. Report of the International Law Commission on the work of its twenty-ninth session, 9 May - 29 July 1977, Official Records of the General Assembly, Thirty-second session. Disponível em: $<$ http://legal.un.org/ilc/sessions/29/29sess.htm>

Supplement No. $10 \mathrm{~A} / \mathbf{6 1 / 1 0}$. Report on the work of its fifty-eighth session. 1 May to 9 June and 3 July to 11 August 2006. Disponível em: <http://legal.un.org/ilc/reports/2006/2006report.htm> 
Supplement No. 49 (A/59/49), United Nations Convention on Jurisdictional Immunities of States and Their Property. Adopted by the General Assembly of the United Nations on 2 December 2004. Official Records of the General Assembly, Fifty-ninth Session, Disponível em: <http://untreaty.un.org/ilc/texts/instruments/english/conventions/4_1_2004.pdf>

Treaty of Peace with Italy. Paris, 1947. Disponível em: <http://www.istrianet.org/istria/history/1800-present/ww2/1947_treaty-italy.htm>

\section{United Nations Convention on Jurisdictional Immunities of}

States and Their Property. Adopted by the General Assembly of the United Nations on 2 December 2004. Official Records of the General Assembly, Fifty-ninth Session, Supplement No. $49 \quad$ (A/59/49). Disponível em: <http://untreaty.un.org/ilc/texts/instruments/english/conventions/4_1_2004.pdf>

United Nations Convention on the Law of the Sea of 10 December 1982.

Disponível

em: $<$ http://www.un.org/depts/los/convention_agreements/convention_overview_conventi on.htm>

UNITED STATES CODE. Terrorism exception to the jurisdictional immunity of a foreign state. Disponível em: <http://www.law.cornell.edu/uscode/text/28/1605A>

UNITED STATES COURT OF APPEALS. Hugo Princz v. Federal Republic of Germany. 26 F.3d 1166, 307 U.S.App.D.C. 102. Disponível em: <http://iilj.org/courses/documents/princzv.germany.pdf>

. Ninth Circuit. Chuidian v. Philippine National Bank. 912 F.2d 1095. Aug. 29, 1990. Disponível em: <http://www.jstor.org/discover/10.2307/2203069?uid=3738880\&uid=2129\&uid=2\&uid $=70 \&$ uid $=4 \&$ sid $=21103151890881>$

Victory Transport Inc v. Comisaría General. New York, 1964. Disponível em: <http://www.leagle.com/decision/1964690336F2d354_1611> UNITED STATES HOUSE OF REPRESENTATIVES. Report №. 94-1487. 1976. Reprinted in: USCCAN 6604, 6606. 
UNITED STATES SUPREME COURT. Republic of Mexico v. Hoffman. In: Volume 324, $1945 . \quad$ Disponível em: <http://supreme.justia.com/cases/federal/us/324/30/case.html>

The Exchange v. McFaddon. In: Volume 11, 1812. Disponível em: $<$ http://supreme.justia.com/cases/federal/us/11/116/case.html>

UNITED STATES. 90 STAT. 2891 - Foreign Sovereign Immunities Act. 94th Congress, 2nd Session, 1976. Public Law 94-583. October, 1976. Disponível em: <http://www.gpo.gov/fdsys/granule/STATUTE-90/STATUTE-90-Pg2891/contentdetail.html>

VATTEL, E. D. O direito das gentes. Brasília: Editora Universidade de Brasília: Instituto de Pesquisa de Relações , 2004.

VIRALLY, M. Réflexions sur le "jus cogens. Annuaire français de droit international, p. 5-29, 1966.

VITORIA, F. D. Political writings: Cambridge Texts in the History of Political Thought. Cambridge: Cambridge University Press, 1995.

VOYIAKIS, E. Access to Court v. State Immunity. International and Comparative Law Quarterly, v. 52, p. 297-332, 2003.

WALKER, N. Postnational constitutionalism and the problem o translation. In: WEILER, J. H. H.; WIND, M. European constitutionalism: beyond the state. Cambridge: Cambridge University Press, 2003. p. 27-54.

WALTER, C. Constituzionalizing (Inter)national Governance - Possibilities for and Limits to the development of an Intenational Constitutional Law. German Yearbook of International Law, v. 44, p. 170-201, 2001.

WEISS, E. B. Invoking state responsability in the twenty-first century. American Journal of International Law, v. 96, n. 4, p. 798-816, 2002.

WET, E. D. The international constitutional order. International \& COmparative Law Quarterly, v. 55, n. 1, p. 51-76, 2006. 
WOOLF, C. N. S. Bartolus of Sassoferrato: his position in the history of medieval political thought. Cambridge: Cambridge University press, 1913.

WUERTH, I. Commentary: International Law in Domestic Courts and the jurisdictional immunities of the state case. Melbourne Journal of International Law, n. 13, p. 819, November 2012.

. Pinochet's Legacy Reassessed. American Journal of International Law, n. 106, p. 731, October 2012.

YANG, X. State Immunity in International Law. Cambridge: Cambridge University Press, 2012.

ZIMMERMANN, A. Sovereing Immunity and Violations of International Jus Cogens. Michigan Joural of International Law, v. 16, p. 433-440, 1994-1995. 